\title{
DISTRIBUIÇÃO DA VARIABILIDADE GENÉTICA E CARACTERIZAÇÃO ISOENZIMÁTICA DE ETNOVARIEDADES EM ROÇAS DE MANDIOCA (Manihot esculenta Crantz) DO BRASIL
}

\section{MARIA INEZ FERNANDES FARALDO}

Bióloga

Orientador: Prof. Dr. AKIHIKO ANDO

\begin{abstract}
Tese apresentada à Escola Superior de Agricultura "Luiz de Queiroz", Universidade de São Paulo, para obtenção do título de Doutor em Agronomia, Área de Concentração: Genética e Melhoramento de Plantas.
\end{abstract}

PIR A C I C A B A

Estado de São Paulo - Brasil

Julho - 1999 
Dados Internacionais de Catalogação na Publicação (CIP) DIVISĀO DE BIBLIOTECA E DOCUMENTAÇĀO - Campus "Luiz de Queiroz"/USP

\author{
Faraldo, Maria Inez Fernandes \\ Distribuição da variabilidade genética e caracterizaçāo isoenzimática de \\ etnovariedades em roças de mandioca / Maria Inez Fernandes Faraldo. - - \\ Piracicaba, 1999. \\ 117 p. : il. \\ Tese (doutorado) - E Escola Superior de Agricultura Luiz de Queiroz, 1999. \\ Bibliografia. \\ 1. Danâmica populacional 2. Domesticação vegetal 3. Germoplasma 4. \\ Isoenzima 5. Mandioca 6. Melhoramento genético vegetal 7. Variabilidade \\ genética 1 . Titulo
}

CDD 633.4 


\begin{abstract}
À memória do Prof. Paulo Sodero Martins. Ele foi mais do que um profissional de talento e respeito, um ser humano fascinante, atento aos mínimos detalhes a sua volta em busca de novas descobertas no campo da genética ecológica e evolução plantas.
\end{abstract}


À memória de meu pai. Dr. José Faraldo, líder inconteste da criação da Faculdade de Medicina - Unesp/Botucatu. À Maria de Lourdes Fernandes Faraldo, minha mãe, (mulher feito anjo).

Aos meus irmãos, Ana Lúcia, Luis Sérgio, Cláudia Regina, José Henrique, Solange Aparecida e Luis André. Às minhas sobrinhas Tatiana e Letícia Ao meu cunhado Tato. Às minhas cunhadas Lúcia e Rossana. 
"Todo aquele que se esmera em cumprir fielmente os seus deveres, preenche o fim para o qual foi criado e firma em si mesmo os princípios de um caráter elevado". 


\section{AGRADECIMENTOS}

- Agradeço à Deus pela fé e perseverança concedidas em todos os momentos.

- Aos professores do Departamento de Genética por ter apoiado a continuidade do trabalho do Prof. Paulo Sodero Martins, em especial ao Prof. Dr. Akihiko Ando por ter assumido a orientação da minha tese com desprendimento e confiança, em nome de uma amizade.

- Ao Prof. Dr. Paulo Sodero Martins (in memorium) pela oportunidade concedida, pela confiança depositada e sobretudo sabedoria transmitida; pelo exemplo de vida e profissional que nos deixou. Serei sempre grata.

- À Lourdinha, Ana Lúcia, Ana Cláudia e Ana Elisa pela maneira que sempre nos acolheram.

- Aos funcionários do Departamento de Genética da ESALQ/USP, em especial à Ronaldo José Rabello, pela colaboração prestada na condução dos trabalhos de laboratório, e auxilio nas coletas de material na Estação Experimental de Anhembi.

- Ao Prof. Dr. Roland Vencovsk e Alexandre M. Sebbenn, pela orientação e colaboração inestimável na análise estatística dos dados.

- À Prof. Dra. Elizabeth Ann Veasey e Prof. Carlos Giaveno, pela leitura criteriosa do manuscrito da tese e pelas sugestões.

- À Silvana Marchizelli Gregório e Aparecida Elizabeth dos Santos da Silva e Silvana Cristina Nascimento Oliveira, pela revisão da bibliografia, auxílio nos inúmeros levantamentos bibliográficos realizados, e principalmente pela atenção concedida e amizade. 
- À Elza Martins Ferraz do Laboratório de Biologia Reprodutiva e Genética de Espécies Arbóreas do Departamento de Ciências Florestais da ESALQ/USP, pela amizade e auxílio na determinação da metodologia de eletroforese.

- Ao Prof. Dr. João Lúcio de Azevedo pelo apoio, incentivo, oportunidades concedidas e pela amizade sempre presente.

- À Léia, Carmem e Adriana do Departamento de Genética pela amizade, convivência e atenção concedida.

- À Neusa Maria Sarto Rocha pela presteza na compra de material de laboratório e amizade.

- Ao José Monteiro e toda equipe da Fazenda Experimental do Anhembi pela manutenção da coleção de germoplasma de mandioca.

- Á todos os colegas do Curso de Pós-Graduação do Departamento de Genética, que tive a oportunidade de conviver, agradeço pelo companheirismo e amizade.

- À todos os amigos do Laboratório de Genética Ecológica pela convivência e troca de experiências profissionais, e pelo apoio nos momentos dificeis.

- Agradecimento especial ao Rainério Meireles da Silva, pelo companherismo, ajuda, incentivo e contribuição, fundamentais à execução deste trabalho de Tese.

- À minha família pela demonstração de amor, pelo carinho pela confiança e pela amizade que continua nos unindo.

- À Rossana Rebello Mendes e Lúcia Zampini Faraldo pela amizade e pela agradável companhia durante estes anos. 
- À Coordenadoria de Aperfeiçoamento de Pessoal de Ensino Superior (CAPES), pela bolsa de estudos concedida e pela atenção às reinvindicaçoes feitas durante o curso.

- À todas as demais pessoas que tornaram possível a realização deste trabalho, o meu sincero agradecimento. 


\section{SUMÁRIO}

Páginas

LISTA DE FIGURAS

LISTA DE TABELAS

RESUMO

SUMMARY .............................................................................................. xiii

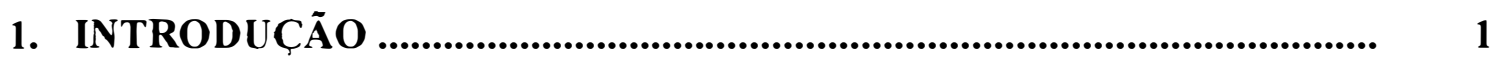

2. REVISÃO DE LITERATURA ........................................................... 6

2.1. O gênero Manihot ................................................................................ 6

2.2. Domesticação da mandioca ............................................................ 11

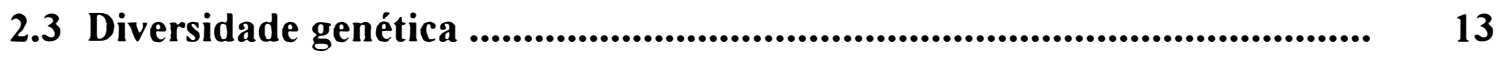

2.4. Etnovariedades .......................................................................... 16

2.5. Uso de marcadores isoenzimáticos no estudo de variabilidade de

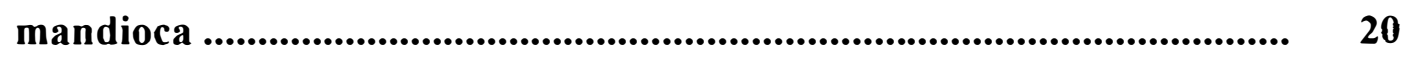

2.6. Diversidade genética e a agricultura tradicional ................................. 25

2.7. Dinâmica evolutiva em roças de mandioca $\ldots . . \ldots \ldots \ldots \ldots \ldots \ldots \ldots \ldots \ldots \ldots \ldots \ldots \ldots \ldots . . . \ldots \ldots$

3. MATERIAL E MÉTODOS............................................................. 28

3.1. MATERIAL ............................................................................................ 28

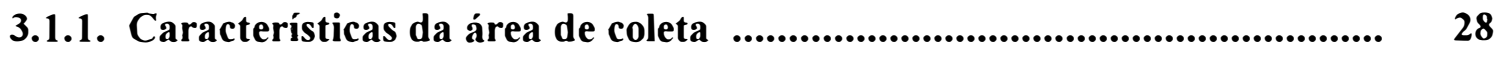

3.1.2. Etnovariedades de Manihot esculenta Crantz ....................................... 31

3.1.3. Amostragem de plantas ............................................................. 32

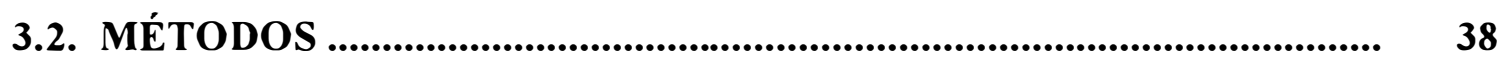

3.2.1. Caracterização genética do germoplasma utilizado ............................... 38 
3.2.2. Tecido da plantas para eletrof ore de isoenzimas ............................. 38

3.2.3. Sistemas enzimáticos utilizados ...................................................... 39

3.2.4 Procedimento de extração de enzimas .......................................... 39

3.2.5. Procedimentos de eletroforese ...................................................... 41

3.2.6. Interpretação dos zimogramas ........................................................... 48

3.2.7. Análise genético-biométrica dos dados ............................................... 49

3.2.8. Variabilidade genética em plantas ..................................................... 52

3.2.8.1. Frequência alélicas ............................................................ 52

3.2.8.2. Estimativas dos índices de diversidade genética ............................... 53

3.2.8.3. Distribuição da variabiliade genética entre e dentro de regiões geográficas ......................................................................................... 56

4. RESULTADOS E DISCUSSÃO ........................................................ 58

4.1. Procedimentos de eletroforese .......................................................... 58

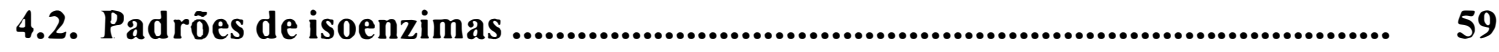

4.3. Interpretação genética de zimogramas ............................................. 65

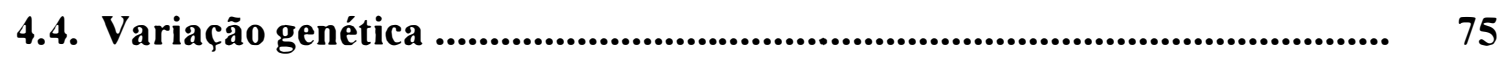

4.4.1. Variabilidade genética em nível de roça ........................................ 82

4.4.2. Variabilidade genética em nível de regiões geográficas .......................... 87

4.5. Distribuição da variabilidade genética ............................................. 91

4.6. Taxonomia "folk" .............................................................................. 95

4.7. Análise da variabilidade genética através de agrupamento $\quad$..................... 98

4.8. Análise da variabilidade genética conforme o uso das etnovariedades ... 101

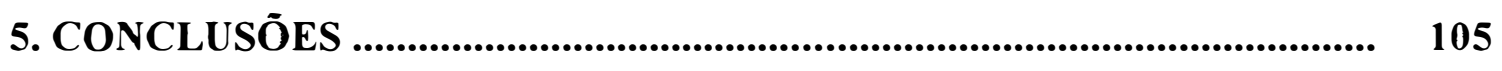

REFERÊ NCIAS BIBLIOGRÁ FICAS ....................................................... 107 


\section{LISTA DE FIGURAS}

1. Zimograma dos padrões eletroforéticos apresentando os fenótipos do sistema enzimático da aspartato aminotransferase (AAT), analisados em folhas recém expandidas de vinte e três roças de $M$. esculenta do Brasil, com seus respectivos locos, alelos e valores de referência.

2. Zimograma dos padrões eletroforéticos apresentando os fenótipos do sistema enzimático da citosol aminopeptidade (CAP), analisados em folhas recém expandidas de vinte e três roças de $M$. esculenta do Brasil, com seus respectivos locos, alelos e valores de referência.

3. Zimograma dos padrões eletroforéticos apresentando os fenótipos do sistema enzimático da malato desidrogenase $(\mathrm{MDH})$, analisados em folhas recém expandidas de vinte e três roças de $M$. esculenta do Brasil, com seus respectivos locos, alelos e valores de referência.

4. Zimograma dos padrões eletroforéticos apresentando os fenótipos do sistema enzimático da manitol desidrogenase $(\mathrm{MADH})$, analisados em folhas recém expandidas de vinte e três roças de $M$. esculenta do Brasil, com seus respectivos locos, alelos e valores de referência.

5. Zimograma dos padrões eletroforéticos apresentando os fenótipos do sistema enzimático da glutamato desidrogenase (GTDH), analisados em folhas recém expandidas de vinte e três roças de $M$. esculenta do Brasil, com seus respectivos locos, alelos e valores de referência. 
6. Zimograma dos padrões eletroforéticos apresentando os fenótipos do sistema enzimático da xiquimato desidrogenase (SKDH), analisados em folhas recém expandidas de vinte e três roças de $M$. esculenta do Brasil, com seus respectivos locos, alelos e valores de referência.

7. Zimograma dos padrões eletroforéticos apresentando os fenótipos do sistema enzimático da fosfoclucose isomerase (PGI), analisados em folhas recém expandidas de vinte e três roças de M. esculenta do Brasil, com seus respectivos locos, alelos e valores de referência.

8. Zimograma dos padrões eletroforéticos apresentando os fenótipos do sistema enzimático da enzima málica (ME), analisados em folhas recém expandidas de vinte e três roças de $M$. esculenta do Brasil, com seus respectivos locos, alelos e valores de referência.

9. Zimograma dos padrões eletroforéticos apresentando os fenótipos do sistema enzimático da glucose-6-fosfato desidrogenase $(\mathrm{G} 6 \mathrm{PDH})$, analisados em folhas recém expandidas de vinte e três roças de $M$. esculenta do Brasil, com seus respectivos locos, alelos e valores de referência.

10. Zimograma dos padrões eletroforéticos apresentando os fenótipos do sistema enzimático da fosfatase ácida ( $\mathrm{ACP}$ ), analisados em folhas recém expandidas de vinte e três roças de $M$. esculenta do Brasil, com seus respectivos locos, alelos e valores de referência.

11. Zimograma dos padrões eletroforéticos apresentando fenótipos do sistema enzimático Isocitrato desidrogenase (IDH), analisados em folhas recém expandidas de vinte e três roças de Manihor esculenta do Brasil, com seus respectivos locos, alelos e valores de referência. 
12. Zimograma dos padrões eletroforéticos apresentando fenótipos do sistema enzimático fosfoclucose isomerase (PGI) analisados me folhas recém expandidas de vinte e três rocas de Manihot esculenta do Brasil, com seus respectivos locos, alelos e valores de referência.

13. Dendrograma resultante da análise de agrupamento por padrões de distância para as 23 roças de etnovariedades de mandioca (Manihot esculenta Crantz), utilizando-se coeficientes de Distância Euclidiana Simples e algoritimo U.P.G.M.A.

14. Dendrograma resultante da análise de agrupamento por padrões de distância das regiões geográficas, utilizando-se coeficientes de Distância Euclidiana Simples e algoritimo U.P.G.M.A, em etnovariedades de mandioca (Manihot esculenta Crantz).

15. Escores provenientes da análise de coordenas principais (PCO), calculada a partir da similaridades genética de 139 amostras de etnovariedades de mandioca (Manihot esculenta Crantz), de diferentes regiões geográficas do Brasil. $\mathrm{D}=$ Material de uso desconhecido; $\mathrm{F}=$ Material usado para fabricação de farinha; e $M=$ Material de Mesa. 


\section{LISTA DE TABELAS}

1. Relação das etnovariedades de $M$. esculenta coletadas e analisadas. As etnovariedades estão listadas segundo o número de identificação da coleção ESALQ/USP, local de coleta, comunidade, roça, nome local, uso e origem do material.

2. Relação do germoplasma de mandioca coletado no Parque Indígena do Xingu: Aldeia Yawalapiti, Waurá e Autucumã.

3. Total de sistemas enzimáticos testados e sistemas que foram incluídos nas análises.

4. Cálculo do coeficiente de associação baseado em dados de presença e ausência.

5. Freqüência alélica para 15 locos isoenzimáticos nas 23 roças (populações) de etnovariedades de $M$. esculenta.

6. Variabilidade genética observada em vinte e três roças (populações) de $M$. esculenta Crantz, para os 15 locos isoenzimáticos analisados.

7. Variabilidade genética observada nas sete regiões de $M$. esculenta Crantz, para os 15 locos isoenzimáticos analisados.

8. Variabilidade genética observada nas 23 roças de etnovariedades de mandioca ( $M$. esculetna) para os 15 locos isoenzimáticos analisados.

9. Variabilidade genética observada nas 7 regiões de coleta das etnovariedades de mandioca (M. esculetna) para os 15 locos isoenzimáticos analisados. 
DISTRIBUIÇÃO DA VARIABILIDADE GENÉTICA E CARACTERIZAÇÃO ISOENZIMÁTICA DE ETNOVARIEDADES EM ROÇAS DE MANDIOCA (Manihot esculenta Crantz) DO BRASIL

\author{
Autor: Maria Inez Fernandes Faraldo \\ Orientador: Prof. Dr. Akihiko Ando
}

\title{
RESUMO
}

As etnovariedades representam uma forma de recurso genético que deve ser preservada e conservada, pois, será utilizada pelos melhoristas em programas de melhoramento no futuro, principalmente, na transferência de caracteres qualitativos de interesse econômico. As etnovariedades de mandioca (Manihot esculenta Crantz) merecem destaque dentro da associação entre conservação de recursos genéticos in situ e agricultura tradicional. A mandioca é uma das principais espécies cultivada por agricultores autóctones das regiões tropicais, especialmente, do Brasil.

O presente trabalho teve os seguintes objetivos: a) analisar a variabilidade genética em nível de roças e regiões geográficas: Região Amazônica, compreendendo o alto Amazonas (Rio Negro e Rio Branco Estados do Amazonas e Roraima); o médio Amazonas (Estado do Pará); o baixo Amazonas (Rio Solimões - Estado do Amazonas); Região de Cuiabá e Reserva Indígena do Xingu (Estado do Mato Grosso); e litoral sul do Estado de São Paulo; b) analisar a correspondência entre a classificação local da diversidade (taxonomia folk) e a classificação fenotípica realizada através 
dos padrões isoenzimáticos; e c) caracterizar as etnovariedades através de padrões isoenzimáticos.

Foram avaliadas 138 etnovariedades e 1 variedade comercial (Mantiqueira) pela técnica de eletroforese de isoenzimas, utilizando-se folhas recém expandidas, sendo estudados 11 sistemas enzimáticos (AAT, CAP, MDH, MADH, PGI, G6PDH, SKDH, PGM, ME, ACP e IDH) e avaliados 15 locos polimórficos.

A distribuição da variabilidade genética foi estimada a partir das freqüências alélicas obtidas através do coeficiente de diversidade de Nei. As estimativas dos índices de diversidade, como: porcentagem de locos polimórficos, número médio de alelos por loco e heterozigosidade média observada foram obtidas empregando-se o programa BIOSYS-1.

Os resultados obtidos revelaram níveis elevados de heterozigosidade $(\mathrm{Ho}=0,456)$. A maioria das roças apresentou excesso de homozigotos, provavelmente relacionados com o efeito de seleção a favor dos indivíduos homozigotos.

Dentre as conclusões, destacam-se as seguintes: maior concentração de variabilidade dentro das roças de uma mesma região; maior variabilidade dentro de regiões do que entre regiões; diversidade intra-específica diretamente relacionada com a estrutura sócio-cultural do local; dados de isoenzimas auxiliam as estratégias de coleta, preservação e manutenção das etnovariedades das roças de agricultura tradicional; e existe tendência de distinção entre material usado para mesa (macaxeira) e farinha (maniva ou mandioca brava). 


\title{
DISTRIBUTION OF GENETIC VARIABILITY AND ISOZYME CHARACTERIZATION OF ETHNOVARIETIES IN GARDENS OF CASSAVA (Manihot esculenta CRANTZ) FROM BRAZIL.
}

\author{
Author: Maria Inez Fernandes Faraldo \\ Advisor: Prof. Dr. Akihiko Ando
}

\section{SUMMARY}

Ethnovarieties represent a form of genetic resource which must be preserved and conserved, because they will be utilized by plant breeders in breeding programs in the future, mainly for qualitative characters transference. Cassava ethnovarieties (Manihot esculenta Crantz) deserve distinction when related to the association of in situ genetic resources conservation and traditional agriculture. Cassava is one of the main tropical species, cultivated usually by authoctone farmers of tropical regions, especially in Brazil.

The present work had the following objectives: a) analyze the genetic variability of gardens of different geographic regions: Amazonian Region, comprising the high Amazon (Rio Negro and Rio Branco - Amazon and Roraima States); the medium Amazon (Pará State), and the low Amazon (Rio Solimòes - Amazon State); Cuiabá Region and Indigenous Reserve of Xingu (Mato Grosso State); and the south coast of São Paulo State); b) analyze the correspondence between the local classification of diversity (folk 
taxonomy) and the phenotypic classification achieved through isozyme patterns; and c) characterize the ethnovarieties through isozymatic patterns.

A hundred and thirty eight ethnovarieties and one commercial variety were evaluated by the technique of isozyme electrophoresis, using recent expanded leaves. Eleven enzymatic systems (AAT, CAP, MDH, MADH, PGI, G6PDH, SKDH, PGM, ME, ACP and IDH) were studied and 15 polymorphic loci were evaluated.

The distribution of genetic variability was estimated from the allelic frequencies obtained from Nei's coefficient of diversity. The estimates of diversity indices through polymorphic loci percentage, mean number of alleles per locus and mean observed heterozygosity were obtained using the program BIOSYS-1.

The results showed high levels of heterozygosity $(\mathrm{Ho}=0.456)$. Most gardens presented excess of homozygotes, probably related to the selection effect in favor of homozygous individuals.

The main conclusions were: concentration of variability within gardens higher than among gardens within a region; higher variability within regions than among regions; intraspecific variability directly related to the social-cultural structure of the region; isozyme data support strategies of collection, preservation and maintenance of ethnovarieties in gardens of traditional agriculture; and a tendency in separating "sweet" cassava (macaxeira) from "bitter" cassava (maniva). 


\section{INTRODUÇÃO}

O desenvolvimento da agricultura criou grande diversidade genética nas espécies selecionadas para domesticação (Brush et al., 1981). O conhecimento humano gerado e acumulado ao longo dos anos sobre os aspectos da seleção, embora pré-histórico, incluiu esforços no sentido de modificar plantas e animais dos quais o homem continua dependente até os dias de hoje (Salick, 1995). Dessa forma, entende-se que a diversidade se expressa em níveis diferentes nas plantas cultivadas, podendo estar presente dentro de plantas em nível de indivíduo (heterozigosidade), entre indivíduos dentro de uma variedade heterogênea, entre variedades dentro de uma espécie ou num grande número de espécies e variedades (Soleri \& Cleveland, 1993).

Portanto, plantas cultivadas, especialmente etnovariedades, representam uma forma de recurso genético que deve ser preservado e conservado, pois será utilizado pelos melhoristas em programas de melhoramento, especialmente na transferência de caracteres qualitativos. As etnovariedades de mandioca (Manihot esculenta Crantz) merecem destaque dentro da associação entre conservação de recursos genéticos in situ e agricultura tradicional. 
O gênero Manihot é um taxon natural com origem e domesticação ainda em discussão. Manihot esculenta é uma espécie de destaque quanto a sua capacidade de crescimento e desenvolvimento em solos pobres, resistência a pragas e doenças, bem como sua adaptação em diferentes regiões edafoclimáticas. No gênero Manihot, duas espécies apresentam características de importância econômica: espécie cultivada Manihot esculenta com raízes tuberosas para fins de produção de farinha, amido e in natura, e a Manihot glaziovii que se destaca pelo seu potencial para produção de látex (borracha).

A mandioca (Manihot esculenta Crantz) é uma das principais espécies tropicais, comumente cultivada em regiões equatoriais ou tropicais, especialmente no Brasil ( com destaque dado para as regiões Norte, Nordeste e Centro-Oeste) e Oeste da Índia. Na África e principalmente nos países asiáticos, seu cultivo é um pouco mais recente. O seu limite de altitude nos trópicos não ultrapassa 2.000 metros (Hershey \& Amaya, 1989). Apresenta características favoráveis para a conservação in situ, e para estudos de diversidade genética e de evolução e adequada para o manejo sustentável.

A agricultura autóctone ou agricultura tradicional são termos muito utilizados e encontrados na literatura para designar um sistema agrícola cujas bases técnicas reportam ao Brasil pré colonial nos primórdios da descoberta da agricultura que subsiste até a atualidade, cultivada pelas populações indígenas remanescentes ou populações que assimilaram a técnica transmitida culturalmente por seus antepassados. Essas técnicas vão sendo adaptadas aos ecossistemas das regiões onde são praticadas. 
A espécie apresenta um grande valor econômico por ser a principal produtora de amido e farinha de mesa, especialmente nos países em desenvolvimento. Também é a principal espécie cultivada em manejo de agricultura autóctone mantida pelos agricultores dentro desse sistema de agricultura tradicional das regiões tropicais baixas americanas. Segundo Plucknett et al. (1987), citados por Cleveland et al. (1994), a importância da mandioca nesse sistema de agricultura está relacionada à presença de grande número de etnovariedades por roça, sendo importante fonte de diversidade genética, principalmente para características específicas (únicas) não encontradas nos materiais melhorados.

Estratégias para conservação e preservação de recursos genéticos in situ necessitam serem geradas, principalmente para evitar-se erosão genética, com ênfase especial na conservação da diversidade genética presente nas formas de agricultura tradicional. Estudos para melhor compreensão do manejo agrícola das roças, da diversidade, dos processos envolvidos com a dinâmica evolutiva das etnovariedades e suas interações com os aspectos culturais, econômicos e ecológicos das comunidades tradicionais precisam ser realizados. Com isso, certamente, haverá melhor compreensão dos processos que geram, mantém e amplificam a variabilidade dentro deste tipo de agricultura, proporcionando maior contribuição para a conservação dos recursos genéticos

O processo de modernização tecnológica relacionado com o aumento da população, alterações dos ecossistemas, introdução de novas variedades, agricultura industrial, mudanças sócio-culturais, política ambiental, têm acarretado uma diminuição das áreas de produção bem 
como alterações no manejo da agricultura autóctone tradicional, especialmente em relação a redução do tempo de pousio das áreas cultivadas, consequentemente provocando erosão genética.

Segundo Cleveland et al. (1994) um outro aspecto que também está sendo responsável pela erosão genética se encontra na eliminação de variedades primitivas relacionadas com os processos de transformação que os povos indígenas vem sofrendo como conseqüência do processo de modernização levando a perdas significativas de diversidade genética. Os agricultores e povos indígenas estão se sentindo pressionados a apresentar mudanças no manejo de suas roças, prejudicando o modo como esses povos vinham selecionando e mantendo as etnovariedades in situ como parte do sistema de agricultura local.

A conservação dos ecossistemas tropicais, e portanto a sua diversidade, caracterizada pela riqueza de espécies e presença de variabilidade genética dentro de roças, está associada à existência de alternativas que podem gerar renda para os proprietários das roças bem como sua auto sustentabilidade. Dentro deste contexto, avistou-se a possibilidade de fazer um trabalho que avaliasse a distribuição da diversidade genética dentro das roças nas diferentes regiões geográficas do Brasil.

Nesta perspectiva, e considerando a escassez de informações relativas à distribuição da variabilidade e diversidade genética de etnovariedades de mandioca dentro de roças, o presente trabalho teve por objetivos: 
a. analisar o nível de variabilidade genética observada dentro de roça, considerada como unidade básica de amostragem; entre e dentro de roças; e entre e dentro de diferentes regiões geográficas: Região Amazônica, compreendendo o alto Amazonas (Rio Negro e Rio Branco - Estados do Amazonas e Roraima), o médio Amazonas (Estado do Pará), e o baixo Amazonas (Rio Solimões - Estado do Amazonas); Região de Cuiabá e Reserva Indígena do Xingu (Estado do Mato Grosso); e litoral sul do Estado de São Paulo.

b. caracterizar as etnovariedades através de padrões isoenzimáticos.

c. analisar a correspondência entre a classificação local da diversidade (taxonomia folk) e a classificação fenotípica realizada através dos padrões isoenzimáticos;

d. caracterizar as etnovariedades através de padrões isoenzimáticos de acordo com o uso das etnovariedades. 


\section{REVISÃO DE LITERATURA}

\subsection{O Gênero Manihot}

A mandioca (Manihot esculenta Crantz), também conhecida por yuca, mandioca, aipim ou aipi, macaxeira, cassava, manioc, manioca, tapioca, , mhogo, omowgo, em suahili é uma planta arbórea cuja origem e distribuição ainda não foram bem definidas. Acredita-se ter sido domesticada pelos ameríndios porém com centro de origem com certa controvérsia (Dominguez et al., 1984; Cury, 1993; Martins, 1994).

A espécie apresenta grande potencial econômico por ser a principal produtora de farinha de mesa e amido, consumida especialmente nos países considerados em desenvolvimento como o Brasil e países africanos. Este valor econômico fez com que a mesma. fizesse parte da alimentação diária de povos, além de representar fonte adicional de renda e de subsistência para os proprietários rurais.

A mandioca pertence à classe das Dicotiledôneas, sub-classe Archichlamydeae, que se diferencia por ter perianto pouco desenvolvido; à ordem Euphorbiales; família Euphorbiaceae, Tribo Manihoteae, gênero Manihot e espécie M. esculenta (Hershey \& Amaya, 1989). 
Em 1973, Rogers \& Appan (1973) apresentaram a quinta e mais recente monografia do gênero Manihot, reconhecendo 98 espécies divididas em dezenove seções. Detalhes sobre aspectos taxonômicos e morfológicos da espécie podem ser encontrados nessa monografia bem como em Dominguez et al. (1984).

Dentro da família Euphorbiaceae, se encontram diferentes tipos de porte da planta: arbóreo, arbustivo e herbáceo. Um dos gêneros mais importantes dessa família é o Manihot. (Rogers \& Appan, 1973). O gênero Manihot apresenta cerca de 98 espécies, tendo sido a maioria estudada por Appan \& Rogers (1970) visando classificar e definir suas relações botânicas com a mandioca cultivada (Conceição, 1987).

Crantz, em 1766, na "Institutiones Rei Herbariae", foi o primeiro a publicar, o cultigen Manihot esculenta. A espécie foi introduzida na África há 400 anos atrás como fonte de alimentação (Breeching et al., 1993).

Dentre as plantas de maior interesse econômico nacional, a mandioca (Manihot esculenta Crantz) é considerada a mais brasileira de todas as plantas dada a sua ligação com o desenvolvimento histórico, social e econômico do Brasil, como cultura de subsistência, acompanhando a civilização pátria desde o descobrimento (Conceição, 1987).

A mandioca brava e o aipim ou macaxeira (mandioca mansa) pertencem à espécie Manihot esculenta Crantz. A maior ou menor quantidade de ácido cianídrico $(\mathrm{HCN})$ é a diferença fundamental entre as duas formas. A substância tóxica é encontrada em todas as partes da planta. 
A característica mais utilizada na classificação popular de etnovariedades de mandioca é a diferença entre o sabor amargo ou doce que muitas vezes está correlacionado com a presença de ácido cianídrico em diferentes concentrações, que confere toxicidade à cultura. As etnovariedades consideradas de sabor amargo não são muito apreciadas para o consumo in natura mas são consumidas na forma de farinha, polvilho e tapioca.

Colombo (1997) e Mühlen (1999) conseguiram separar as variedades de mandioca de acordo com a prática de uso pelos agricultores: em de mesa e/ou farinha, através de marcadores de DNA como RAPD, microssatélites, RFLP e AFLP. Estas evidências observadas estão relacionadas com o processo de domesticação da mandioca.

Conceição (1987), também relatou que cultivares de mandioca podem ser classificados de acordo com a finalidade de uso em: industriais, para mesa, para forragem e mistas.

A espécie $M$. esculenta pode apresentar diferentes formatos de raízes: cônica, cilíndrica, fusiforme, estrangulada, tortuosa ou globulosa. As folhas são simples, inseridas no caule com disposição alterna-espiralada, lobadas e longamente pecioladas. Os lobos apresentam variação quanto à cor, formato, número e tamanho. As flores se dispõem em inflorescências cimosas. Flores masculinas são em menor número e se localizam nas extremidades de ramificação da inflorescência; e as flores femininas, em número mais reduzido e de tamanho maior, na base. $O$ fruto é uma cápsula com duas ou três sementes e que se abre (estoura) por seis valvas quando completamente maduro. As sementes são carunculadas, providas de testa e 
tegumento, micrópila, hilo, rafe e chalaza. O embrião é central com folhas cotiledonares grandes; o endosperma é abundante e oleaginoso (Conceição, 1987).

Pouco se conhece a respeito da citogenética do gênero Manihot. O primeiro pesquisador a realizar estudo citológico da mandioca (Manihot esculenta) foi Graner em 1935 com seu clássico trabalho intitulado "Contribuição para o estudo citológico da mandioca", no qual observou duzentas metáfases num total de 37 variedades de mandioca, sendo que 36 apresentaram cromossomos com 1 a $2 \mathrm{~mm}$ de comprimento por aproximadamente $0,3 \mathrm{~mm}$ de largura. Autores como Cruz (1968), Umanah \& Hartmann (1973) encontraram 2n=36 cromossomos nas espécies estudadas inclusive na mandioca cultivada. Perry (1943) e Umanah \& Hartmann (1973) sugerem que o número básico de cromossomos do gênero Manihot é $\mathrm{x}=9$.

Poucos trabalhos têm sido realizados no sentido de se obter híbridos artificiais através do cruzamento entre o material cultivado e seus parentes selvagens (Storey \& Nichols, 1938; Jennings, 1959; Carvalho, 1995).

Experimentos realizados com espécies diferentes de Manihot têm mostrado fortes barreiras de incompatibilidade, devido a nem sempre os cruzamentos entre espécies do gênero Manihot resultarem na formação de híbridos férteis, o que sugere que o sistema de incompatibilidade segue o sistema de barreira reprodutiva proposto por Harlan \& de Wet (1971). 
Trabalhos vêm sendo executados com sucesso em relação ao fluxo gênico (Silva Jardim, 1984) e dinâmica dos alelos nas populações de etnovariedades de mandioca (Silva, 1999).

Rogers iniciou estudos taxonômicos do gênero Manihot em 1952. O objetivo principal foi estudar a evolução da espécie cultivada, porém ficou claro que estudos taxonômicos de uma espécie domesticada, para uma maior segurança, devem ser precedidos de análise sistemática detalhada dentro do complexo de planta cultivada, selvagens e derivadas. As amostras do cultigen $M$. esculenta encontradas nos herbários não foram suficientes para descrever a variabilidade e fazer a classificação. Em 1953, estudos de campo foram iniciados no Oeste da Índia e na Costa Rica, envolvendo métodos de amostragem, registros e preparação de herbário documentado com o material observado (Rogers \& Appan, 1973).

Em cada região brasileira existem cultivares tradicionais que vêm sendo investigados pelos pesquisadores, para que se possa, futuramente, conservá-los ou substitui-los por outros que reunam maior soma possível de características agronômicas de interesse econômico (Conceição, 1987).

Segundo Martins (1994), uma grande vantagem apresentada pela mandioca está relacionada com a conservação de suas raízes no solo por períodos flexíveis, de acordo com o consumo e necessidades do agricultor local, possibilitando a colheita durante todo o ano. Além disso, apresenta características agronômicas interessantes, modo diversificado de sistema de reprodução (sexual e/ou assexual), variabilidade genética, possibilidade de cruzamento entre as espécies selvagens e o material 
cultivado originando híbridos interespecíficos (hibridação introgressiva), grande difusão, e ser a principal espécie cultivada pelo sistema de agricultura autóctone do Brasil e de várias regiões tropicais da América.

O conjunto de características apresentado pela cultura da mandioca faz desse material uma espécie ideal para estudos de evolução, mais diretamente envolvidos com manutenção, geração e amplificação da variabilidade genética da mandioca, consequentemente, acarretando implicações no sistema de conservação de recursos genéticos in situ.

\subsection{A domesticação da mandioca}

A pequena quantidade de informações e evidências arqueológicas, genéticas, taxonômicas, citogenéticas e evolutivas, faz da história da domesticação da mandioca uma questão ainda em aberto e bastante polêmica.

A maior parte das evidências arqueológicas do cultivo da mandioca são indiretas e se baseiam na presença de cerâmicas e pedaços de pedras, os quais parecem ser derivados de "raladores", artefatos utilizados no processamento da mandioca, entre muitos grupos primitivos de índios das terras baixas da América do Sul (Renvoize, 1973).

A indicação mais antiga acerca da utilização da mandioca como alimento está baseada em evidências arqueológicas encontradas na parte norte da América do Sul. Estudos feitos no norte da Venezuela e Colômbia por Rouse \& Cruxent (1963) e por Reichel-Dolmatoff $(1957,1965)$ citados por Hershey \& Amaya (1989), dão evidências da presença de artefatos para 
o processamento da mandioca, numa idade correspondente entre $3.000 \mathrm{e}$ 7.000 anos. Porém, estas evidências não servem para provar o cultivo da mandioca nessa época, uma vez que poderiam ser amostras de uma espécie selvagem.

Para muitos autores, como Jennings (1979), Manihot esculenta não é encontrada na forma selvagem; aparentemente parece ser uma espécie cujo cultivo surgiu por processos de seleção natural, hibridação e pelo próprio cuidado do homem. O gênero ocorre naturalmente no hemisfério ocidental, entre o sudeste dos Estados Unidos $\left(33^{\circ} \mathrm{N}\right)$ e Argentina $\left(33^{\mathrm{O}} \mathrm{S}\right)$. Mostra grande diversidade no nordeste do Brasil, estendendo-se até próximo ao Paraguai, e no oeste e sul do México. Dessa forma, a história de sua domesticação ainda continua sendo um assunto em discussão, devido à existência de poucos registros arqueológicos e etnobotânicos disponíveis até o momento.

Contrariando algumas opiniões de que a mandioca é um cultigen, Allem (1987) considera M. esculenta como uma espécie domesticada que ocorreu no estado selvagem, e que por interferência do homem (queimadas de áreas, etc.) e pela interferência da própria natureza (seleção natural), através do tempo, acabou se tornando uma espécie cultivada. Novas informações sugerem que a mandioca existe naturalmente em uma considerável área do neotrópico. O autor também acredita que a origem botânica da mandioca se perdeu no passado geológico (Allem, 1987). 
A espécie Manihot baccata encontrada no oeste da Amazônia foi descrita por Allem (1999). Trata-se da mais nova e recente espécie dentro do gênero Manihot.

Carvalho (1999) mostrou através de técnicas moleculares que a mandioca cultivada é um produto $100 \%$ de origem brasileira. Segundo este autor, o ancestral da espécie foi encontrado na Amazônia comprovando a hipótese de Allem nos anos 70.

Segundo Hershey (1992), no Brasil a distribuição de espécies de Manihot coincide com áreas de expansão rápida da agricultura, especialmente em áreas de cerrado do Brasil Central.

O germoplasma de mandioca cultivada será importante fonte de diversidade genética para programas de melhoramento. Pesquisas têm mostrado que a partir de acessos mantidos nos Bancos de Germoplasma (BAGs) é possível transferir genes resistentes ao Vírus Mosaico Africano da Manihot glaziovii. Fica evidente a importância de dispensar esforços no sentido de direcionar e manter coleções tanto in situ quanto ex situ, para que o material possa ser utilizado em estudos de melhoramento e evolução. Hershey (1992) e Martins (1994) também destacam a importância das espécies selvagens do gênero Manihot para contribuir na compreensão dos processos evolutivos da dinâmica da mandioca, bem como seu impacto em programas de melhoramento genético e estudos de domesticação de plantas.

\subsection{Diversidade Genética}

Diversidade genética é um conceito tem sido empregado em dois sentidos distintos. O primeiro se refere à riqueza de espécies presente 
dentro de um ecossistema (Wolda, 1981; Ludwing \& Reynolds, 1988). O segundo se refere ao nível de heterozigosidade de uma população obtido a partir das freqüências alélicas (Nei, 1973). Este valor eqüivale à quantidade de heterozigotos esperada, valor esse que demonstra o nível de variação genética em uma população de uma determinada espécie.

Além da heterozigosidade, outros índices de diversidade tem sido utilizados para avaliar a variação genética de populações, como porcentagem de locos polimórficos e número de alelos por loco, tendo por finalidade caracterizar e comparar os níveis de variações genéticas na populações (Alfenas et al., 1991).

Dentre as metodologias empregadas para medir a diversidade genética, destacam-se os marcadores de locos alozímicos (Brown, 1978). Estes marcadores apresentam como características a neutralidade e a codominância. Hamrick (1985) discute o valor adaptativo dos alelos destes locos, apesar das evidências acima citadas.

Um outro aspecto importante dentro desse item "Diversidade Genética" é a conservação e o melhoramento de recursos genéticos vegetais com base em comunidades de agricultores (Frankel et al., 1998).

Os agricultores têm manejado recursos genéticos desde que começaram a cultivar plantas, bem como apresentam papel de destaque no processo de domesticação de plantas cultivadas. Porém, ao longo das últimas décadas, esse manejo tem escapado progressivamente ao seu controle. Hoje em dia, parece existir um crescente reconhecimento do papel das comunidades locais e especialmente dos pequenos agricultores, no 
desenvolvimento e conservação dos recursos genéticos vegetais (Salick, 1995).

Para muitos agricultores a diversidade no sentido social, econômico ou genético, significa segurança. A diversidade genética permite ao agricultor ter uma maior segurança contra pragas, doenças e condições climáticas inesperadas, além de garantir maior nível de variabilidade genética através de processos de recombinação, mutação que ocorrem naturalmente no ambiente (Gaifami \& Cordeiro, 1994).

Uma característica bastante marcante nas práticas de cultivo pelos agricultores tradicionais é a utilização de duas ou mais variedades de uma mesma espécie dentro de uma única roça, ou seja, ao invés de usar variedades "modernas" (melhoradas), os agricultores conseguem produções maiores através da utilização de espécies diferentes e de variedades tradicionais diferentes (no mínimo duas por roça), sendo cada uma adaptada especificamente ao micro-ambiente (roça) no qual são cultivadas. Dentro desse modo de manejar o material genético observa-se que uma das principais vantagens em se manter as variedades locais, em lugar das variedades "modernas" e "uniformes", que só alcançam o seu potencial se o ambiente também for uniforme, necessitando de solos de alta qualidade (uso de fertilizantes e irrigação), é que variedades tradicionais conseguem sobreviver mesmo em condições adversas ao seu meio ambiente adaptandose rapidamente ao novo habitat, não necessitando de fertilizantes agrícolas que normalmente estão fora do alcance do pequeno agricultor (Brush, 1995). 
Algumas variedades de mandioca presentes na roça podem ser adequadas ao consumo imediato e outras ao armazenamento a longo prazo. Essa riqueza genética e cultural torna-se um importante reservatório de diversidade para a agricultura mundial (Martins, 1994).

Nos sistemas agrícolas, as comunidades desenvolveram estratégias próprias, baseadas em milhares de anos de experiência e no profundo conhecimento de suas necessidades. Grande parte dessas estratégias preservam a diversidade genética. Além disso, as variedades tradicionais empregadas pelos agricultores tendem a ter maior diversidade do que as "modernas".

Peroni \& Martins (1995) relataram que a diversidade dentro dos sistemas agrícolas tradicionais é semelhante a encontrada no centro de origem da espécie.

\subsection{Etnovariedades}

O termo "landrace" foi utilizado pela primeira vez no ano de 1890, porém a primeira definição foi publicada há 20 anos atrás. Maiores detalhes podem ser encontrados na revisão feita por Zeven (1998), que define o termo "autochthonous landrace" (variedade primitiva) como uma variedade com elevada capacidade de tolerância ao estresse biótico e abiótico, resultando em alta estabilidade de produção e nível intermediário de produção sob baixas condições do sistema agrícola.

Existe, atualmente, uma preocupação muito grande com o fenômeno da erosão genética em áreas de agricultura tradicional, as quais 
estão sendo atingidas pela modernização de técnicas agrícolas, adotando novas variedades no lugar das tradicionais.

Autores como Quiros (1990), Altieri (1992) e Brush (1992), estão preocupados com as alterações que estão ocorrendo na agricultura tradicional, provocadas pelos processos de modernização tecnológica, mudanças sociais e pela introdução de novas variedades, destacando a importância da conservação das etnovariedades para manter a diversidade genética local.

Etnovariedades ou variedades primitivas ou raças locais, são definidas por Brown (1978) citado por Cleveland et al. (1994), como populações que possuem diferenças geográficas e ecológicas, bem como composição genética distinta tanto a nível populacional como entre populações, originadas a partir de processo de seleção local, executada pelos agricultores.

Os agricultores, na maioria das vezes, mantém as etnovariedades mesmo na presença de novas variedades. O motivo que leva o produtor a essa prática cultural ainda não foi bem discutido nem pesquisado, porém, alguns pontos podem ser considerados, como: armazenamento do material para alimento e nutrição; por razões históricas, culturais e sociais do local; cerimônias religiosas, etc.(Cleveland et al., 1994).

Cury (1993), com o objetivo de identificar e caracterizar áreas de agricultura autóctone do Litoral Sul do Estado de São Paulo (Vale do Ribeira) através de estudos de caracterização morfológica, conseguiu estabelecer um modelo para a dinâmica evolutiva de M. esculenta Crantz, 
que sugere ser a diversidade real, maior do que a reconhecida pelos agricultores, o que pode implicar em mudanças na metodologia de coleta de germoplasma. Esse modelo, no sistema de agricultura autóctone, mantém e amplifica a variabilidade intra-específica através da ação de mutação, recombinação e fluxo gênico.

Faraldo (1994) trabalhou com sete roças (populações clonais) de agricultura autóctone da região do Estado de São Paulo, com o objetivo de caracterizar e quantificar a variabilidade isoenzimática observada nas etnovariedades de mandioca ( $M$. esculenta), através de eletroforese de enzimas em gel de penetrose 30. Concluiu que a diversidade intraespecífica está diretamente relacionada com a estrutura sócio-cultural do local, e que dados de isoezimas servem para auxiliar os melhoristas nas estratégias de melhoramento genético nas roças de agricultura autóctone, no sentido de detectar a distribuição da variabilidade genética presente nas populações.

Sambatti (1998), também nessa linha de pesquisa amostrou plantas de mandioca de cinco roças da região de Ubatuba-SP (litoral paulista), as quais pertenciam a quatro agricultores diferentes, sendo dois considerados praticantes do manejo tradicional e dois com manejo alterado. Foram avaliados caracteres isoenzimáticos obtidos através de eletroforese de enzimas em gel de amido para os sistemas enzimáticos leucilaminopeptidase (LAP), xiquimato desidrogenase ( $\mathrm{SKDH})$, fosfoglucose isomerase (PGI) e malato desidrogenase $(\mathrm{MDH})$, com o objetivo de comparar a diversidade genética de roças de mandioca com manejos diferentes bem como entender o efeito do manejo na diversidade genética. 
Além de caracterizar o material com isoenzimas, também foram avaliados 22 caracteres morfológicos e realizada análise dos componentes de solo para saber quais características estariam contribuindo para separar as roças de manejo tradicional das de manejo alterado. O autor concluiu que ocorre erosão genética na espécie $M$. esculenta no município de Ubatuba (SP) como conseqüência da redução no período de pousio causada pelas restrições às atividades agrícolas impostas pela legislação ambiental.

Peroni (1998), estudou 10 roças de mandioca (M. esculenta Crantz) manejadas por agricultores tradicionais autóctones do sul do litoral paulista e do Vale do Ribeira, na região de Iguape, com o objetivo de determinar a variabilidade intra-específica de mandioca, ao nível das etnovariedades através de isoenzimas e de morfologia, bem como avaliar e comparar a variabilidade reconhecida e nomeada pelo agricultor e interpretar os padrões de variabilidade sob o modelo de dinâmica evolutiva da mandioca (Cury, 1993). Concluiu que os agricultores subestimam a variabilidade presente intra-roça, dando o mesmo nome a genótipos diferentes. Além disso, foi possível concluir que cada etnovariedade de mandioca é constituída por genótipos distintos, com grande semelhança na morfologia, compondo uma população heterogênea. Do ponto de vista da interpretação dos resultados baseado no modelo de dinâmica evolutiva da mandioca, foi possível inferir que esses genótipos foram gerados via hibridação intra-específica.

Cury (1998), avaliou a distribuição da diversidade genética e as correlações de caracteres morfológicos, agronômicos e químicos de 56 etnovariedades de mandioca (Manihot esculenta Crantz) provenientes de 
áreas de agricultura tradicional autóctone das regiões do Rio Negro (Amazonas), Rio Solimões (Amazonas) e litoral sul do Estado de São Paulo e concluiu que a região com maior diversidade genética foi a do Rio Negro, seguida da região do Rio Solimões e por último a região do litoral sul do Estado de São Paulo. Observou também que o padrão de dispersão multivariado das etnovariedades foi contínuo, com apenas uma etnovariedade (DG-71) distanciando-se das demais, sugerindo que na população de origem da DG-71 esteja ocorrendo hibridação introgressiva. Não foi encontrada variação geográfica.

\subsection{Uso de marcadores isoenzimáticos no estudo de variabilidade de mandioca.}

A técnica de eletroforese de enzimas vem sendo utilizada desde a década de 1950 (Smithies, 1955) com muita eficiência para estimar e avaliar o grau de variabilidade genética em populações naturais, estudos de fluxo gênico, hibridação, relação filogenética, entre outros estudos. Além disso, a freqüência de tais estudos que utilizam essa técnica vem aumentando e sendo cada vez mais aprimorada e aceita, mesmo frente às modernas técnicas (Hills et al., 1995). O uso dessa técnica representou um salto muito grande para estudos de populações naturais de plantas, pois esses estudos eram realizados com base nas variações genéticas de caracteres qualitativos e quantitativos.

Dentro deste contexto, centros nacionais e internacionais de pesquisa em agricultura têm mostrado grande interesse na caracterização e 
manutenção de germoplasma, bem como grande preocupação em aumentar, a cada ano, a coleção com a introdução de novos acessos. Dentre esses centros merece destaque o Centro Internacional de Agricultura Tropical CIAT, na Colômbia, e o Centro de Recursos Genéticos e Biotecnologia CENARGEN, e Instituto Agronômico de Campinas - IAC, ambos no Brasil. A técnica de eletroforese de enzimas tem se mostrado altamente eficiente e confiável para a caracterização de germoplasma presente nos bancos.

Dentro do Brasil, a maior preocupação na preservação do material se localiza na Bacia Amazônica, onde coletas esporádicas têm sido feitas (Gulick et al., 1983; Morishima \& Martins, 1994).

A técnica da eletroforese de enzimas em gel de amido têm sido amplamente utilizada como marcador genético-bioquímico, sendo aplicada em estudos de taxonomia numérica, genética de plantas, animais e microrganismos, análises filogenéticas, e principalmente, na identificação e caracterização de materiais que fazem parte de coleções dos bancos de germoplasma espalhados por todo o mundo (Alfenas et al., 1991).

Ramirez et al. (1987) determinaram o padrão isoenzimático de diferentes variedades de mandioca, obtido a partir de 16 sistemas enzimáticos, através da técnica de eletroforese de enzimas em gel de poliacrilamida. O padrão enzimático observado variou conforme o tecido utilizado (folha, raiz, pecíolo, gemas foliares), apresentando maior ou menor número de bandas. Demonstraram que, dos 16 sistemas enzimáticos analisados, quatro sistemas ACP (fosfatase ácida), EST (esterase), GOT (glutamato oxalacético) e PGI (fosfoglucose isomerase) já seriam 
suficientes para caracterizar o material em estudo, servindo como marcadores isoenzimáticos.

Hussain et al. (1987), utilizando a técnica de eletroforese de enzimas em gel de poliacrilamida à $12 \%$, determinaram o padrão isoenzimático específico apresentado pela enzima esterase (EST) na identificação de treze cultivares diferentes de mandioca, com o objetivo de tornar a metodologia empregada uma rotina na identificação de cultivares de mandioca baseado nos padrões isoenzimáticos das esterases.

Grattapaglia et al. (1987), interessados em relacionar dados de genética bioquímica com dados de taxonomia, utilizaram a técnica de eletroforese de proteína solúvel em gel de poliacrilamida com SDS na avaliação de sementes em 19 espécies do gênero Manihot. Concluíram que os perfis eletroforéticos apresentados pelas bandas no gel apresentaram-se correlacionados com a ocorrência de variabilidade morfológica, hábito de crescimento e distribuição geográfica do gênero.

Lefèvre \& Charrier (1993b) descreveram a diversidade isoenzimática de 365 cultivares de $M$. esculenta e mais 109 acessos de parentes selvagens (M. glaziovii e híbridos espontâneos) da África. O estudo se baseou em 17 locos polimórficos. M. esculenta e M. glaziovii apresentaram baixos níveis de polimorfismo, sendo a heterozigosidade estimada em 0.225 e 0.252 , respectivamente. Para espécies selvagens, a diversidade se mostrou representada por um único loco; e a análise multilocos revelaram padrão geográfico. A organização da diversidade na mandioca cultivada parece não ser clara, porém, um estudo baseado em 
alelos raros e comuns, pode levar à identificação de diferentes grupos de clones com muitos genótipos intermediários.

A técnica da eletroforese em gel de amido foi utilizada para a avaliação do nível de polimorfismo isoenzimático em duas espécies do gênero Manihot. Extratos bruto foram obtidos de folhas não expandidas e de pólen. Para o estudo foram analisados 365 cultivares e 109 acessos selvagens, principalmente vindos da África. A herança destas enzimas foi examinada utilizando 13 progênies intra e interespecífica. Dezessete locos polimórficos foram observados para os dez sistemas enzimáticos, com um total de 59 alelos. Todos os padrões revelados pelas enzimas, mostraram heterogeneidade dissômica e três grupos de ligação foram identificados. (Lefèvre \& Charrier, 1993a.).

Borsoi Filho (1995), em seu trabalho, estudou a variabilidade isoenzimática, em tecido de raiz e folha, de seis cultivares de mandioca $(M$. esculenta Crantz), em condições normais e em regime de estresse hídrico e ataque por ácaros (Monony chellus tanajoa). $\mathrm{O}$ autor concluiu que: 1.) os seis sistemas enzimáticos analisados ACP (fosfatase ácida), GOT (glutamato oxilacético), GDH (glutamato desidrogenase), LAP (leucil aminopeptidase), $\mathrm{MDH}$ (malato desidrogenase) e PER (peroxidase) são estáveis em condições normais; 2.) os sistemas $\mathrm{ACP}, \mathrm{MDH}$ e $\mathrm{PER}$, não apresentam padrões alterados, quando as plantas são submetidas às condições de estresses; 3.) as cultivares Moça-Branca e Sete-Égua são as que apresentaram maior divergência genética, pelo índice de "Jaccard"; 4.) o método de Tocher permitiu a formação de dois grupos, sendo um deles formado apenas por uma cultivar. 
Faraldo (1994) caracterizou 30 etnovariedades de mandioca (Manihot esculenta Crantz) pertencentes a 7 diferentes roças localizadas no litoral sul do Estado de São Paulo, através da técnica de eletroforese de enzimas em gel de penetrose 30 à $13 \%$. Um total de 12 locos foram identificados, sendo 9 locos polimórficos, pertencentes à cinco sistemas enzimáticos: malato desidrogenase (MDH - E.C. 1.1.1.37), leucil aminopeptidase (LAP - E.C. 3.4.11.1), xiquimato desidrogenase (SKDH E.C.1.1.1.25), alfa-esterase (Alfa-EST - E.C. 3.1.1.1) e aspartato aminotransferase (AAT - E.C. 2.6.1.1). O polimorfismo isoenzimático observado mostrou que populações do litoral apresentaram maior variabilidade que populações do vale. Parâmetros de heterozigosidade média estimados demonstraram índice de variação genética maior nas roças estudadas $(\mathrm{H}=0,242)$ do que a média de dados observados na literatura $(\mathrm{H}$ $=0,225)$. Análises de dados pelo índice de similaridade genética através dos métodos "Simple Matching" e "Jaccard" e agrupamento U.P.G.M.A., resultaram em quatro grupos fenéticos distintos.

Autores como Peroni (1998) e Sambatti (1998) também utilizaram a técnica de eletroforese de enzimas em gel de amido de milho (penetrose 30 - à 13\%), para caracterizar etnovariedades de mandioca ( $M$. esculenta) em roças de agricultura tradicional autóctone, e para analisar nível de polimorfismo isoenzimático e distribuição da variabilidade genética bem como da diversidade. Silva (1999) utilizou marcadores isoenzimáticos para avaliar a dinâmica de alelos em etnovariedades de mandioca. 


\subsection{Diversidade genética e agricultura tradicional}

A maneira mais prática, aplicada e geral de se utilizar a diversidade genética é beneficiar a sociedade humana através dos programas e processos de melhoramento genético das culturas (Hershey, 1992).

Sabe-se que dentro da utilização de "landraces" de mandioca somente $2 \%$ do total geral tem sido utilizada em programas de melhoramento, número esse aparentemente baixo, porém é bastante alto quando se compara com outras culturas também de interesse econômico. Mesmo assim, o número de "landraces" que contribuem para clones elite fica ao redor de $1 \%$.

A manutenção da diversidade genética na natureza é processada através de espécies de fecundação cruzada obrigatória indicando grande importância de se gerar diferentes tipos de genótipos para ocupar os diferentes "habitats". Entretanto, ao lado desse mecanismo diversificado e inovador existe um altamente conservador: a reprodução vegetativa, por meio de brotamento de manivas (mandioca), brotamento de raizes (araçá, bacuri, etc.), bulbos, possibilitando o máximo de preservação da espécie de plantas (Clement, 1980).

Dentro desse mecanismo conservador de variabilidade genética, pode-se destacar a mandioca que é bastante cultivada entre as diferentes tribos indigenas que ocupam a Região Amazônica, onde são cultivadas grande número de variedades por tribo (20 variedades/tribo, em 
média), chegando nos Desâna e Tukâna a 40 variedades. Dessa forma, a diversidade genética é mantida e conservada na natureza (Clement, 1980).

Já em 1980, o mesmo autor sugere um trabalho integrado dos pesquisadores de Agricultura, Medicina, Ecologia e de Botânica assim como de outros órgãos de pesquisa, na tentativa de aproveitar ao máximo o conhecimento, as práticas e as sementes dos índios amazônicos. O mesmo pode ser sugerido e aproveitado para os pequenos agricultores que manipulam suas roças obedecendo o manejo tradicional autóctone.

\subsection{Dinâmica evolutiva em roças de mandioca.}

Cury $(1993$; 1998) e Martins (1994) propuseram um modelo que denominaram de "modelo da dinâmica evolutiva da mandioca", levando em consideração o fato dessa cultura apresentar sistema reprodutivo sexual capaz de gerar recombinantes, além de ser reproduzida vegetativamente (através de clones - manivas) pelos agricultores dentro das roças. Dessa forma, clones diferentes são gerados, mantidos e incorporados, pelos agricultores nas roças. Assim, os agricultores mantém o conjunto original de etnovariedades através de reprodução clonal do material genético obtido através da germinação espontânea de sementes (processo sexual).

Segundo Sambatti (1998), uma das vantagens de se estudar evolução em plantas cultivadas está relacionada com o depoimento dos agricultores que é muito valioso e que deve ser considerado em conjunto com os dados obtidos na experimentação, pois estes acumulam na memória 
fatos que ocorreram no passado ligados a uma determinada população, como está sendo realizado no Laboratório de Genética Ecológica da ESALQ/USP. 


\section{MATERIAL E MÉTODOS}

\subsection{MATERIAL}

\subsubsection{Características das áreas de coleta}

O presente trabalho foi conduzido a partir de amostras coletadas em roças de agricultura tradicional autóctone, localizadas em diferentes regiões geográficas do Brasil. O material avaliado não representa a totalidade da variabilidade genética da região, e sim pontos aleatórios de coletas dentro das regiões consideradas. A primeira área pertencente à região do Rio Negro no Estado do Amazonas-AM; a segunda localiza-se no Estado de Roraima às margens do Rio Branco; a terceira área de coleta está localizada em comunidades da região de Cuiabá, Estado do Mato Grosso; a quarta área localiza-se na bacia do Rio Solimões no Estado do Amazonas; a quinta área pertence ao litoral sul do Estado de São Paulo; a sexta área de coleta localiza-se nas cidades de Monte Alegre, Óbidos, Santarém e Belém localizadas no Estado do Pará; e a sétima e última região pertence ao Estado do Mato Grosso na área de reserva indígena do Xingu.

Em todas as áreas de coleta foram estabelecidos critérios de amostragem, visando detectar a existência de variabilidade genética entre 
os indivíduos de uma mesma roça e entre roças distintas. Dessa forma, cada área amostrada ficou definida como uma população não natural, uma vez que existe a influência do homem no processo de seleção inconsciente, de maneira que o agricultor "seleciona" o que vai plantar em sua roça, prática essa mantida há muito anos.

Deve ficar claro que esta amostragem não é representativa de uma região como por exemplo da região Amazônica, da região do litoral sul do Estado de São Paulo ou da região do Mato Grosso, e sim de localidades escolhidas ao acaso.

Cada região (área) amostrada ficou definida como um conjunto de populações clonais, de forma que o termo "população" foi empregado para definir o conjunto de etnovariedades presentes na roça para aquele local de coleta em questão.

De cada roça foi coletado todo material genético (manivas) identificado pelo agricultor como diferente, caracterizando uma amostragem fixa e direcionada. Observa-se que o número de etnovariedades presentes nas roças variou muito de um local para outro, como é o caso da roça localizada na cidade de Óbidos (PA) que apresentou 21 genótipos, e outras com 2 ou 3 genótipos distintos.

As etnovariedades coletadas nas diferentes regiões geográficas do Brasil foram trazidas para o Departamento de Genética da Escola Superior de Agricultura "Luiz de Queiroz" da Universidade de São Paulo (ESALQ-USP) em Piracicaba-SP. A coleção formada pelo material trazido da Região Norte do Brasil (Amazonas e Pará) encontra-se resumidamente descrita em Martins (1994). A coleção composta pelas etnovariedades da 
Região Centro-Oeste (Mato Grosso) encontra-se descrita em Amorozo (1996) e Freitas (1997 - comunicação pessoal) ${ }^{1}$. Com relação ao material genético coletado no litoral sul do Estado de São Paulo, maiores detalhes podem ser encontrados em Cury (1993), Faraldo (1994) e Peroni (1998). A variedade comercial Mantiqueira (DG-137) lançada comercialmente pelo Instituto Agronômico de Campina (IAC) foi utilizada como referência.

Na região do Rio Negro, as amostras de manivas de mandioca foram obtidas de roças localizadas em diferentes comunidades. As roças da região apresentam extensão média de $0,5 \mathrm{ha} /$ roça, cujo período de cultivo ocorre de 2 a 3 anos, retornando-se à mesma área após 5 a 10 anos. Normalmente, o material doce (macaxeira) é plantado isolado da mandioca brava (mandioca) dentro das roças. Uma outra curiosidade diz respeito à prática de policulturas, onde são encontrados materiais diversificados como batata doce, ariá, cubiu, etc. No caso da mandioca, o padrão de distribuição espacial dos indivíduos dentro da roça obedece o agrupado. Observou-se também bancos de sementes após o retorno à roça antiga.

O Rio Negro é considerado um importante canal de drenagem da bacia Amazônica com ligação com outros rios importantes da Amazônia. Em geral, apresenta nível de água mais alto nos meses de maio a junho, podendo chegar a 30 metros de altura, e mais baixo no mês de novembro, ao redor de 10 metros. Dados obtidos no porto de Manaus mostraram que há variação no nível da água de ano para ano, nível esse que aumenta gradualmente e decresce rapidamente (Morishima \& Martins, 1994).

O Rio Negro, como o nome indica, apresenta água escura devido a alta acidez, possuindo $\mathrm{pH}$ entre 4,6 e 5,5. Enquanto que o Rio

${ }^{1}$ Fábio de Oliveira Freitas, comunicação pessoal, 1997. Laboratório de Genética Ecológica - Departamento de Genética ESALQ/USP. 
Branco, que possui águas claras, apresenta $\mathrm{pH} 5,1$ a 7,0. A bacia do Rio Solimões é caracterizado por solo fértil, com alta produtividade primária e alta diversidade de peixes e pássaros. Já a bacia do Rio Negro apresenta solo pobre por falta de elementos minerais (Noda \& Yuyama, 1994).

\subsubsection{Etnovariedades de Manihot esculenta Crantz}

As etnovariedades a serem analisadas foram coletadas em 1992 nas regiões do médio Amazonas, Rio Negro e Rio Branco; em 1993 na região do Rio Solimões; no ano de 1994 em Mato Grosso, região de Cuiabá, e em 1997, na região do Parque Indígena do Xingu.

Em cada localidade foram escolhidas, ao acaso, algumas roças, sendo que em cada roça foram coletadas as etnovariedades identificadas pelo agricultor e no caso da região do Xingu, além dos agricultores, também material identificado pelos índios. Cada etnovariedade foi representada por um clone.

A partir desse material, as manivas foram colhidas e plantadas em vasos em casa de vegetação do Departamento de Genética, ESALQ/USP, em Piracicaba-SP, e transplantadas para a Estação Experimental de Anhembi, que se localiza a mais ou menos $60 \mathrm{~km}$ da cidade de Piracicaba, local este também mantido pela ESALQ/USP.

O material genético utilizado foi composto de 138 etnovariedades e uma variedade comercial (DG-137) proveniente do IAC (Instituto Agronômico de Campinas-SP), sendo 25 etnovariedades do Rio Negro, 9 do Rio Branco, 15 do Rio Solimões, 18 etnovariedades do Médio 
Amazonas, 21 etnovariedades do Estado do Pará, 22 da região do Mato Grosso, 17 da região do Xingu, e 11 de São Paulo (Tabelas 1 e 2 ).

O termo etnovariedade adotado no presente trabalho segue a definição sugerida por Brown (1978) citada por Cleveland et al. (1994), ou seja, populações que apresentam diferenças genéticas, ecológicas e geográficas, e que são originadas por processo de seleção local praticada pelos próprios agricultores.

\subsection{Amostragem de plantas.}

A estimativa da diversidade genética requer metodologia de amostragem rigorosa e acurada, onde parâmetros de estrutura populacional são ou podem ser estimados. Dessa forma, se a amostragem não for criteriosa, conclusões erradas poderão ser obtidas.

No caso do material objeto deste estudo, a amostragem seguiu o critério de Hershey (1992) e Martins (1994). Segundo esses autores, o sistema de propagação influencia fortemente a estratégia de amostragem. A mandioca apresenta propagação vegetativa preferencialmente, portanto, a amostra pode ser de uma planta individual, que será geneticamente idêntica a todas as outras plantas do mesmo clone ou variedade. Já quando se considera espécies selvagens de mandioca, há necessidade de coletar todas as plantas de uma mesma variedade, pois apresenta sistema de cruzamento e propagação por sementes, podendo cada planta ser geneticamente distinta. Um número suficiente de plantas é necessário além de uma amostragem acurada da frequência de alelos na população. 
Tabela 1. Relação das etnovariedades de $M$. esculenta coletadas e analisadas. As etnovariedades estão listadas segundo o número de identificação da coleção ESALQ/USP, local de coleta, comunidade, roça, nome local, uso e origem do material.

\begin{tabular}{|c|c|c|c|c|}
\hline $\begin{array}{c}\text { Número } \\
\text { Identificação }\end{array}$ & $\begin{array}{c}\text { Roça/ } \\
\text { Localidade }\end{array}$ & $\begin{array}{l}\text { Nome } \\
\text { Local }\end{array}$ & Uso & $\begin{array}{c}\text { Distribuição } \\
\text { Geográfica }\end{array}$ \\
\hline$\overline{38}$ & \multirow[t]{2}{*}{$\begin{array}{l}\text { Comunidade } \\
\text { Piloto/Barcelos }\end{array}$} & Maniva Inajá & Farinha & $\begin{array}{c}\text { RIO NEGRO } \\
\text { AM }\end{array}$ \\
\hline 39 & & Macaxeira Branca & Mesa & \\
\hline 40 & \multirow[t]{4}{*}{$\begin{array}{l}\text { Comunidade } \\
\text { Marará/Barcelos }\end{array}$} & Branquinha & Farinha & \\
\hline 41 & & Sem Nome & Farinha & \\
\hline 42 & & Mandioca S. João & Farinha & \\
\hline 43 & & Pretinha & Farinha & \\
\hline 44 & \multirow[t]{3}{*}{\begin{tabular}{|l} 
Com.D.PedroII/ \\
Barcelos/Anati
\end{tabular}} & Mand. do Antônio & Farinha & \\
\hline 45 & & Macaxeira & Mesa & \\
\hline 46 & & Orelha de Burro & Farinha & \\
\hline 47 & \multirow[t]{9}{*}{$\begin{array}{l}\text { Roça-1/ } \\
\text { Carvoeiro }\end{array}$} & Mamaroca & Farinha & \\
\hline 48 & & Tartaruga & Farinha & \\
\hline 49 & & Amarela II & Farinha & \\
\hline 50 & & Olho Roxo & Farinha & \\
\hline 51 & & Pretinha & Farinha & \\
\hline 52 & & Seis Meses & Farinha & \\
\hline 53 & & Sem Identificação-3 & Farinha & \\
\hline 54 & & Antinha & Farinha & \\
\hline 55 & & Anará & Farinha & \\
\hline 56 & \multirow[t]{7}{*}{$\begin{array}{l}\text { Roça-1/ } \\
\text { Carvoeiro }\end{array}$} & Araoari & Farinha & \\
\hline 57 & & Paca Branca & Farinha & \\
\hline 58 & & Amarela I & Farinha & \\
\hline 59 & & Samuauma & Farinha & \\
\hline 61 & & Macaxeira & Farinha & \\
\hline 62 & & Sem Identificação-2 & Farinha & \\
\hline 63 & & Açai & Farinha & \\
\hline 64 & \multirow[t]{4}{*}{ Roça-1/Marará } & & & $\begin{array}{c}\text { RIO BRANCO } \\
\text { RR }\end{array}$ \\
\hline 65 & & Anará & Farinha & \\
\hline 66 & & Açaizinho & Farinha & \\
\hline 67 & & Roxinha & Farinha & \\
\hline
\end{tabular}




\begin{tabular}{|c|c|c|c|c|}
\hline $\begin{array}{c}\text { Número } \\
\text { Identificação }\end{array}$ & $\begin{array}{c}\text { Roça/ } \\
\text { Localidade }\end{array}$ & $\begin{array}{l}\text { Nome } \\
\text { Local }\end{array}$ & Uso & $\begin{array}{c}\text { Distribuição } \\
\text { Geográfica }\end{array}$ \\
\hline 68 & \multirow{2}{*}{$\begin{array}{l}\text { Roça-1/ } \\
\text { Castanho }\end{array}$} & Macaxeira Pão & Farinha & \\
\hline 69 & & Camarão & Farinha & \\
\hline 70 & \multirow[t]{3}{*}{$\begin{array}{l}\text { Roça-1/ } \\
\text { Panacarica }\end{array}$} & Tala Encarnada & Farinha & \\
\hline 72 & & Leiteira & Farinha & \\
\hline 73 & & Socó & Farinha & \\
\hline 75 & \multirow{8}{*}{$\begin{array}{l}\text { Barreirinho } \\
\text { Sto.Ant.do } \\
\text { Lèverger }\end{array}$} & $\begin{array}{ll}\begin{array}{l}\text { Folha } \\
\text { branca }\end{array} & \text { fina/raiz } \\
\end{array}$ & ------- & $\begin{array}{c}\text { MATO } \\
\text { GROSSO-MT } \\
\end{array}$ \\
\hline 76 & & Abóbora (roxinha) & ---------- & \\
\hline 77 & & Aparecida & ---------- & \\
\hline 78 & & Sopa & -------- & \\
\hline 79 & & Aquino & 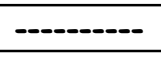 & \\
\hline 82 & & Amarguenta & 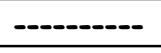 & \\
\hline 84 & & Gaiadeira Preta & --------- & \\
\hline 85 & & Amarelinha & --------- & \\
\hline 86 & \multirow{3}{*}{$\begin{array}{l}\text { Barreirinho } \\
\text { Varginha }\end{array}$} & Acurizal & --------- & \\
\hline 88 & & Gaiadeira/Vermelha & 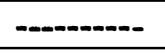 & \\
\hline 89 & & $\begin{array}{l}\text { Pegou com Antônio } \\
\text { Pedro }\end{array}$ & -------- & \\
\hline 90 & \multirow{4}{*}{$\begin{array}{l}\text { Estraira } \\
\text { Barreirinho }\end{array}$} & Gaiadeira Vermelha & --------- & \\
\hline 91 & & Ponte de Ferro & 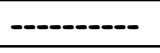 & \\
\hline 94 & & Mata Rato & -ב-_-.--- & \\
\hline 95 & & Mata Rato & |--------- & \\
\hline 97 & \multirow{7}{*}{$\begin{array}{l}\text { Estraira } \\
\text { Varginha } \\
\text { Barreirinho } \\
\text { St.Ant.de } \\
\text { Lèverger }\end{array}$} & Mata Rato (grande) & ---------- & \\
\hline 98 & & Mata Rato (pequena) & |--------- & \\
\hline 99 & & Impim Preto & --------- & \\
\hline 100 & & Vermelha & --------- & \\
\hline 101 & & Impim Vermelho & --------- & \\
\hline 104 & & Rama Dura & --------- & \\
\hline 105 & & Pato dos Gaúchos & -------- & \\
\hline 111 & \multirow[t]{3}{*}{$\begin{array}{l}\text { Roça-1/1 } \\
\text { Comunidade S. } \\
\text { Sebastião/Varini }\end{array}$} & Geoató & Farinha & $\begin{array}{l}\text { RIO } \\
\text { SOLIMÕES }\end{array}$ \\
\hline 112 & & Pretinha & Farinha & \\
\hline 113 & & Antinha & Farinha & \\
\hline 115 & $\begin{array}{l}\text { Roça-1/ } \\
\text { Comunidade S. } \\
\text { João/Guarabira }\end{array}$ & Maguari & Farinha & \\
\hline
\end{tabular}




\begin{tabular}{|c|c|c|c|c|}
\hline $\begin{array}{c}\text { Número } \\
\text { Identificação }\end{array}$ & $\begin{array}{c}\text { Roça/ } \\
\text { Localidade }\end{array}$ & $\begin{array}{l}\text { Nome } \\
\text { Local }\end{array}$ & Uso & $\begin{array}{c}\text { Distribuição } \\
\text { Geográfica }\end{array}$ \\
\hline 116 & & Ourinho & Farinha & \\
\hline 117 & & Caneorá & Farinha & \\
\hline 118 & & Macaxeira & Farinha & \\
\hline 119 & & Macaxeira & Farinha & \\
\hline 120 & & Antinha & Farinha & \\
\hline 121 & & Turuna & Farinha & \\
\hline 122 & & Marreca de Semente & Farinha & \\
\hline 123 & & $\begin{array}{l}\text { AntinhaXMarreca } \\
\text { (hibrido) }\end{array}$ & Farinha & \\
\hline 124 & & Macaxeira & Farinha & \\
\hline 125 & $\begin{array}{l}\text { Roça-1/Lago } \\
\text { Ananã }\end{array}$ & Sem identificação & Farinha & \\
\hline 138 & Lago Maniá & Antinha & Farinha & \\
\hline 139 & \multirow{18}{*}{$\begin{array}{l}\text { Quintal/Monte } \\
\text { Alegre } \\
\text { Roça-1/Monte } \\
\text { Alegre } \\
\text { Roça-2/Monte } \\
\text { Alegre } \\
\text { Quintal/Monte } \\
\text { Alegre } \\
\text { Roça-1/Monte } \\
\text { Alegre/Airi }\end{array}$} & Macaxeira Sebo & --.---- & $\begin{array}{c}\text { MÉDIO } \\
\text { AMAZONAS PA }\end{array}$ \\
\hline 143 & & Macaxeira Manteiga & ---------- & \\
\hline 145 & & Tucumã & ---------- & \\
\hline 147 & & Virana & 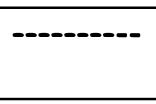 & \\
\hline 149 & & Acari & ---------- & \\
\hline 150 & & Macaxeira Preta & --_------ & \\
\hline 151 & & Inambu & 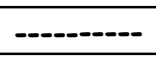 & \\
\hline 152 & & Mocinha & ---------- & \\
\hline 153 & & Inambu Paru & --------- & \\
\hline 154 & & Mocinha & 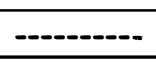 & \\
\hline 155 & & Branca & 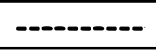 & \\
\hline 156 & & Amarela Galhenta & 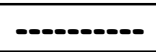 & \\
\hline 157 & & Amarelana Direta & -.---.----- & \\
\hline 158 & & Macaxeira & --------- & \\
\hline 160 & & Najá & 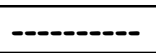 & \\
\hline 162 & & Piraiba & -ב-------- & \\
\hline 163 & & Bem-Te-Vi & ---------- & \\
\hline 164 & & $\begin{array}{l}\text { Macaxeira (Camarão } \\
\text { Crú Italiana) }\end{array}$ & --------- & \\
\hline$\overline{165}$ & \multirow[t]{4}{*}{$\begin{array}{l}\text { Roça-l/Obidos/ } \\
\text { Campina }\end{array}$} & Coari & --:---- & BELÉM PA \\
\hline 166 & & MilagrosaGrande & -.-.-.-.-. & \\
\hline 170 & & Macaxeira Branca & 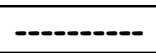 & \\
\hline 175 & & Cadete & --.------ & \\
\hline
\end{tabular}




\begin{tabular}{|c|c|c|c|c|}
\hline $\begin{array}{c}\text { Número } \\
\text { Identificação }\end{array}$ & $\begin{array}{c}\text { Roça/ } \\
\text { Localidade }\end{array}$ & $\begin{array}{l}\text { Nome } \\
\text { Local }\end{array}$ & Uso & $\begin{array}{c}\text { Distribuição } \\
\text { Geográfica }\end{array}$ \\
\hline 176 & & Marciana & -ב-.-- & \\
\hline \multicolumn{5}{|l|}{177} \\
\hline \multicolumn{5}{|c|}{ Pororoca } \\
\hline \multicolumn{5}{|c|}{ 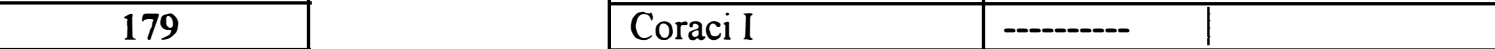 } \\
\hline \multicolumn{5}{|c|}{--------- } \\
\hline \multicolumn{5}{|l|}{181} \\
\hline \multicolumn{5}{|c|}{ Achada Preta } \\
\hline 184 & & Mamão & 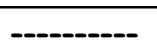 & \\
\hline \multicolumn{5}{|l|}{185} \\
\hline \multicolumn{4}{|c|}{ Nunguba } & \\
\hline \multicolumn{5}{|c|}{ Seis Meses } \\
\hline \multicolumn{5}{|l|}{189} \\
\hline \multicolumn{5}{|c|}{ Pororoca } \\
\hline \multicolumn{5}{|c|}{ Semente-1 } \\
\hline \multicolumn{5}{|c|}{ Semente-2 } \\
\hline \multicolumn{5}{|c|}{ Semente-5 } \\
\hline \multirow{2}{*}{\multicolumn{5}{|c|}{ Semente-6 }} \\
\hline & & & & \\
\hline \multirow{2}{*}{$\begin{array}{l}126 \\
127\end{array}$} & \multirow[t]{7}{*}{ Cananéia } & Aipim Roxo & Farinha & $\overline{\text { SĀO PAULO }}$ \\
\hline & & $\begin{array}{ll}\text { Aipim } & \text { Roxo } \\
\text { Semente }\end{array}$ & Farinha & \\
\hline \multirow{5}{*}{$\begin{array}{l}128 \\
129 \\
130 \\
131 \\
132\end{array}$} & & Manteiga & Mesa & \\
\hline & & Aipim Mata Fome & Mesa & \\
\hline & & Vassourinha & Mesa & \\
\hline & & Manteiguinha & Mesa & \\
\hline & & Aipim Roxo & Mesa & \\
\hline \multirow{4}{*}{$\begin{array}{l}133 \\
134 \\
135 \\
136\end{array}$} & \multirow[t]{4}{*}{ Ilha Comprida } & Manteiga & Mesa & \\
\hline & & Aipim Roxo & Mesa & \\
\hline & & Vermelha & Mesa & \\
\hline & & Embrapa & ------- & \\
\hline 137 & IAC & Mantiqueira & Mesa & \\
\hline
\end{tabular}

O material genético avaliado, no presente trabalho, foi coletado a partir de estacas colhidas de uma ou no máximo duas plantas que o agricultor identificava como sendo diferente (Martins, 1994; Amorozo, 1996; Freitas, 1997). 
Tabela 2: Relação do germoplasma de mandioca coletado no Parque Indígena do Xingu: Aldeia Yawalapiti, Waurá e Autucumã.

\begin{tabular}{|c|c|c|c|c|}
\hline $\begin{array}{l}\text { Número de } \\
\text { Identificação }\end{array}$ & $\begin{array}{l}\text { Dono da } \\
\text { Roça }\end{array}$ & Nome local & Uso & Origem \\
\hline DG-403 & $\begin{array}{l}\text { Cunhado } \\
\text { Aritana } \\
\end{array}$ & do Céu & \begin{tabular}{|l} 
mandioca \\
doce-mingal
\end{tabular} & Aldeia Waurá \\
\hline $\begin{array}{l}\text { DG-404 } \\
\text { DG-406 }\end{array}$ & $\begin{array}{l}\text { Cunhado } \\
\text { Aritana } \\
\text { Caçuele } \\
\text { (Waurá) }\end{array}$ & $\begin{array}{l}\text { Flecha } \\
\text { Kayabí }\end{array}$ & $\begin{array}{l}\text { polvilho } \\
\text { polvilho e } \\
\text { mingal }\end{array}$ & $\begin{array}{l}\text { deles mesmo } \\
\text { Tribo } \\
\text { Inhâmbiquara- } \\
\text { RO }\end{array}$ \\
\hline DG-407 & Barriga & Aviti/Amarela & & Tribo Kayabí \\
\hline DG-408 & Barriga & Kayabí II (nova) & polvilho & Tribo Kayabí \\
\hline DG-409 & Airé & Branca & polvilho & deles mesmo \\
\hline DG-411 & Aritana & Ularuru ** & polvilho & deles mesmo \\
\hline $\begin{array}{l}\text { DG-412 } \\
\text { DG-414 }\end{array}$ & $\begin{array}{l}\text { Aritana } \\
\text { Outro cunhado }\end{array}$ & $\begin{array}{l}\text { Anta (Tisiâma) } \\
\text { Cuiuí (Pássaro } \\
\text { Jacu) }\end{array}$ & & \\
\hline DG-416 & Uuí & da Piranha & mingal & deles \\
\hline DG-418 & Maricáua & do Céu (antiga) & polvilho doce & semente \\
\hline DG-419 & Opuá & $\begin{array}{c}\text { do Céu (mais } \\
\text { nova) }\end{array}$ & doce-mingal & semente \\
\hline DG-420 & $\begin{array}{l}\text { Talaquai } \\
\text { Talaquai }\end{array}$ & $\begin{array}{c}\text { dos } \\
\text { Inhãnbiquaras } \\
\text { Tsicaraté } \\
\end{array}$ & $\begin{array}{c}\text { doce-mingal } \\
\text { polvilho } \\
\end{array}$ & $\begin{array}{c}\text { Tribo } \\
\text { Inhãnbiquara- } \\
\text { RO } \\
\text { deles }\end{array}$ \\
\hline DG-422 & Autucumã & $\begin{array}{l}\text { do céu-Enuta } \\
\text { Kutsa }\end{array}$ & desconhecido & $\begin{array}{c}\text { sobrinha achou } \\
\text { por semente }\end{array}$ \\
\hline DG-423 & Autucumã & $\begin{array}{l}\text { da gaivota - } \\
\text { Kankanha }\end{array}$ & desconhecido & $\begin{array}{c}\text { antiga, deles } \\
\text { mesmo }\end{array}$ \\
\hline DG-424 & Autucumã & Pú - do peixe & desconhecido & $\begin{array}{c}\text { antiga, deles } \\
\text { mesmo }\end{array}$ \\
\hline
\end{tabular}

* é mais fraca, apodrece se deixar mais de um ano na terra ** "mandioca verdadeira" - é a mandioca que mais se planta para polvilho. 


\subsection{Métodos}

\subsubsection{Caracterização genética do germoplasma utilizado.}

A caracterização genética foi realizada empregando-se marcadores bioquimicos (isoenzimas), revelados a partir de eletroforese em gel de amido de milho (penetrose 30 ), seguindo as recomendações de Alfenas et al. (1991) e Ferraz et al. (1994).

\subsubsection{Tecidos das plantas para eletroforese de isoenzimas}

As análises de eletroforese de isoenzimas foram realizadas utilizando-se tecidos foliares recém expandidos, a partir de plantas adultas mantidas no campo (aproximadamente com 12 meses de idade). A sistemática de coleta, inclusive transporte e armazenagem das folhas recém expandidas foi determinada a partir de avaliações preliminares, procurandose não alterar padrões de atividades enzimáticas do tecido empregado.

$\mathrm{O}$ método que apresentou menores riscos foi transportar o material coletado em caixinhas de plástico individuais para cada amostra, as quais foram armazenadas dentro de caixa térmica com gelo, até o laboratório, onde eram utilizadas imediatamente. $\mathrm{O}$ material não utilizado no dia era mantido em geladeira $\left(5^{\circ}\right.$ a $\left.8^{\circ} \mathrm{C}\right)$ até sua utilização no dia seguinte. 


\subsubsection{Sistemas enzimáticos utilizados}

A Tabela 3 mostra os sistemas enzimáticos testados e utilizados nas análises.

\subsubsection{Procedimento de extração de enzimas}

Para a extração das enzimas foram utilizadas amostras de $0,20 \mathrm{~g}$, aproximadamente, de folhas recém expandidas, maceradas com 5 gotas de solução tampão de extração (Scandalios, 1969) constituída de:

- Tampão Tris $0,1 \mathrm{M} \mathrm{pH} \mathrm{7,5}$

$200 \mathrm{ml}$

- Sacarose 0,2 M

$6,892 \mathrm{~g}$

- P.V.P. (PolivinilPirrolidona)

$1,20 \mathrm{~g}$

- E.D.T.A. $1 \mathrm{mM}$

$0,6724 \mathrm{~g}$

- Albumina Bovina

$0,2 \mathrm{~g}$

O tecido foliar foi macerado, com auxílio de um bastão de vidro, sobre placas de acrílico resfriadas e mantidas sobre barras de gelo durante o processo de extração, em ambiente com temperatura ao redor de $20^{\circ} \mathrm{C}$, para evitar a desnaturação das enzimas. A maceração era realizada até a completa homogeneização do tecido.

Os extratos de cada uma das amostras eram absorvidos em pedaços de papel filtro (Whatman $\mathrm{n}^{\circ} 3$ ), com dimensões de $4 \mathrm{~mm} \times 1,7 \mathrm{~mm}$. Estes papéis eram colocados verticalmente lado a lado no gel (de 20 a 22 
Tabela 3. Total de sistemas enzimáticos testados e sistemas que foram incluídos nas análises.

\begin{tabular}{|c|c|c|}
\hline Enzima & Código * & Sigla \\
\hline Alfa-esterase & E.C. 3.1 .1 .1 & Alfa-EST \\
\hline Catalase & E.C.1.11.1.6 & $\mathrm{CAT}$ \\
\hline Citosol aminopeptidase & E.C. 3.4 .11 .1 & $\mathrm{CAP} * *$ \\
\hline Fosfatase alcalina & E.C. 3.1 .3 .1 & ALP \\
\hline Fosfatase ácida & E.C. 3.1 .3 .2 & $\mathrm{ACP} * *$ \\
\hline Fosfoglucomutase & E.C. 2.7 .5 .1 & PGM** \\
\hline 6-Fosfogluconato desidrogenase & E.C. 1.1 .1 .44 & 6PGDH \\
\hline Fosfoglucose isomerase & E.C. 5.3 .1 .9 & PGI** \\
\hline Enzima málica & E.C. 1.1 .1 .40 & $\mathrm{ME}^{* *}$ \\
\hline Glucose-6-fosfato desidrogenase & E.C. 1.1 .1 .49 & G6PDH** \\
\hline Glutamato desidrogenase & E.C. 1.4 .1 .3 & GTDH \\
\hline Aspartato aminotransferase & E.C. 2.6.1.1 & $\operatorname{AAT} * *$ \\
\hline Isocitrato desidrogenase & E.C. 1.1 .1 .42 & $\mathrm{IDH}^{* *}$ \\
\hline Malato desidrogenase & E.C. 1.1 .1 .37 & $\mathrm{MDH}^{* *}$ \\
\hline Manitol desidrogenase & E.C. 1.1 .1 .67 & $\mathrm{MADH}^{* *}$ \\
\hline Peroxidase & E.C. 1.11 .1 .7 & PRX \\
\hline Xiquimato desidrogenase & E.C. 1.1 .1 .25 & $\mathrm{SKDH}^{* *}$ \\
\hline
\end{tabular}


amostras por gel). Nas duas extremidades do gel foram adicionados papéis embebidos em solução de azul de bromofenol (na proporção de 0,04 g/100ml de água) com a finalidade de marcar a linha de frente durante a migração.

\subsubsection{Procedimentos de eletroforese}

A técnica de eletroforese de proteínas baseou-se na migração das isoenzimas em meio suporte de gel de amido de milho (penetrose 30) a $13 \%$, em camadas horizontais, sendo utilizados três sistemas de tampão gel/eletrodo, discriminados logo abaixo, descritos por Claytom \& Tretiak (1972) sistema CM, Soltis et al. (1983) sistema TC e Wendel \& Weeden (1990) para o sistema AB. Abaixo, pode-se encontrar a composição destes tampões.

\section{Tampão A (pH 8,3)}

Hidróxido de lítio $2,098 \mathrm{~g}$

Ácido bórico $11,748 \mathrm{~g}$ $\mathrm{H}_{2} \mathrm{O}$ q.s.p. $1000 \mathrm{ml}$

Tampão B (pH 8,3)

Tris $6,178 \mathrm{~g}$

Ácido cítrico $1,680 \mathrm{~g}$

$\mathrm{H}_{2} \mathrm{O}$ q.s.p $1000 \mathrm{ml}$ 


\section{Tampão citrato morfolina (CM) $\mathrm{pH} \quad 6,1$}

(eletrodo)

Ácido cítrico $(0,040 \mathrm{M})$

$8,410 \mathrm{~g}$

$\mathrm{N}-(3$-Aminopropyl) morfolina $(0,068 \mathrm{M})$

$10 \mathrm{ml} / 1$

Para o gel, diluir 1:20 tampão do eletrodo

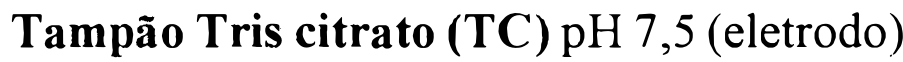

Tris $(0,223 \mathrm{M})$

$27,0 \mathrm{~g} / \mathrm{l}$

Ácido cítrico $(0,086 \mathrm{M})$

$18,07 \mathrm{~g} / 1$

Para o gel, diluir 3,5\% tampão do eletrodo

Durante a migração, os géis eram mantidos dentro de balcão frigorifico, com temperatura de aproximadamente $4^{\circ} \mathrm{C}$, com corrente constante de $20 \mathrm{~mA}$ durante os primeiros 30 minutos e $40 \mathrm{~mA}$ após esse período, sendo conservada até o final da corrida. A voltagem inicial (pré corrida) para o sistema $\mathrm{AB}$ era de 150 volts; para o sistema $\mathrm{TC}$ era de 70 volts e para o sistema $\mathrm{CM}$ de 100 volts. Passado o período de meia hora, as voltagens eram alteradas para 280 volts, 110 volts e 150 volts, respectivamente. Os papéis de filtro com as amostras foram retirados 30 minutos após o início da migração. O tempo de corrida era de aproximadamente 8 horas, quando o marcador de bromofenol atingia $8 \mathrm{~cm}$ de migração.

Terminada a corrida, os géis foram fatiados com fio de nylon de $0,20 \mathrm{~mm}$ e resistência para $2,1 \mathrm{~kg}$, em 5 fatias de $1,5 \mathrm{~mm}$ de espessura, sendo a primeira fatia desprezada para a coloração. 
Foram utilizados 12 sistemas enzimáticos nas diferentes camadas do gel, empregando-se as receitas descritas por Alfenas et al. (1991), os quais são listados e descritos a seguir:-

- Aspartato Aminotransferase (AAT) - E.C. 2.6.1.1 (Alfenas et al., 1991)

- Ácido L-aspártico

$0,150 \mathrm{~g}$

- Ácido alfa-cetoglutárico

$0,100 \mathrm{~g}$

- Tris $\mathrm{HCl} 0,2 \mathrm{M}, \mathrm{pH} \mathrm{8,0} \mathrm{(q.s.p.)}$

$100 \mathrm{ml}$

Ajustar o $\mathrm{pH}$ para 8,0, com $\mathrm{NaOH}$, e adicionar:

- Piridoxal - 5 - fosfato

$0,005 \mathrm{~g}$

- Fast Blue BB salt

$0,100 \mathrm{~g}$

Procedimento:- O gel foi mergulhado nessa solução e incubado no escuro à $37^{\circ} \mathrm{C}$, até o aparecimento das bandas; tempo de revelação: 50 minutos.

- Citosol Aminopeptidase (CAP) - E.C. 3.4.11.1 (Alfenas et al., 1991)

- L-Leucil-Beta-naftilamida-HCl

$0,015 \mathrm{~g}$

- Fast Black K salt

$0,030 \mathrm{~g}$

- Tampão Tris-maleato, pH 6,0

$100 \mathrm{ml}$ 
Procedimento: diluíram-se os dois reagentes no tampão e os géis foram mergulhados na solução e incubados no escuro; tempo de revelação: 60 minutos; temperatura: $37^{\circ} \mathrm{C}$.

- Malato Desidrogenase (MDH) - E.C. 1.1.1.37 (Brewer \& Sing, 1970)

- DL-Ácido málico 0,5 M, pH 8,0

$04 \mathrm{ml}$

- MTT

$1,2 \mathrm{ml}(10 \mathrm{mg} / \mathrm{ml})$

$-\mathrm{NAD}^{+}$

$3,3 \mathrm{ml}(10 \mathrm{mg} / \mathrm{ml})$

- PMS

$1,5 \mathrm{ml}(1 \mathrm{mg} / \mathrm{ml})$

- Tampão Tris-Ácido málico pH 7,0)

$50 \mathrm{ml}$

Procedimento: Todos os reagentes de coloração foram diluídos no tampão e a este foi acrescentado a solução do substrato; os géis foram mergulhados na solução e incubados no escuro; tempo de revelação: 45 minutos; temperatura: $37^{\circ} \mathrm{C}$.

- Xiquimato Desidrogenase (SKDH) - E.C. 1.1.1.25 (Alfenas et al., 1991)

- Ácido Xiquímico

$0,100 \mathrm{~g}$

- MTT

$1,0 \mathrm{ml}(10 \mathrm{mg} / \mathrm{ml})$

$-\mathrm{NADP}^{+}$

$1,0 \mathrm{ml}(10 \mathrm{mg} / \mathrm{ml})$

- PMS

$1,0 \mathrm{ml}(1 \mathrm{mg} / \mathrm{ml})$

- Tampão Tris $\mathrm{HCl}$ 0,1 M, pH 8,5

$50 \mathrm{ml}$ 
Procedimento: Misturam-se todos os reagentes e posteriormente os géis foram mergulhados nesta solução e incubados no escuro; tempo de revelação: 40 minutos; temperatura: $37^{\circ} \mathrm{C}$.

- Fosfoglucose isomerase (PGI) - E.C. 5.3.1.9 (Alfenas et al., 1991)

- Frutose-6-fosfato

$0,0375 \mathrm{~g}$

$-\mathrm{NADP}^{+}$

$1,0 \mathrm{ml}(10 \mathrm{mg} / \mathrm{ml})$

- MTT ou NBT

$1,0 \mathrm{ml}(10 \mathrm{mg} / \mathrm{ml})$

- PMS

$1,0 \mathrm{ml}(1 \mathrm{mg} / \mathrm{ml})$

$-\mathrm{MgCl}_{2}(1 \%)$

$1,0 \mathrm{ml}(10 \mathrm{mg} / \mathrm{ml})$

- Glucose-6-fosfato desidrogenase (G6PDH)

10 unidades

- Tampão Tris- $\mathrm{HCl}(0,1 \mathrm{M}$ - pH 8,0)

$50 \mathrm{ml}$

- Fosfoglucomutase (PGM) - E.C. 2.7.5.1 (Alfenas et al., 1991)

- Glucose-1-fosfato, $\mathrm{Na}_{2}$

- EDTA

- NADP ${ }^{+}$

- MTT

- PMS

$-\mathrm{MgCl}_{2}(1 \%)$

- Glucose-6-fosfato desidrogenase (G6PDH)

- Tampão Tris- $\mathrm{HCl}(0,1 \mathrm{M}$ - pH 8,5)
$0,125 \mathrm{~g}$

$0,025 \mathrm{~g}$

$1,0 \mathrm{ml}(10 \mathrm{mg} / \mathrm{ml})$

$1,0 \mathrm{ml}(10 \mathrm{mg} / \mathrm{ml})$

$1,0 \mathrm{ml}(1 \mathrm{mg} / \mathrm{ml})$

$1,0 \mathrm{ml}(10 \mathrm{mg} / \mathrm{ml})$

20 unidades

$50 \mathrm{ml}$ 
- Manitol desid rogenase (MADH) - E.C. 1.1.1.67 (Alfenas et al., 1991)

- Manitol

- NADP ${ }^{+}$

- MTT ou NBT

- PMS

- Tampão Tris- $\mathrm{HCl}(0,1 \mathrm{M}$ - pH 8,5)
$0,05 \mathrm{~g}$

$1,0 \mathrm{ml}(10 \mathrm{mg} / \mathrm{ml})$

$1,0 \mathrm{ml}(10 \mathrm{mg} / \mathrm{ml})$

$1,0 \mathrm{ml}(1 \mathrm{mg} / \mathrm{ml})$

$50 \mathrm{ml}$

- Enzima málica (ME) - E.C. 1.1.1.40 (Alfenas et al., 1991)

- DL-Ácido málico (2,0M - pH 8,0)

$5,0 \mathrm{ml}$

- NADP ${ }^{+}$

$1,0 \mathrm{ml}(10 \mathrm{mg} / \mathrm{ml})$

- MTT ou NBT

$1,0 \mathrm{ml}(10 \mathrm{mg} / \mathrm{ml})$

- PMS

$1,0 \mathrm{ml}(1 \mathrm{mg} / \mathrm{ml})$

$-\mathrm{MgCl}_{2}(1 \%)$

$1,0 \mathrm{ml}(10 \mathrm{mg} / \mathrm{ml})$

- Tampão Tris- $\mathrm{HCl}(0,1 \mathrm{M}$ - pH 8,0)

$50 \mathrm{ml}$

- Glutamato desidrogenase (GTDH) - E.C. 1.4.1.3 (Alfenas et al., 1991)

- Ácido L-glutâmico

$1,0 \mathrm{~g}$

- MTT ou NBT

$1,0 \mathrm{ml}(10 \mathrm{mg} / \mathrm{ml})$

- NAD

$1,5 \mathrm{ml}(10 \mathrm{mg} / \mathrm{ml})$

- PMS

$0,5 \mathrm{ml}(1 \mathrm{mg} / \mathrm{ml})$

- Tampão Tris- $\mathrm{HCl}(0,1 \mathrm{M}$ - pH 8,0)

$50 \mathrm{ml}$ 
- Isocitrato desidrogenase (IDH) - E.C. 1.1.1.42 (Alfenas et al., 1991)

- DL-Ácido isocítrico

$-\mathrm{NADP}^{+}$

- MTT ou NBT

- PMS

$-\mathrm{MgCl}_{2}(1 \%)$

- Tampão Tris- $\mathrm{HCl}(0,1 \mathrm{M}$ - pH 8,0)
$0,10 \mathrm{~g}$ $1,0 \mathrm{ml}(10 \mathrm{mg} / \mathrm{ml})$ $1,0 \mathrm{ml}(10 \mathrm{mg} / \mathrm{ml})$ $1,0 \mathrm{ml}(1 \mathrm{mg} / \mathrm{ml})$ $1,0 \mathrm{ml}(10 \mathrm{mg} / \mathrm{ml})$ $50 \mathrm{ml}$

- Glucose-6-fosfato desidrogenase (G6PDH)-E.C.1.1.1.49 (Alfenas et al., 1991)

- Gluc ose-6-f osfato

$0,10 \mathrm{~g}$

$-\mathrm{NADP}^{+}$

$1,0 \mathrm{ml}(10 \mathrm{mg} / \mathrm{ml})$

- MTT ou NBT

$1,0 \mathrm{ml}(10 \mathrm{mg} / \mathrm{ml})$

- PMS

$1,0 \mathrm{ml}(10 \mathrm{mg} / \mathrm{ml})$

$-\mathrm{MgCl}_{2}(1 \%)$

$1,0 \mathrm{ml}(10 \mathrm{mg} / \mathrm{ml})$

- Tampão Tris- $\mathrm{HCl}(0,2 \mathrm{M}$ - pH 8,0)

$50 \mathrm{ml}$

- Fosfatase ácida (ACP) - E.C. 3.1.3.2 (Silva, 1999).

- Alfa nafitil ácido fosfato de sódio

$0,05 \mathrm{~g}$

- Fast itr red

$0,1 \mathrm{~g}$

$-\mathrm{MgCl}_{2}(1 \%)$

$1,0 \mathrm{ml}(10 \mathrm{mg} / \mathrm{ml})$

- Tampão Acetato de sódio $(0,6 \mathrm{M}$ - pH 4,8)

$50 \mathrm{ml}$ 
Procedimento: Todos os reagentes de coloração foram diluídos na solução tampão e a esta foi acrescentada a solução do substrato; os géis foram mergulhados na solução e incubados no escuro; tempo de revelação: de 30 minutos a 60 minutos; temperatura: $37^{\circ} \mathrm{C}$.

Reveladas as isoenzimas o gel era lavado com água destilada e fixado em solução de glicerina a $10 \%$, por 15 minutos e armazenado em plástico em geladeira. Após esse procedimento, elaborava-se o zimograma desenhando-se as bandas em papel milimetrado, respeitando-se as distâncias entre as bandas e a linha de frente visualizada no gel. Todos os géis foram fotografados para eventuais releituras.

\subsubsection{Interpretação dos zimogramas}

A leitura dos zimogramas eram realizadas a partir de bandas desenhadas em papel milimetrado, guardando-se as dimensões e migrações originais para comparações entre géis e obtenção dos valores de Rf, conforme Alfenas et al.(1991), onde:

$$
\mathrm{Rf}=\mathrm{di} / \mathrm{db}
$$

sendo:

$\mathrm{Rf}=$ valor de referência;

di = distância da origem à banda em questão;

$\mathrm{db}=$ distância da origem até a posição do marcador de bromofenol.

O Rf de cada sistema enzimático foi obtido pela divisão da distância migrada por uma molécula enzimática qualquer (banda presente 
no gel), pela distância migrada pela banda padrão (linha de frente marcador bromofenol). Considerou-se como "banda" as marcas reveladas no gel.

\subsubsection{Análise genético-biométrica dos dados}

Em uma pesquisa, quando se optar por utilização de alguma técnica de análise multivariada, não basta simplesmente adotar um certo programa computacional que execute os cálculos, e delegar ao computador a missão de fornecer todos os resultados. Antes de empregar o computador na análise, é necessário que o pesquisador reflita sobre o tipo de dados disponíveis e entenda o que cada uma das técnicas de análise pode lhe oferecer. É preciso discutir se os dados serão utilizados tal como foram mensurados, ou se devem estar sujeitos a alguma transformação que os tornem mais adequados ao propósito da análise (Curi, 1991).

Seguindo a mesma linha de raciocínio proposta por Curi (1991), os dados bioquímicos foram analisados por diferentes metodologias de taxonomia numérica:

Análise de Agrupamento: os dendrogramas utilizados para a análise da variabilidade genética de roças e regiões, foram fundamentados em matriz de distância calculada pelo programa BIOSYS-1 (Swofford \& Selander, 1989) e usando o algoritmo U.P.G.M.A. (“Unweighted pair-group method with arithmetic average").

Análise de Coordenadas Principais: o padrão isoenzimático codominante dos locos das variedades foi convertido em dado binário 
(presença $=1$ e ausência $=0$ ), então procedeu-se a análise estatística fundamentado na matriz de similaridade obtida com o coeficiente de "Jaccard", e realizada através do programa FITOPAC, versão 1.0, desenvolvido por George John Shepherd da Universidade de Campinas (UNICAMP), Campinas, São Paulo. Os escores das duas primeiras coordenadas principais foram utilizadas para obter o gráfico de dispersão.

Os dendrogramas e o gráfico de dispersão foram feitos utilizando-se o software STATISTICA (STATSOFT Inco., 1996).

O Coeficiente de "Jaccard" utiliza como numerador somente as concordâncias positivas $(\mathrm{J}=\mathrm{a} /(\mathrm{p}-\mathrm{d})$, onde "a" indica as concordâncias positivas (variáveis presentes em ambas as unidade $\mathrm{Xi}$ e $\mathrm{Xi}^{\text {") }}$; "d" as concordâncias negativas (variáveis ausentes em ambas as unidades Xi e $\mathrm{Xi}$ ); e "p" se refere ao conjunto das variáveis estudadas. Quanto maior a semelhança entre as unidades, maior será o valor do coeficiente de associação.

Os dados consistem de "p" variáveis $(\mathrm{a}+\mathrm{b}+\mathrm{c}+\mathrm{d})$ anotados nas unidades Xi e Xi', onde "a" é o número de concordâncias positivas ( Xi $=+\mathrm{e} X \mathrm{i}$ ' $=+$ ), "d" é o número de concordâncias negativas ( $\mathrm{Xi}=-\mathrm{e} \mathrm{Xi}$ ' $=-$ ) , e "b" e "c" indicam as discordâncias $(+-\mathrm{e}-+$, respectivamente). Os sinais $+\mathrm{e}-$ na Tabela 4 para cálculo do coeficiente de associação podem representar presença e ausência de uma estrutura, ou dois estados alternativos quaisquer dos caracteres (Curi, 1991). 
Tabela 4. Cálculo do coeficiente de associação baseado em dados de presença e ausência.

\begin{tabular}{c|c|c}
\hline $\begin{array}{c}\text { UNIDADE } \\
\mathrm{Xi}\end{array}$ & $\begin{array}{c}\text { UNIDADE } \\
\mathrm{Xi}\end{array}$ & TOTAL \\
\hline+ & $\mathrm{a}$ & $\mathrm{a}+\mathrm{b}$ \\
& $\mathrm{b}$ & $\mathrm{c}+\mathrm{d}$ \\
\hline- & $\mathrm{c}$ & $\mathrm{p}$ \\
\hline TOTAL & $\mathrm{d}+\mathrm{c}$ & \multicolumn{2}{|c}{} \\
& $\mathrm{b}+\mathrm{d}$ &
\end{tabular}

onde: $\mathrm{m}=\mathrm{a}+\mathrm{d}=$ concordâncias

$\mathrm{u}=\mathrm{b}+\mathrm{c}=$ discordâncias

$\mathrm{p}=$ conjunto de variáveis

Cada indivíduo de uma amostra multivariada pode ser considerado como um ponto em um Espaço Euclidiano Multidimensional (Curi, 1991). Os processos classificatórios têm por objetivo agrupar esses pontos em conjuntos que mostrem aspectos marcantes da amostra. A Análise de Agrupamento ("Cluster Analysis") é um desses métodos que diante de um conjunto de unidades, conhecidas por uma listagem de seus caracteres, objetiva encontrar a melhor maneira de descrever seus padrões de similaridade mútuas, constituindo classes de indivíduos similares que originarăo os agrupamentos. A técnica de avaliação numérica de afinidade ou de similaridade entre OTU's (Unidades Taxonômicas Operacionais) e de ordenação dessas unidades com base nas suas afinidades foi denominada por Sneath \& Sokal (1973) de Taxonomia Numérica. 
O agrupamento pode ser aglomerativo ou divisivo. No presente estudo, foi utilizado o aglomerativo, que parte de "n" unidades separadas e as agrupam em conjuntos sucessivos até que, na última etapa todas as unidades estejam colocadas em um só conjunto.

O agrupamento aglomerativo, por sua vez, pode ser ou não hierárquico. A estratégia hierárquica foi a utilizada no presente estudo, a qual otimiza um caminho entre a população e os indivíduos que a compõem. Caminho este é definido por fusões progressivas que começam com os indivíduos e terminam com o conjunto todo agrupado. Geralmente as fusões são dicotômicas com os grupos sendo formados aos pares. Como resultado, os agrupamentos maiores serão mais heterogêneos que os menores, e qualquer membro de um grupo com nível hierárquico mais baixo (grupos menores) será também membro de um grupo com nível mais elevado (grupos maiores).

Dentre os principais algoritmos utilizados na Análise de Agrupamento, destaca-se o U.P.G.M.A. (Unweighted Pair Group Method with Arithmetic Average). Segundo Curi (1991), o método não ponderado de agrupamento aos pares usando médias aritméticas é a estratégia mais utilizada.

\subsubsection{Variabilidade genética em plantas.}

\subsubsection{Freqüências alélicas}

Diferentes níveis de variações genéticas são observados entre e dentro de espécies segundo Hamrick \& Godt (1989). A grande variação na 
composição genética e na estrutura da população é fato de extrema importância que deve ser levado em consideração no planejamento de conservação da biodiversidade bem como em estratégias de coleta e amostragens em nível individual ou populacional.

As freqüências alélicas demonstram a variação que ocorre para cada loco analisado. Essas freqüências foram obtidas pela contagem direta do número de alelos por loco, dividindo-se pelo número total de alelos no loco em questão, como segue:

$$
\rho_{\mathrm{ij}}=\mathrm{n}_{\mathrm{ij}} / \mathrm{n}_{\mathrm{j}}
$$

sendo:

$$
\begin{aligned}
& \mathrm{p}_{\mathrm{ij}}=\text { frequência do alelo } \mathbf{i} \text { na roça } \mathbf{j} ; \\
& \mathrm{n}_{\mathrm{ij}}=\text { número de ocorrência do alelo } \mathbf{i} \text { na roça } \mathbf{j} ; \\
& \mathrm{n}_{\mathrm{j}}=\text { número total dos alelos amostrados na roça } \mathbf{j} \text {. }
\end{aligned}
$$

\subsubsection{Estimativas dos índices de diversidade genética}

A partir das freqüências alélicas obteve-se os índices de diversidade genética de Nei (Nei, 1973). Foram feitas estimativas da porcentagem de locos polimórficos $(\mathrm{P})$, número médio de alelos por loco (A) e heterozigosidade médias observada (Ho) para as 23 roças (populações não naturais) estudadas. Tais índices também foram estimados agrupandose as populações por local e por regiões. As estimativas $\mathrm{P}, \mathrm{A}$, e Ho foram obtidas empregando-se o programa BIOSYS-1 (Swofford \& Selander, 1989). 
Os índices de diversidade calculados a partir das freqüências alélicas, permitem obter informações relacionadas ao grau de endogamia dentro das roças.

\section{- Heterozigosidade média observada $\left(\mathrm{H}_{0}\right)$}

A heterozigosidade observada para cada loco foi obtida pela expressão:

$$
\text { Ho }=1-\sum \rho_{\mathrm{ii}}
$$

onde:

$$
\begin{aligned}
& \mathrm{Ho}=\text { heterozigosidade média observada } \\
& \mathrm{p}_{\mathrm{ii}}=\text { frequência dos genótipos homozigotos } .
\end{aligned}
$$

\section{- Porcentagem de locos polimórficos (P)}

O P foi obtido pela média aritmética do número total de alelos dividido pelo número total de locos polimórficos. Foi considerado como polimórfico o loco em que a frequência do alelo mais comum não ultrapassou $95 \%$.

- Número médio de alelos por loco (A)

$\mathrm{O}$ número médio de alelos por loco foi obtido dividindo-se o número total de alelos pelo número total de locos. 


\section{- Coeficiente de diferenciação genética $\left(G_{S T}\right)$}

A distribuição da variabilidade genética foi estimada a partir do coefíciente de diferenciação genética $\mathrm{G}_{\mathrm{ST}}$ (Nei, 1973), onde:

$$
\mathrm{G}_{\mathrm{ST}}=1-\left(\mathrm{H}_{\mathrm{S}} / \mathrm{H}_{\mathrm{T}}\right)
$$

onde:

$$
\begin{aligned}
& \mathrm{H}_{\mathrm{S}}=\text { diversidade média em um loco. } \\
& \mathrm{H}_{\mathrm{T}}=\text { diversidade total no loco. }
\end{aligned}
$$

Sendo: $\mathrm{H}_{\mathrm{T}}$ calculada pela equação:

$$
\mathrm{H}_{\mathrm{T}}=1-\Sigma \mathrm{p}_{\mathrm{i}}^{2}
$$

onde: $\mathrm{p}_{\mathrm{i}}{ }^{2}=$ frequência do i-ésimo alelo no total de plantas.

Sendo: $\mathrm{H}_{\mathrm{S}}$ calculada pela equação:

$$
\mathrm{H}_{\mathrm{S}}=\Sigma \mathrm{nh}_{\mathrm{S}} / \mathrm{N}
$$

onde: $\mathrm{n}=$ número de plantas do grupo.

$\mathrm{N}=$ número total de plantas.

hs = diversidade encontrada num loco em um grupo de

plantas.

Sendo: hS calculada pela equação:

$$
\mathrm{h}_{\mathrm{S}}=2 \mathrm{n}\left(1-\Sigma \mathrm{p}_{\mathrm{i}}^{2}\right) / 2 \mathrm{n}-1
$$

onde: $\mathrm{n}=$ número de plantas do grupo.

$$
\mathrm{p}_{\mathrm{i}}=\text { frequência do i-ésimo alelo desse loco do grupo. }
$$




\subsubsection{Distribuição da variabilidade genética entre e dentro de regiões geográficas}

$O$ índice de fixação de Wright (f) mede o desvio das freqüências genotípicas do equilíbrio de Hardy-Weinberg, o qual não foi avaliado por não se tratar de população natural. Divergência entre populações $\left(\mathrm{G}_{\mathrm{ST}}\right.$ de Nei), foi realizada com base na distribuição dos alelos na população (roça) através da variação na freqüência de cada alelo específico entre as diferentes populações. A estatística $G_{S T}$ de Nei (1973) é uma extensão da estatística F de Wright (1965).

A estatística $G_{S T}$ foi utilizada por não fazer restrições em relação ao modo de reprodução de plantas (sexual ou assexual), que no caso do material genético avaliado provavelmente foi originado por processos de recombinação através de cruzamentos naturais entre as etnovariredades, porém a multiplicação dentro das roças obedece a propagação vegetativa, por meio de manivas. O coeficiente, também, não apresenta restrições para calcular parâmetros genéticos de populações não naturais, caso do presente trabalho.

$$
\mathrm{G}_{\mathrm{ST}}=\mathrm{D}_{\mathrm{ST}} / \mathrm{H}_{\mathrm{T}}
$$

onde:

$$
\begin{aligned}
& \mathrm{G}_{\mathrm{ST}}=\text { divergência genética média entre as populações; } \\
& \mathrm{D}_{\mathrm{ST}}=\text { diversidade genética média entre roças; } \\
& \mathrm{H}_{\mathrm{T}}=\text { diversidade genética total da população. }
\end{aligned}
$$


A estatística $G_{S T}$ de Nei para a caracterização da estrutura genética pode ser utilizada a partir de amostras com pequeno número de indivíduos Nei (1973). 


\section{RESULTADOS E DISCUSSÃO}

\subsection{Procedimentos de eletroforese}

$\mathrm{O}$ tecido de folhas recém expandidas foi o que apresentou melhor resultado. Para obter boa extração em folhas, é necessário utilizar tecidos jovens e pouco lignificados. A solução para extração de proteínas proposta por Scandalios (1969), sem a adição de mercaptoetanol, foi a que apresentou melhor resultado (Ver item 3.2.4.).

As extrações a partir de tecidos foliares resultaram em padrões de bandas nítidas e com boa resolução, com a vantagem de não precisar destruir os indivíduos para realizar a extração, pois somente as folhas recém expandidas foram retiradas permanecendo as plantas intactas para futuras avaliações e acompanhamentos, tanto de campo como de laboratório.

Os resultados obtidos com os 11 sistemas enzimáticos analisados nos três sistemas diferentes de tampões de eletrodo e gel mostraram boa resolução, sendo que o sistema $\mathrm{CM}$ (citrato morfolina) foi o que permitiu analisar o maior número de sistemas. 


\subsection{Padrões de isoenzimas.}

Ramirez et al. (1987) apresentaram protocolo desenvolvido para M. esculenta Crantz. Preliminarmente, este foi testado, mas com pouco sucesso para as condições do nosso laboratório e material utilizado. Os autores utilizaram plântulas com dois meses de idade e, neste trabalho, foram utilizados materiais com mais de doze meses de idade.

Outras metodologias de corridas para eletroforese de enzimas são encontradas na literatura, tais como os protocolos de Lefèvre \& Charrier (1993a), desenvolvidos para M. esculenta e M. glaziovii, e os de Hussain et al. (1987) também para M. esculenta. Todavia, os protocolos que melhores resultados apresentaram foram os que utilizaram o sistema-tampão tris citrato (TC) de Soltis et al. (1983); sistema-tampão citrato-morfolina (CM), de Clayton \& Tretiak (1972); e sistema-tampão AB segundo Wendel \& Weenden (1990).

A maioria dos sistemas enzimáticos estudado em $M$. esculenta Crantz, parece apresentar padrões uniformes de bandas quando é utilizado folhas em estádios diferentes de idade da planta. Somente o sistema das alfa-esterases apresentou variação de bandas, de acordo com o estádio de desenvolvimento da folha. As alterações que ocorrem com a esterase podem ser decorrente da presença de substrato não específico, por essa razão, esse sistema não foi utilizado.

No Laboratório de Genética Ecológica do Departamento de Genética da ESALQ-USP, foi estabelecido protocolo para eletroforese de isoenzimas em mandioca (M. esculenta Crantz), como pode ser verificado 
em Faraldo (1994), Peroni (1998), Sambatti (1998) e Silva (1999). Dessa forma, ficará mais fácil trabalhar com a cultura e, principalmente, com as espécies selvagens do gênero Manihot.

Com base nos resultados obtidos para os sistemas enzimáticos testados, optou-se por utilizar 11 sistemas (AAT, CAP, MDH, MADH, SKDH, PGI, ME, ACP, G6PDH, IDH e PGM), que apresentaram os melhores padrões de zimogramas, para o tecido em estudo. O sistema enzimático glutamato desidrogenase (GTDH) foi descartado por não apresentar a forma heterozigota dos indivíduos, conforme Silva (1999), embora apresentasse polimorfismo isoenzimático.

Os zimogramas obtidos com os 11 sistemas analisados sugerem a existência de 15 locos polimórficos, cujos padrões fenotípicos podem ser observados nas figuras 1 a 12 .

\section{- Aspartato aminotransferase (AAT- E.C. 2.6.1.1)}

O padrão de resolução apresentado por essa enzima foi muito bom. Foram encontrados dois locos, porém apenas um loco foi analisado (Aat-1), com atividade bastante intensa. Segundo Khephart (1990), estruturalmente a enzima é formada por duas subunidades polipeptídicas (enzima dimérica), contudo, no presente trabalho, o loco específico comportou-se como enzima monomérica (duas bandas no heterozigoto). $\mathrm{O}$ sistema apresentou três padrões fenotípicos diferentes (Figura 1).

- Citosol aminopeptidase (CAP - E.C. 3.4.11.1)

Este sistema enzimático caracterizou-se por apresentar 3 locos enzimáticos (Cap-1, Cap-2 e Cap-3), totalizando 7 bandas no gel com 
atividade bastante intensa. Desses três locos detectados apenas o loco Cap-I foi usado nas análises. O loco Cap-2 comportou-se como marcador dominante. O terceiro loco que seria denominado de Cap-3 caso tivesse sido analisado, não o foi por não apresentar nitidez das bandas. A enzima comportou-se como monomérica (duas bandas no heterozigoto). O padrão fenotípico característico de um heterozigoto é representado por duas bandas isoenzimáticas (a mais lenta e a mais rápida dentro do mesmo loco). Foram observados três padrões fenotípicos distintos (Figura 2).

\section{- Malato desidrogenase (MDH - E.C. 1.1.1.37)}

A enzima apresentou boa atividade no tecido estudado sendo que os padrões de bandas obtidos a partir de folhas recém expandidas foram excelentes. O sistema enzimático apresentou três locos (Mdh-l, Mdh-2 e Mdh-3), sendo que os locos $M d h-2$ e $M d h-3$ eram aparentemente monomórficos, em decorrência da falta de certeza no número de locos, a região foi retirada das análises. A enzima $\mathrm{MDH}$ é dimérica, sendo que o loco Mdh-l apresentou uma a três bandas. O fenótipo do indivíduo heterozigoto observado no zimograma apresentou três bandas. Foram observaodos três fenótipos (Figura 3).

\section{- Manitol desidrogenase (MADH - E.C. 1.1.1.67)}

O sistema enzimático manitol desidrogenase ocorre em folhas recém expandidas de plantas com até um ano de idade, não apresentando padrões diferentes durante todo esse período, ou seja, esta enzima se mantém com atividade constante. O heterozigoto apresenta um padrão 
monomérico ( 1 subunidade polipeptídica) e se caracteriza pela presença de duas bandas. O sistema apresentou três fenótipos distintos (Figura 4).

\section{- Glutamato desidrogenase (GTDH - E.C. 1.4.1.3)}

O sistema enzimático não foi considerado na análise por apresentar padrão não esperado, no sentido de que todos os indivíduos amostrados apresentarem-se em homozigose, não sendo observados indivíduos heterozigotos. É curioso que, para esse sistema, o padrão da banda apresentado é preservado em qualquer estádio de desenvolvimento da planta, podendo ser um ótimo marcador bioquímico na caracterização de germoplasma. Contudo, há necessidade de descobrir qual o motivo da ausência de detecção de indivíduos heterozigotos. Segundo Hillis et al. (1995), é um problema relacionado com a migração da enzima e não com a resolução apresentada no gel. O fenômeno também foi constatado por Peroni (1998) e Silva (1999). O sistema enzimático, geralmente, é polimórfico. O sistema apresentou três fenótipos distintos (Figura 5).

\section{- Xiquimato desidrogenase (SKDH - E.C. 1.1.1.25)}

Esta enzima apresentou um loco enzimático, o $S k d h-I$ com 4 alelos. A enzima comportou-se como monomérica (duas bandas no heterozigoto). A atividade enzimática foi bastante intensa para todas as variedades. O número de bandas apresentado por indivíduo variou de 1 a 2 bandas, conforme a variedade. O sistema apresentou dez fenótipos diferentes (Figura 6). 


\section{- Fosfoglucose isomerase (PGI - E.C. 5.3.1.9)}

O sistema da fosfoglucose isomerase mostrou atividade enzimática intensa no tecido utilizado. A enzima apresentou-se monomérica para o loco Pgi-l e dimérica para o loco Pgi-2 como pode ser comprovado na Figura 7. O loco Pgi-l caracterizou-se por possuir uma ou duas bandas no gel, sendo considerados heterozigotos os indivíduos portadores de duas bandas e homozigotos os que apresentaram uma banda. Oito fenótipos foram detectados nesse sistema (Figura 7).

\section{- Enzima málica (ME - E.C. 1.1.1.40)}

Este sistema caracterizou-se por apresentar dois locos enzimáticos (Me-l e Me-2) e sete fenótipos distintos. Do ponto de vista estrutural, a enzima comportou-se como monomérica (duas bandas no heterozigoto) (Figura 8).

- Glucose-6-fosfato desidrogenase (G6PDH - E.C. 1.1.1.49).

Este sistema enzimático caracterizou-se por apresentar dois locos isoenzimáticos: G6pdh-1 e G6pdh-2. Da mesma forma que o sistema enzimático fosfoglucose isomerase, esta enzima apresentou um loco (G6pdh-l) monomérico e o outro dimérico (G6pdh-2). Nove fenótipos foram observados no gel (Figura 9).

- Fosfatase ácida (ACP - E.C. 3.1.3.2)

A fosfatase ácida mostrou atividade enzimática intensa no tecido foliar usado nas análises, sugerindo ser alto o nível dessa enzima em 
folhas de mandioca. Este sistema apresentou dois locos enzimáticos (Acp-l e $A c p-2)$ e nove fenótipos distintos. Trata-se de uma enzima monomérica (Figura 10).

\section{- Isocitrato desidrogenase (IDH - E.C. 1.1.1.42)}

A enzima isocitrato desidrogenase comportou-se como monomérica, mostrando um loco $(I d h-I)$ com duas bandas. O padrão fenotípico observado nos indivíduos heterozigotos é representado por duas bandas. Três fenótipos foram identificados no gel (Figura 11).

\section{- Fosfoglucomutase (PGM - E.C. 2.7.5.1)}

Como a maioria das enzimas avaliadas neste trabalho, a fosfoglucomutase apresentou-se como enzima monomérica, com uma ou duas bandas visualizadas no gel, duas marcas quando tratava-se do indivíduo heterozigoto e uma quando do homozigoto. Esse sistema apresentou três fenótipos diferentes (Figura 12).

As Figuras 1 a 12 ilustram, esquematicamente, os padrões eletroforéticos observados nos géis que permitiram análise não duvidosa e cujos locos foram determinados a partir dos Rf (valores de referência), conforme recomendações de Alfenas et al. (1991), para os onze sistemas enzimáticos analisados. Foram detectados 37 alelos em 15 locos e 60 padrões fenotípicos diferentes na 138 etnovariedades e variedade Mantiqueira. 


\subsection{Interpretação genética dos zimogramas}

$\mathrm{Na}$ literatura existem poucos trabalhos que apresentam padrões genéticos que utilizam a técnica da eletroforese de enzimas em espécies do gênero Manihot, quando comparada com outras culturas como milho, algodão, etc. Entre os autores que realizaram estudos dessa natureza podemos destacar Ramirez et al. (1987), Hussain et al. (1987), Lefèvre \& Charrier (1993), Faraldo (1994), Borsoi Filho (1995), Peroni (1998) e Sambatti (1998).

Os padrões de zimogramas encontrados, no presente estudo, são semelhantes aos descritos por Lefèvre \& Charrier (1993), que propuseram três níveis de interpretação para o sistema enzimático da malato desidrogenase $(\mathrm{MDH})$ : os níveis A e B foram interpretados como produtos de um único gene, representado por uma única banda no gel, com padrão monomórfico; e o nível $\mathrm{C}$ foi considerado como produto dimérico de um único gene ( 1 a 3 bandas). De maneira geral, a mandioca cultivada (Manihot esculenta Crantz) apresenta 3 locos isoenzimáticos para $\mathrm{MDH}$. Do ponto de vista estrutural, esta enzima apresenta configuração molecular dimérica, sem bandas entre os locos.

Por outro lado, os resultados apresentados por Borsoi Filho (1995), que trabalhou com diferentes cultivares de mandioca, mostraram duas regiões de atividades enzimáticas para o sistema $\mathrm{MDH}$. A região considerada mais rápida, denominada $M d h-l$, sugere ser um único loco com três bandas, enquanto que a região mais lenta, denominada de $M d h-2$, o 


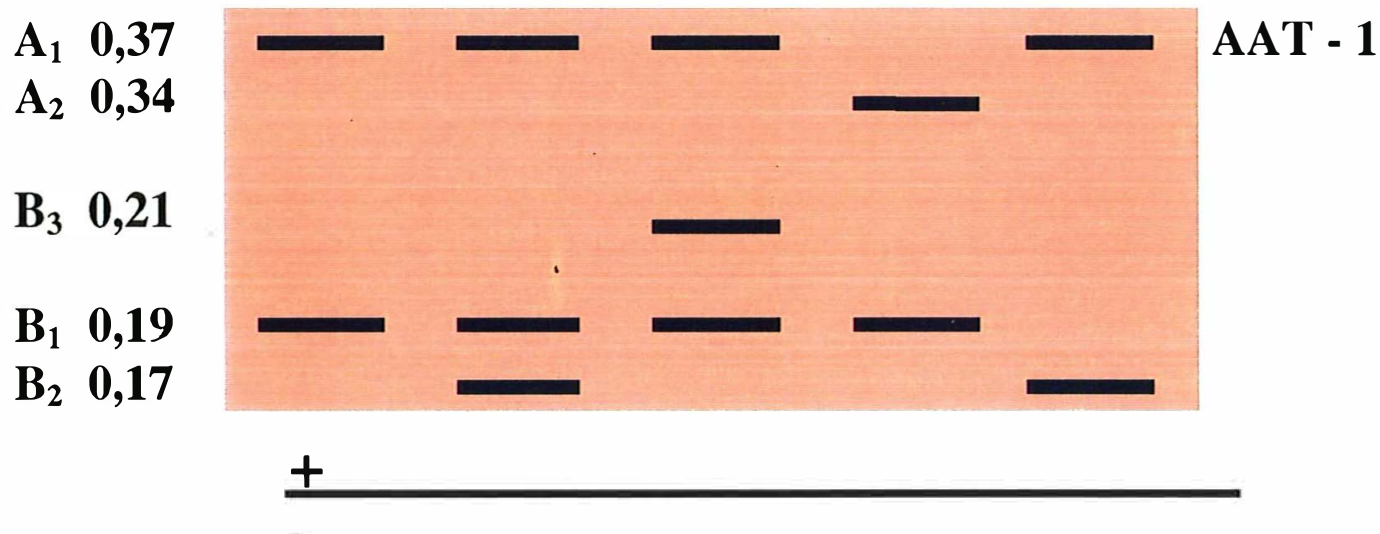

Figura 1. Zimograma dos padrões eletroforéticos apresentando os fenótipos do sistema enzimático da aspartato aminotransferase (AAT), analisados em folhas recém expandidas de vinte e três roças de $M$. esculenta do Brasil, com seus respectivos locos, alelos e valores de referência.

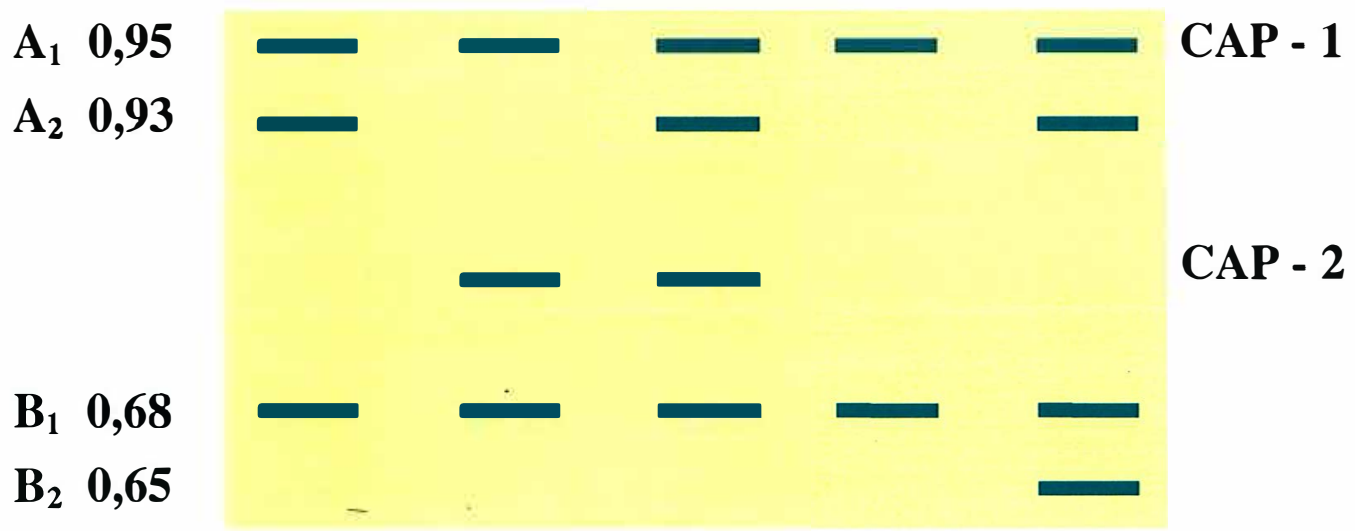

$\pm$

Figura 2. Zimograma dos padrões eletroforéticos apresentando os fenótipos do sistema enzimático da citosol aminopeptidade (CAP), analisados em folhas recém expandidas de vinte e três roças de $M$. esculenta do Brasil, com seus respectivos locos, alelos e valores de referência. 


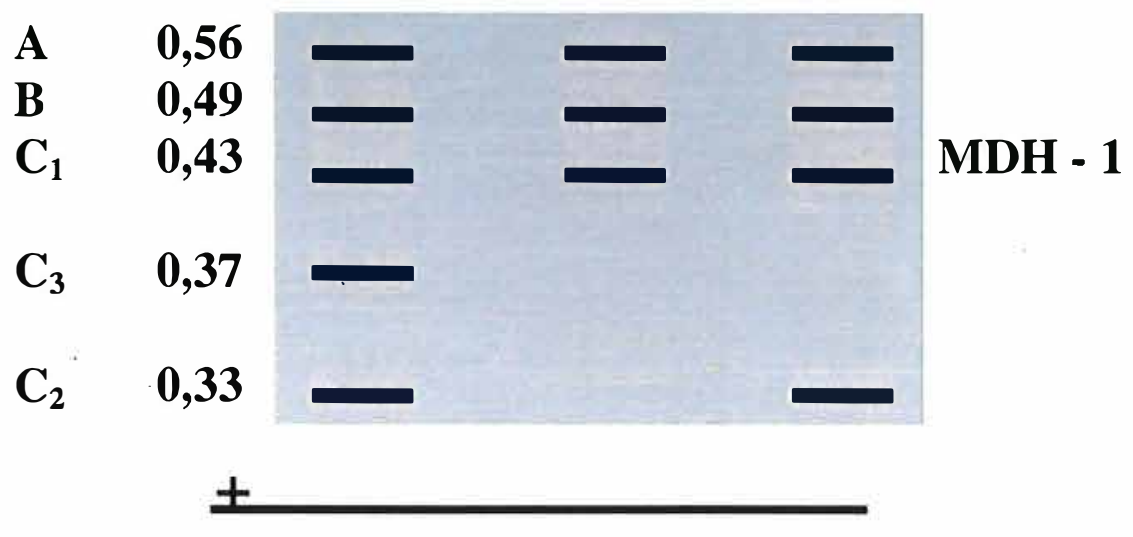

Figura 3. Zimograma dos padrões eletroforéticos apresentando os fenótipos do sistema enzimático da malato desidrogenase (MDH), analisados em folhas recém expandidas de vinte e três roças de $M$. esculenta do Brasil, com seus respectivos locos, alelos e valores de referência.

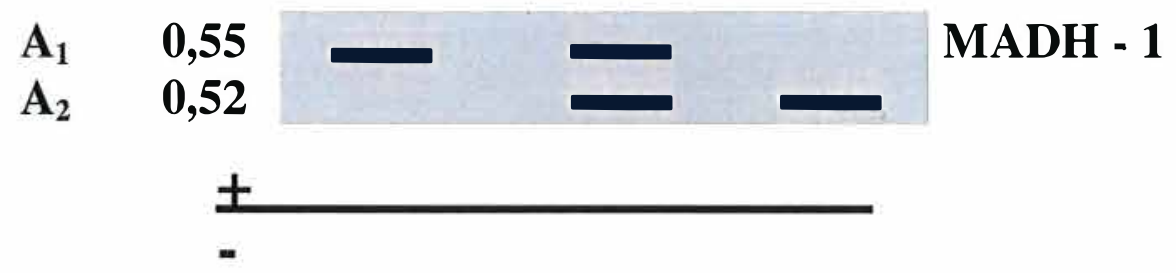

Figura 4. Zimograma dos padrões eletroforéticos apresentando os fenótipos do sistema enzimático da manitol desidrogenase (MADH), analisados em folhas recém expandidas de vinte e três roças de $M$. esculenta do Brasil, com seus respectivos locios, alelos e valores de referência. 


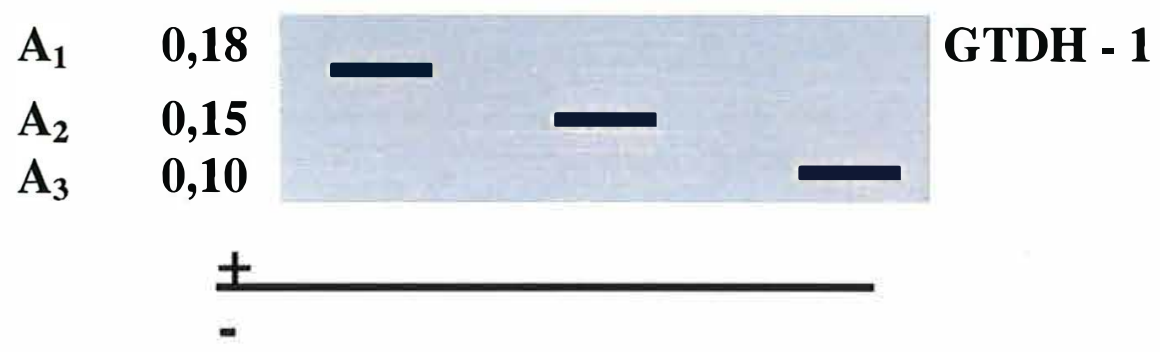

Figura 5. Zimograma dos padrões eletroforéticos apresentando os fenótipos do sistema enzimático da glutamato desidrogenase (GTDH), analisados em folhas recém expandidas de vinte e três roças de $M$. esculenta do Brasil, com seus respectivos locos, alelos e valores de referência.

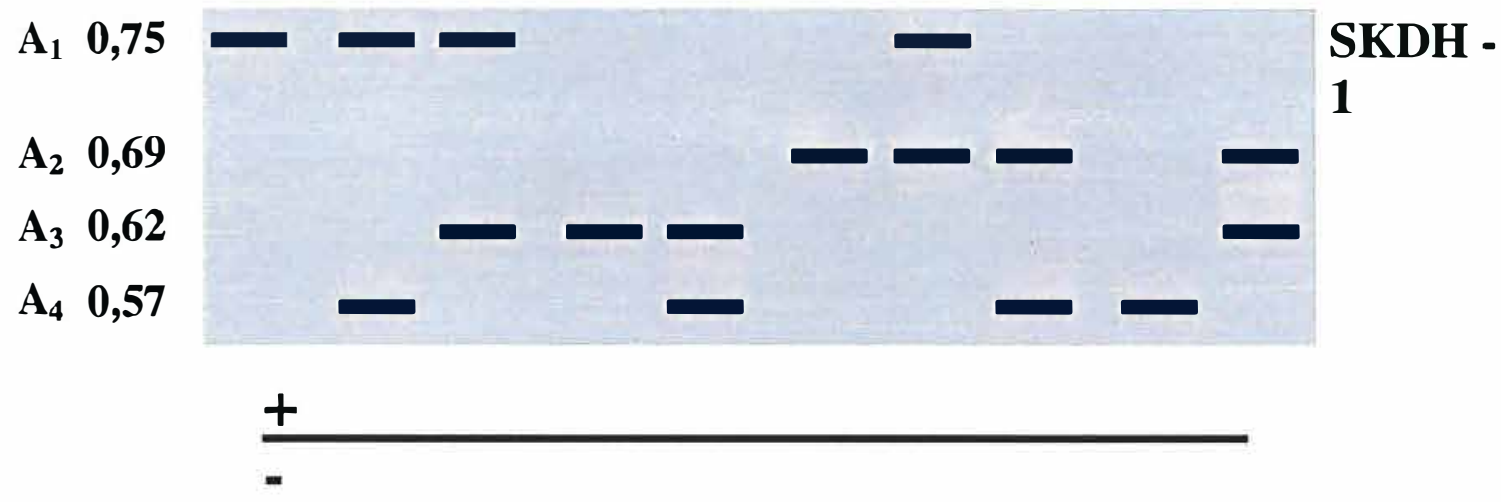

Figura 6. Zimograma dos padrões eletroforéticos apresentando os fenótipos do sistema enzimático da xiquimato desidrogenase (SKDH), analisados em folhas recém expandidas de vinte e três roças de M. esculenta do Brasil, com seus respectivos locos, alelos e valores de referência. 


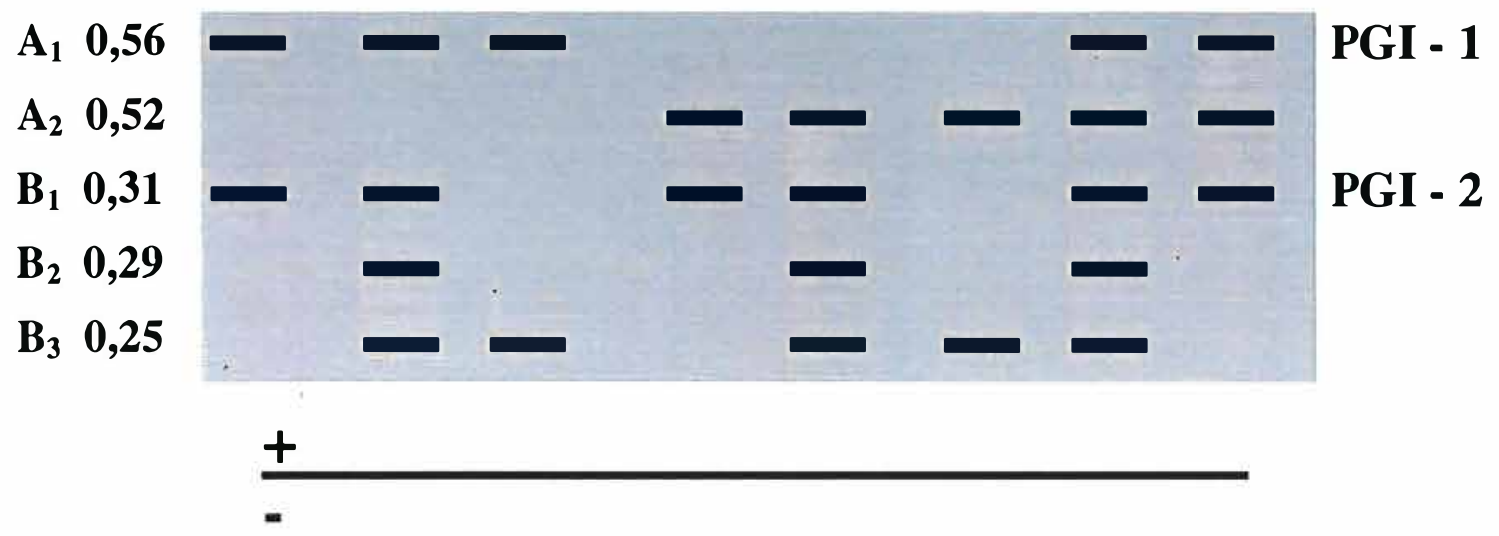

Figura 7. Zimograma dos padrões eletroforéticos apresentando os fenótipos do sistema enzimático da fosfoclucose isomerase (PGI), analisados em folhas recém expandidas de vinte e três roças de $M$. esculenta do Brasil, com seus respectivos locos, alelos e valores de referência.

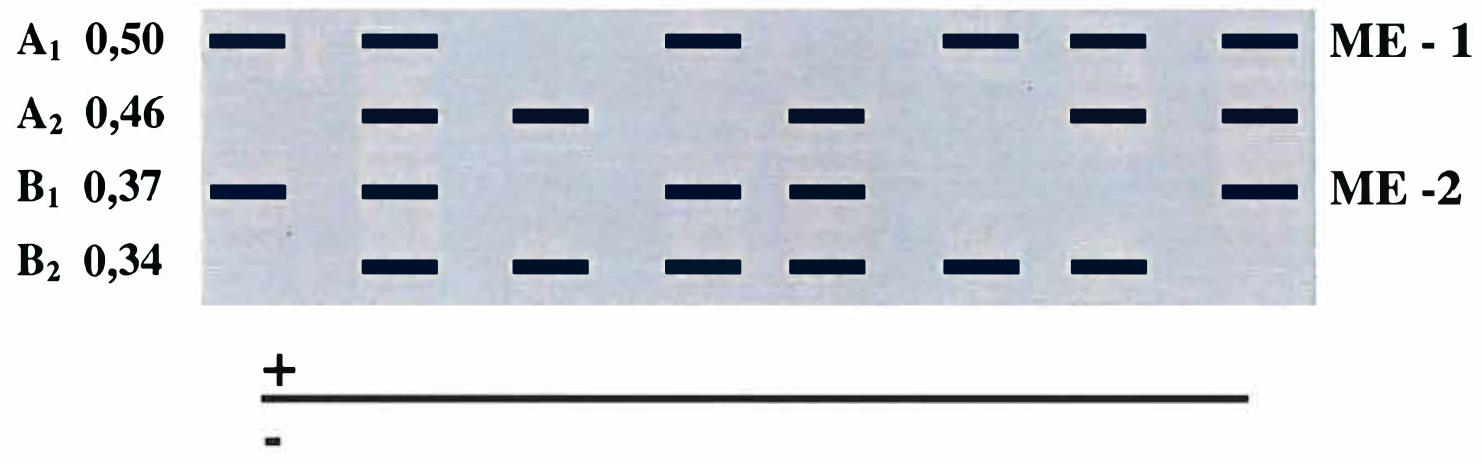

Figura 8. Zimograma dos padrões eletroforéticos apresentando os fenótipos do sistema enzimático da enzima málica (ME), analisados em folhas recém expandidas de vinte e três roças de $M$. esculenta do Brasil, com seus respectivos locos, alelos e valores de referência. 


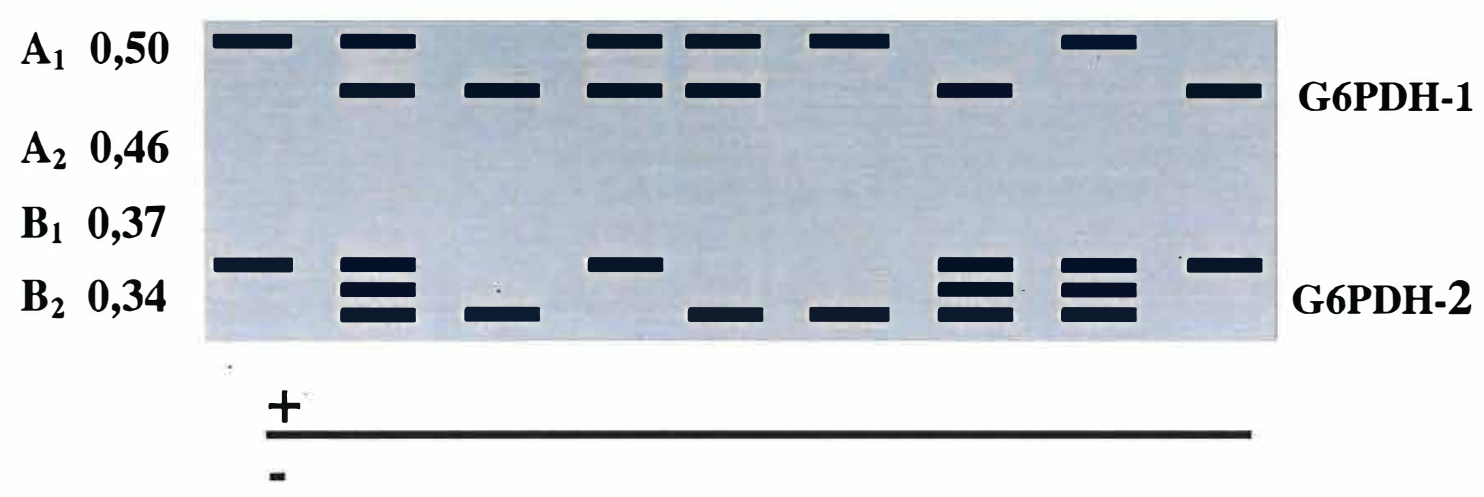

Figura 9. Zimograma dos padrões eletroforéticos apresentando os fenótipos do sistema enzimático da glucose-6-fosfato desidrogenase (G6PDH), analisados em folhas recém expandidas de vinte e três roças de M. esculenta do Brasil, com seus respectivos locos, alelos e valores de referência.

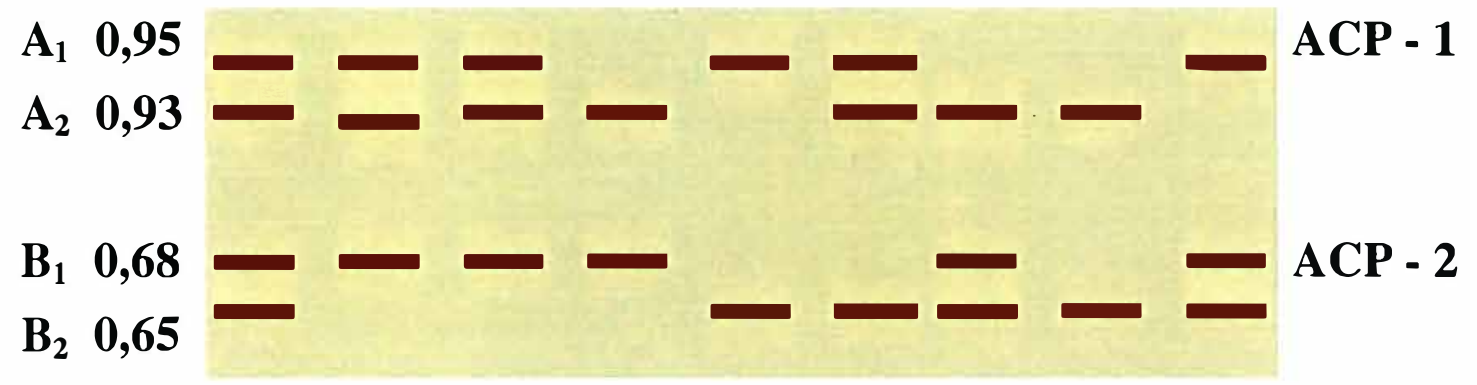

$\pm$

Figura 10. Zimograma dos padrões eletroforéticos apresentando os fenótipos do sistema enzimático da fosfatase ácida (ACP), analisados em folhas recém expandidas de vinte e três roças de M. esculenta do Brasil, com seus respectivos locos, alelos e valores de referência. 


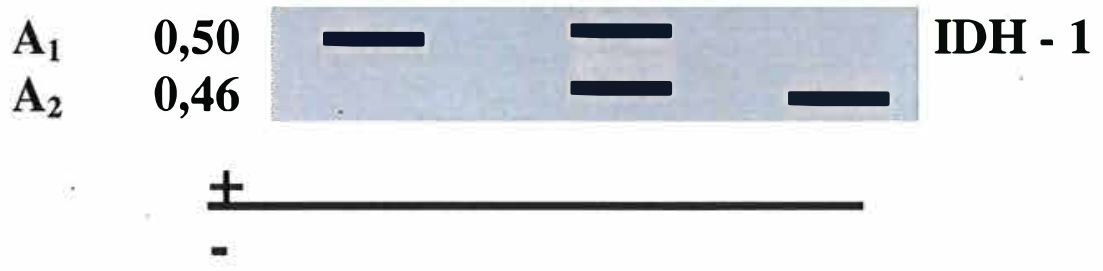

Figura 11. Zimograma dos padrões eletroforéticos apresentando fenótipos do sistema enzimático Isocitrato desidrogenase (IDH), analisados em folhas recém expandidas de vinte e três roças de Manihor esculenta do Brasil, com seus respectivos locos, alelos e valores de referência.

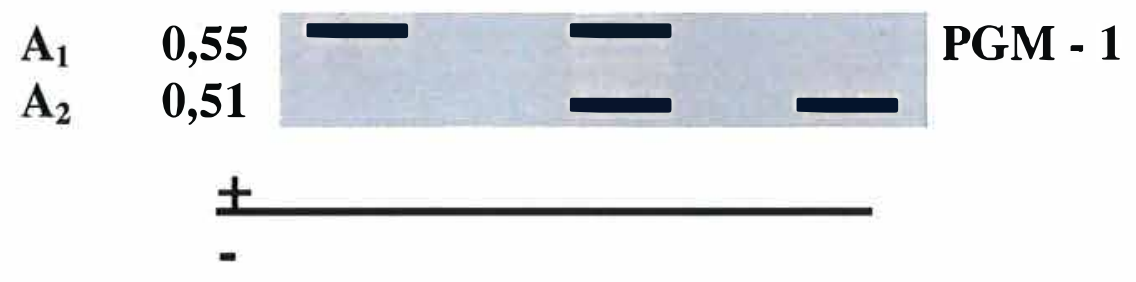

Figura 12. Esquema do zimograma dos padrões eletroforéticos apresentando fenótipos do sistema enzimático fosfoclucose isomerase (PGI) analisados me folhas recém expandidas de vinte e três rocas de Manihot esculenta do Brasil, com seus respectivos locos, alelos e valores de referência. 
autor suspeita existir mais de um loco, com um total de quatro bandas. A interpretação enzimática dada pelo autor está em discordância com aquelas apresentadas por Lefèvre \& Charrier (1993) e, no presente trabalho, quanto ao número de alelos por loco, e número de locos obtidos. No caso do presente estudo, o resultado encontrado foi superior ao observado por Borsoi Filho (1995), apresentando, portanto, maior variabilidade genética nas populações analisadas.

A complexidade da interpretação genética da enzima $\mathrm{MDH}$ (malato desidrogenase), normalmente, tem levado os pesquisadores analisarem um e no máximo dois locos para esse sistema (Khephart, 1990).

A interpretação dos sistemas enzimáticos sugerida, no presente estudo, está de acordo com os padrões eletroforéticos encontrados por Silva (1999), que avaliou 55 etnovariedades e progênies, das 138 analisadas, no presente trabalho, o que torna a interpretação extremamente segura. $\mathrm{O}$ autor estudou o material genético em gel de poliacrilamida em gradiente, sistema bastante refinado e que dificilmente deixa dúvidas na interpretação.

Silva (1999) sugere que o sistema citosol aminopeptidase (CAP) em gel de poliacrilamida, pode ser usado na identificação de cultivares de mandioca, por apresentar padrões isoenzimáticos específicos de acordo com o genótipo analisado e herança dominante. Segundo o autor, esse sistema poderia ser usado como marcador para selecionar variedades e na identificação de rotina de variedades de mandioca. $\mathrm{O}$ mesmo fato foi comprovado, no presente estudo, utilizando gel de amido de milho (penetrose 30 a 13\%). 
Para o sistema da xiquimato desidrogenase (SKDH - E.C. 1.1.1.25), foi constatado a presença de um único loco gênico ( $S k d h-I)$ com 4 alelos. Lefèvre \& Charrier (1993) também observaram a presença de um único loco gênico, monomérico, com 6 alelos, em M. esculenta, dois alelos a mais que o presente trabalho, possivelmente, em decorrência de terem trabalhado com maior número de acessos.

Peroni (1998) também encontrou quatro bandas, as quais ele separou em dois grupos A e B por ter a banda número 4 se mostrado inconstante no decorrer das análises, cuja justificativa ficou por conta da idade diferenciada do material genético. Sambatti (1998) encontrou 5 bandas polimórficas para o sistema $\mathrm{SKDH}$.

Alguns autores como Hodgkin et al. (1993) e Borejevic (1990), citados por Cleveland et al. (1994), caracterizam a variação genética encontrada nos materiais provenientes de agricultura tradicional, pela presença de vários alelos por loco, por indivíduo, resultando em elevados níveis de heterozigosidade. Dessa forma, o sistema xiquimato desidrogenase (SKDH - E.C.1.1.1.25), analisado confirma a premissa relatada pelos autores, por apresentar um único loco com 4 alelos.

Lefèvre \& Charrier (1993a), estudando a herança genética de 17 locos isoenzimáticos em M. esculenta Crantz, apresentaram padrões isoenzimáticos diferentes dos observados, no presente estudo, para o sistema da citosol aminopeptidase. Os autores encontraram apenas um loco gênico $(A m p-A)$ com 3 alelos $\left(\mathrm{A}_{1}, \mathrm{~A}_{2}\right.$ e $\left.\mathrm{A}_{3}\right)$. Em contrapartida, Silva (1999) não constatou esse resultado trabalhando em gel de poliacrilamida. 
O sistema da aspartato aminotransferase (AAT - E.C. 2.6.1.1) apresentou dois locos gênicos (Aat- I e Aat-2). O loco Aat-I apresentou 2 alelos e o loco Aat-2 parecia ter 3 alelos, porém não apresentou resolução que possibilitasse interpretação. A estrutura enzimática da AAT é dimérica de acordo com as citações de Lefèvre \& Charrier (1993) e Khephart (1990).

Os padrões de zimogramas encontrados no sistema AAT, do presente estudo, são relativamente similares aos padrões observados em $M$. esculenta por Lefèvre \& Charrier (1993), com exceção do loco Aat-A, que apresentou um único alelo.

O sistema da aspartato aminotransferase (AAT) mostrou ser importante como marcador bioquímico na identificação de cultivares da mandioca (M. esculenta). Esse resultado está de acordo com as citações de Ramirez et al. (1987) que também reconheceram o sistema da GOT ou AAT como um marcador molecular em potencial, para o material cultivado.

Por outro lado, Borsoi Filho (1995), sugere não haver variação intraclonal dos padrões isoenzimáticos em cultivares de $M$. esculenta por ele estudado para o sistema glutamato oxalacético transaminase (GOT ou AAT). O autor não considera o sistema enzimático da GOT como um marcador bioquímico em potencial, discordando dos autores acima.

Pequenas variações na interpretação e resolução das enzimas podem refletir nas estimativas comprometendo a representatividade, principalmente no que se refere a comparação entre espécies diferentes (Simon \& Archie, 1985). 
A inclusão ou não de locos monomórficos nas estimativas de diversidade deve ser considerada, pois na medida que locos tomados ao acaso revelam certa quantidade de locos monomórficos, haverá maior possibilidade de representatividade com a inclusão dos mesmos. No presente estudo, estes não foram incluídos nas análises, pois produziram viés expressivo mostrando efeitos de grande magnitude nas estimativas de diversidade.

\subsection{Variação genética}

$\mathrm{Na}$ Tabela 5, observam-se as freqüências alélicas dos 15 locos isoenzimáticos obtidos nos onze sistemas enzimáticos de $M$. esculenta, pertencentes a vinte e três roças (populações clonais) de diferentes regiões geográficas do Brasil.

$\mathrm{Na}$ Tabela 5, observam-se valores que variam desde $4,5 \%$ a $100 \%$ (alelo fixado). $\mathrm{O}$ alelo $\mathrm{A}_{4}$ do $S k d h-1$ da roça 8 e o alelo $\mathrm{A}_{2}$ do loco Pgm-1 da roça 18. Com relação ao locos fixados destacam-se os da Cap-l nas roças 6 e 22; Mdh-l nas roças 1, 2, 3, 6, 9, 10, 11, 12, 22 e 23, praticamente $45 \%$ das roças amostradas apresentaram-se fixadas para 0 alelo $\mathrm{A}_{1}$ desse loco; Madh-1 nas roças 17, 19 e 21; Pgi-l nas roças 1, 11, $14,16,19$ e 23, sendo que somente a roça 23 apresentou o alelo $A_{2}$ fixado; Pgi-2 nas roças 1 e 7; Me-2 na roça 22; $A c p-1$ nas roças $1,5,6,15,16,19$, 22 e 23; $A c p-2$ nas roças 1, 6, 7, 11, 22 e 23; G6pdh-1 na roça 22; G6pdh-2 nas roças 6, 10, 11 e 23; Idh-l nas roças 5, 6, 10, 11 e 19; e Pgm-l na roça 6. 
Tabela 5. Freqüência alélica para 15 locos isoenzimáticos nas 23 roças (populações) de etnovariedades de M. esculenta.

\begin{tabular}{|c|c|c|c|c|c|c|c|c|}
\hline \multirow[b]{2}{*}{ Locos } & \multicolumn{8}{|c|}{ Populacões } \\
\hline & 1 & 2 & 3 & 4 & 5 & 6 & 7 & 8 \\
\hline $\begin{array}{l}\text { Aat-l } \\
(\mathrm{N})\end{array}$ & 2 & 6 & 3 & 14 & 4 & 2 & 3 & 11 \\
\hline $\mathrm{A}_{1}$ & 0,500 & 0,667 & 0,500 & 0,714 & 0,625 & 0.500 & 0,167 & 0,500 \\
\hline $\mathrm{A}_{2}$ & 0,500 & 0,333 & 0,500 & 0,286 & 0,375 & 0,500 & 0.833 & 0.500 \\
\hline Cap-I & & & & & & & & \\
\hline $\mathrm{A}_{\mathrm{I}}$ & 0,750 & 0.417 & 0,000 & 0,429 & 0,875 & 1,000 & 0,333 & 0,727 \\
\hline $\begin{array}{l}\mathrm{A}_{2} \\
M d h-1\end{array}$ & 0,250 & 0,583 & 1,000 & 0,571 & 0,125 & 0,000 & 0,667 & 0.273 \\
\hline$A_{3}$ & 1,000 & 1,000 & 1,000 & 0,929 & 0,875 & 1,000 & 0,833 & 0,864 \\
\hline $\begin{array}{l}\mathrm{A}_{2} \\
\text { Madh-l }\end{array}$ & 0,000 & 0,000 & 0,000 & 0,071 & 0,125 & 0,000 & 0.167 & 0,136 \\
\hline $\mathrm{A}_{\mathrm{I}}$ & 0,750 & 0,417 & 0.667 & 0.857 & 0.625 & 0.750 & 0.667 & 0,682 \\
\hline $\begin{array}{l}\mathrm{A}_{2} \\
\text { Skdh-1 }\end{array}$ & 0.250 & 0.583 & 0,333 & 0,143 & 0,375 & 0,250 & 0.333 & 0,318 \\
\hline$A_{1}$ & 0,000 & 0,583 & 0,667 & 0,679 & 0,250 & 0,000 & 0.667 & 0,182 \\
\hline $\mathrm{A}_{2}$ & 0,750 & 0,167 & 0,000 & 0,071 & 0,375 & 0.500 & 0,000 & 0,591 \\
\hline $\mathrm{A}_{3}$ & 0,000 & 0,083 & 0,000 & 0,071 & 0,000 & 0,000 & 0,000 & 0,182 \\
\hline $\begin{array}{l}\mathrm{A}_{4} \\
P g i-1\end{array}$ & 0,250 & 0,167 & 0,333 & 0,179 & 0,375 & 0,500 & 0,333 & 0,045 \\
\hline$A_{1}$ & 1,000 & 0,500 & 0,333 & 0,429 & 0,500 & 0,500 & 0,667 & 0,727 \\
\hline $\begin{array}{l}\mathrm{A}_{2} \\
P g i-2\end{array}$ & 0,000 & 0,500 & 0,667 & 0,571 & 0,500 & 0,500 & 0,333 & 0,273 \\
\hline $\mathrm{B}_{1}$ & 1,000 & 0.417 & 0,333 & 0,464 & 0.375 & 0.250 & 1.000 & 0,455 \\
\hline $\begin{array}{l}\mathrm{B}_{2} \\
M e-1\end{array}$ & 0,000 & 0,583 & 0.667 & 0,536 & 0,625 & 0,750 & 0.000 & 0,545 \\
\hline$A_{l}$ & 0,500 & 0,583 & 0,667 & 0.607 & 0.750 & 0,500 & 0.500 & 0,591 \\
\hline $\begin{array}{l}\mathrm{A}_{2} \\
M e-2\end{array}$ & 0,500 & 0.417 & 0,333 & 0.393 & 0.250 & 0,500 & 0.500 & 0.409 \\
\hline$A_{I}$ & 0.500 & 0.333 & 0,500 & 0.679 & 0.500 & 0.500 & 0.500 & 0.591 \\
\hline $\begin{array}{l}\mathrm{A}_{2} \\
A c p-1\end{array}$ & 0,500 & 0,667 & 0.500 & 0.321 & 0,500 & 0,500 & 0,500 & 0,409 \\
\hline$A_{1}$ & 0,000 & 0,667 & 0,167 & 0.500 & 0,000 & 0.000 & 0,833 & 0,182 \\
\hline $\begin{array}{l}\mathrm{A}_{2} \\
\text { Acp-2 }\end{array}$ & 1.000 & 0,333 & 0,833 & 0,500 & 1.000 & 1,000 & 0,167 & 0,818 \\
\hline $\mathrm{A}_{\mathrm{I}}$ & 0,000 & 0,500 & 0,167 & 0.321 & 0.250 & 0.000 & 0.000 & 0,636 \\
\hline $\begin{array}{l}\mathrm{A}_{2} \\
\text { G6pdh-I }\end{array}$ & 1,000 & 0.500 & 0,833 & 0,679 & 0.750 & 1,000 & 1,000 & 0,364 \\
\hline$A_{1}$ & 0,250 & 0.750 & 0.500 & 0.571 & 0.500 & 0.500 & 0.500 & 0.545 \\
\hline $\begin{array}{l}\mathrm{A}_{2} \\
\text { G6pdh-2 }\end{array}$ & 0,750 & 0.250 & 0,500 & 0,429 & 0.500 & 0.500 & 0.500 & 0.455 \\
\hline $\mathrm{B}_{\mathrm{I}}$ & 0,500 & 0,750 & 0,667 & $0.71 t$ & 0.875 & 1.000 & 0.500 & 0.909 \\
\hline $\begin{array}{l}\mathrm{B}_{2} \\
\text { Idh-I }\end{array}$ & 0,500 & 0,250 & 0.333 & 0.286 & 0.125 & 0.000 & 0.500 & 0.091 \\
\hline$A_{I}$ & 0.500 & 0.833 & 1,000 & 0.857 & 1.000 & 1.000 & 0.667 & 0,909 \\
\hline $\mathrm{A}_{2}$ & 0,500 & 0,167 & 0,000 & 0.143 & 0.000 & 0,000 & 0,333 & 0,091 \\
\hline
\end{tabular}




\begin{tabular}{|c|c|c|c|c|c|c|c|c|}
\hline \multirow[b]{2}{*}{ Locos } & \multicolumn{8}{|c|}{ Populações } \\
\hline & 9 & 10 & 11 & 12 & 13 & 14 & 15 & 16 \\
\hline \multicolumn{9}{|l|}{$P g m-1$} \\
\hline $\mathrm{A}_{1}$ & 0.500 & 0.500 & 0.667 & 0,750 & 0.625 & 0,000 & 0,333 & 0,500 \\
\hline $\begin{array}{l}\mathrm{A}_{2} \\
\text { Aat-1 }\end{array}$ & \multicolumn{7}{|c|}{ Aat -1} & 0,500 \\
\hline$(\mathrm{N})$ & 7 & 2 & 2 & 3 & 6 & 6 & 7 & 5 \\
\hline $\mathrm{A}_{1}$ & 0,429 & 0,250 & 0.500 & 0,833 & 0.417 & 0,667 & 0.571 & 0,300 \\
\hline $\mathrm{A}_{2}$ & 0,571 & 0.750 & 0,500 & 0,167 & 0.583 & 0,333 & 0,500 & 0,600 \\
\hline \multicolumn{9}{|l|}{ Cap-1 } \\
\hline $\mathrm{A}_{1}$ & 0,857 & 0,500 & 0.750 & 0.833 & 0.583 & 0,500 & 0,357 & 0,800 \\
\hline $\begin{array}{l}\mathrm{A}_{2} \\
M d h-1\end{array}$ & 0,143 & 0,500 & 0,250 & 0.167 & $M d h-1$ & 0.500 & 0,643 & 0,200 \\
\hline $\mathrm{A}_{\mathrm{I}}$ & 1,000 & 1.000 & 1.000 & 1,000 & 0.833 & 0.917 & 0,857 & 0.900 \\
\hline $\mathrm{A}_{2}$ & 0,000 & 0,000 & 0,000 & 0,000 & 0.167 & 0,083 & 0,143 & 0.100 \\
\hline \multicolumn{9}{|l|}{ Madh-1 } \\
\hline $\mathrm{A}_{1}$ & 0,643 & 0.250 & 0.500 & 0.833 & 0.417 & 0.667 & 0.500 & 0.800 \\
\hline $\mathrm{A}_{2}$ & 0,357 & 0.750 & 0.500 & 0.167 & 0.583 & 0,333 & 0,500 & 0,200 \\
\hline \multicolumn{9}{|l|}{ Skdh-1 } \\
\hline $\mathrm{A}_{1}$ & 0,143 & 0,000 & 0,500 & 0.500 & 0.417 & 0.750 & 0,357 & 0,000 \\
\hline $\mathrm{A}_{2}$ & 0,714 & 0,750 & 0,250 & 0,167 & 0,500 & 0,000 & 0,571 & 0,600 \\
\hline $\mathrm{A}_{3}$ & 0,000 & 0.000 & 0,000 & 0.000 & 0,000 & 0,000 & 0,000 & 0,400 \\
\hline $\mathrm{A}_{4}$ & 0,143 & 0,250 & 0,250 & 0.333 & 0,083 & 0,250 & 0,071 & 0,000 \\
\hline \multicolumn{9}{|l|}{ Pgi-1 } \\
\hline$A_{I}$ & 0.714 & 0,500 & 1,000 & 0.667 & 0,833 & 1,000 & 0,714 & 1,000 \\
\hline $\mathrm{A}_{2}$ & 0,286 & 0,500 & 0.000 & 0,333 & 0.167 & 0,000 & 0,286 & 0,000 \\
\hline \multicolumn{9}{|l|}{ Pgi-2 } \\
\hline $\mathrm{B}_{1}$ & 0,500 & 0,750 & 0,250 & 0.500 & 0.750 & 0,667 & 0,286 & 0,500 \\
\hline $\begin{array}{l}\mathrm{B}_{2} \\
\mathrm{Me}-\mathrm{I}\end{array}$ & 0,500 & 0.250 & 0,750 & 0,500 & 0.250 & 0,333 & 0.714 & 0.500 \\
\hline$A_{1}$ & 0,643 & 0.750 & 0,500 & 0.333 & 0.750 & 0,833 & 0.714 & 0.600 \\
\hline $\begin{array}{l}\mathrm{A}_{2} \\
\mathrm{Me}-2\end{array}$ & 0.357 & 0.250 & 0.500 & 0.667 & 0.250 & 0.167 & 0.286 & 0.400 \\
\hline $\mathrm{A}_{1}$ & 0.571 & 0,500 & 0.500 & 0.667 & 0.583 & 0,750 & 0.643 & 0.600 \\
\hline $\begin{array}{l}\mathrm{A}_{2} \\
A c p-I\end{array}$ & 0,429 & 0.500 & 0.500 & 0.333 & 0.417 & 0,250 & 0,357 & 0,400 \\
\hline$A_{1}$ & 0.286 & 0,500 & 0.500 & 0,667 & 0.750 & 0,667 & 0,000 & 0,000 \\
\hline $\begin{array}{l}\mathrm{A}_{2} \\
A c p-2\end{array}$ & 0.714 & 0,500 & 0.500 & 0.333 & 0.250 & 0,333 & 1,000 & 1,000 \\
\hline$A_{1}$ & 0.857 & 0.750 & 1,000 & 0.833 & 0.833 & 0,333 & 0.929 & 0.600 \\
\hline $\begin{array}{l}\mathrm{A}_{2} \\
\text { G6pdh-I }\end{array}$ & 0,143 & 0.250 & 0.000 & 0.167 & 0.167 & 0.667 & 0,071 & 0.400 \\
\hline$A_{1}$ & 0,143 & 0.500 & 0.250 & 0.667 & 0.583 & 0,667 & 0,429 & 0,200 \\
\hline $\begin{array}{l}\mathrm{A}_{2} \\
\text { G6pdh-2 }\end{array}$ & 0,857 & 0,500 & 0.750 & 0.333 & 0.417 & 0,333 & 0,571 & 0.800 \\
\hline $\mathrm{B}_{1}$ & 0.500 & 1.000 & 1.000 & 0.667 & 0.750 & 0.750 & 0.500 & 0.400 \\
\hline $\begin{array}{l}\mathrm{B}_{2} \\
\text { Idh-1 }\end{array}$ & 0,143 & 0.000 & 0,000 & 0.333 & 0.250 & 0,250 & 0,500 & 0,600 \\
\hline$A_{1}$ & 0,857 & 1.000 & 1.000 & 0.667 & 0.833 & 0,833 & 0,286 & 0.600 \\
\hline $\mathrm{A}_{2}$ & 0,143 & 0,000 & 0,000 & 0.333 & 0.167 & 0167 & 0,714 & 0,400 \\
\hline
\end{tabular}




\begin{tabular}{|c|c|c|c|c|c|c|c|c|}
\hline \multirow[b]{2}{*}{ Locos } & \multicolumn{8}{|c|}{ Populações } \\
\hline & 9 & 10 & 11 & 12 & 13 & 14 & 15 & 16 \\
\hline \multicolumn{9}{|l|}{ Pgm-1 } \\
\hline$A_{1}$ & 0,357 & 0,500 & 0,500 & 0,500 & 0,417 & 0,583 & 0.500 & 0.500 \\
\hline$A_{2}$ & 0,643 & 0,500 & 0,500 & 0,500 & 0,583 & 0,417 & 0,500 & 0.500 \\
\hline \multicolumn{9}{|c|}{ Populações } \\
\hline Locos & 17 & 18 & 19 & 20 & 21 & 22 & 23 & \\
\hline \multicolumn{9}{|l|}{$4 a t-1$} \\
\hline $\mathrm{A}_{1}$ & 0,750 & 0,682 & 0,833 & 0,524 & 0,278 & 0,500 & 0,500 & \\
\hline $\begin{array}{l}\mathrm{A}_{2} \\
\text { Cap-1 }\end{array}$ & 0,250 & 0,333 & 0,167 & 0,476 & 0.722 & 0,500 & 0,500 & \\
\hline$A_{1}$ & 0,625 & 0,864 & 0,833 & 0,857 & 0.778 & 1,000 & 0,833 & \\
\hline $\mathrm{A}_{2}$ & 0,375 & 0,136 & 0,167 & 0,143 & 0,222 & 0,000 & 0,167 & \\
\hline Mdh-I & & & & & & & & \\
\hline $\mathrm{A}_{1}$ & 0,875 & 0,864 & 0,833 & 0,690 & 0.944 & 1,000 & 1,000 & \\
\hline $\begin{array}{l}\mathrm{A}_{2} \\
\text { Madh-1 }\end{array}$ & 0,125 & 0,136 & 0,167 & 0,310 & 0,056 & 0.000 & 0,000 & \\
\hline$A_{1}$ & 1,000 & 0,818 & 1,000 & 0,929 & 1,000 & 0,600 & 0,667 & \\
\hline $\mathrm{A}_{2}$ & 0,000 & 0,182 & 0,000 & 0,071 & 0,000 & 0,400 & 0,333 & \\
\hline$S k d h-1$ & & & & & & & & \\
\hline$A_{1}$ & 0,250 & 0,455 & 0,500 & 0.595 & 0,389 & 0,100 & 0,167 & \\
\hline $\mathrm{A}_{2}$ & 0,500 & 0,182 & 0,167 & 0,214 & 0,556 & 0,800 & 0,833 & \\
\hline$A_{3}$ & 0,250 & 0,273 & 0,333 & 0,071 & 0,000 & 0,100 & 0,000 & \\
\hline $\begin{array}{l}\mathrm{A}_{4} \\
P g i-1\end{array}$ & 0,000 & 0,091 & 0,000 & 0,119 & 0,056 & 0,000 & 0,000 & \\
\hline$A_{1}$ & 0.500 & 0,773 & 1,000 & 0,619 & 0.389 & 0,600 & 0.000 & \\
\hline $\mathrm{A}_{2}$ & 0,500 & 0,227 & 0,000 & 0,381 & 0,611 & 0,400 & 1,000 & \\
\hline$P g i-2$ & & & & & & & & \\
\hline $\mathrm{B}_{1}$ & 0.625 & 0,500 & 0.833 & 0.833 & 0.778 & 0,900 & 0,500 & \\
\hline $\begin{array}{l}\mathrm{B}_{2} \\
\mathrm{Me}-1\end{array}$ & 0,375 & 0,500 & 0,167 & 0,167 & 0.222 & 0,100 & 0,500 & \\
\hline$A_{1}$ & 0.625 & 0,545 & 0,667 & 0,595 & 0,333 & 0.600 & 0,167 & \\
\hline $\begin{array}{l}\mathrm{A}_{2} \\
\mathrm{Me}-2\end{array}$ & 0,375 & 0,455 & 0.333 & 0,405 & 0.667 & 0,400 & 0,833 & \\
\hline$A_{1}$ & 0,750 & 0,682 & 0,667 & 0,643 & 0.833 & 1,000 & 0,500 & \\
\hline $\begin{array}{l}\mathrm{A}_{2} \\
A c p-1\end{array}$ & 0,250 & 0,318 & 0,333 & 0,357 & 0.167 & 0,000 & 0,500 & \\
\hline$A_{1}$ & 0,250 & 0,182 & 0,000 & 0.452 & 0.111 & 0,000 & 0,000 & \\
\hline $\begin{array}{l}\mathrm{A}_{2} \\
A c p-2\end{array}$ & 0,750 & 0.818 & 1.000 & 0.548 & 0.889 & 1.000 & 1,000 & \\
\hline$A_{1}$ & 0.625 & 0.682 & 0,500 & 0,762 & 0.889 & 1,000 & 1,000 & \\
\hline $\begin{array}{l}\mathrm{A}_{2} \\
\text { G6pdh-1 }\end{array}$ & 0.375 & 0,318 & 0,500 & 0,238 & 0.111 & 0,000 & 0,000 & \\
\hline$A_{1}$ & 0.375 & 0,318 & 0,333 & 0,452 & 0.111 & 0,000 & 0,167 & \\
\hline $\begin{array}{l}\mathrm{A}_{2} \\
\text { G6pdh-2 }\end{array}$ & 0.625 & 0,682 & 0,667 & 0,548 & 0.889 & 1.000 & 0.833 & \\
\hline $\mathrm{B}_{1}$ & 0.375 & 0,545 & 0,667 & 0.929 & 0.333 & 0,700 & 1,000 & \\
\hline $\mathrm{B}_{2}$ & 0,625 & 0,455 & 0,333 & 0,071 & 0.667 & 0.300 & 0,000 & \\
\hline
\end{tabular}




\begin{tabular}{lccccccc}
\hline & \multicolumn{7}{c}{ Populaçoes } \\
\cline { 2 - 8 } Locos & $\mathbf{1 7}$ & $\mathbf{1 8}$ & $\mathbf{1 9}$ & $\mathbf{2 0}$ & $\mathbf{2 1}$ & $\mathbf{2 2}$ & $\mathbf{2 3}$ \\
\hline Idh-l & & & & & & & \\
$\mathrm{A}_{1}$ & 0,875 & 0,955 & 1,000 & 0,952 & 0,778 & 0,900 & 0,833 \\
$\mathrm{~A}_{2}$ & 0,125 & 0,045 & 0,000 & 0,048 & 0,222 & 0,100 & 0,167 \\
$P g \operatorname{m}-1$ & & & & & & & \\
$\mathrm{~A}_{1}$ & 0,625 & 0,455 & 0,667 & 0,619 & 0,722 & 0,500 & 0.500 \\
$\mathrm{~A}_{2}$ & 0,375 & 0,545 & 0.333 & 0,381 & 0.278 & 0.500 & 0.500 \\
\hline
\end{tabular}

$\mathrm{N}=$ número de clones analisados por população

Hamrick (1985) relata que as medidas mais comumente utilizadas para estimar os níveis de variabilidade intrapopulacional, quando se trabalha com isoenzimas, são a porcentagem de locos polimórficos, o número de alelos por loco e a heterozigosidade média.

A presença da variabilidade genética dentro das populações tem a função de propiciar aos indivíduos melhor adaptação bem como flexibilidade para expressar fenótipos distintos em situações temporárias de estresses, garantindo a sobrevivência dos mesmos (Marcon, 1988), possivelmente essa variabilidade genética presente nas etnovariedades estudadas permitem sua adaptação nos diversos ambientes em que são encontradas.

Autores como Weir (1990) e Nei (1973) consideram a freqüência de heterozigotos um importante indicador de diversidade genética, pois cada heterozigoto carrega alelos diferentes representando melhor a variação existente tanto em populações de espécies autógamas como alógamas. A diversidade genética é medida em nível de população ou de unidade de amostra e depois comparada entre populações (Alfenas, et al., 1991). 
Brown (1978) sugere o emprego de marcadores bioquímicos como as isoenzimas para estudos de diversidade genética em populações naturais a partir de amostragens genéticas. Estes marcadores apresentam características de neutralidade, codominância, não interferência do meio ambiente nas avaliações, etc. Por esses motivos, o marcador foi utilizado para estimar a diversidade genética nas populações não naturais constituídas pelas roças de etnovariedades de mandioca.

Segundo Hershey (1992), a variação isoenzimática observada em diferentes culturas tem permitido identificação de centros de domesticação e padrões geográficos de diversidade genética.

Os resultados obtidos em relação às freqüências alélicas e níveis de diversidade mostram existência de diferenças significativas entre as roças estudadas, bem como entre as diferentes regiões quando comparadas, indicando divergência entre as mesmas.

Observa-se que nas roças originadas da região Xingu (roças 21, 22 e 23) apresentaram maior número de alelos fixados, possivelmente, por estar havendo seleção em favor de alguns alelos; ação de deriva genética, em decorrência de ser uma população pequena; e ou pequeno intercambio de material, já que as trocas de etnovariedades ficam em nível de poucas tribos indígenas.

As frequiências gênicas estão relacionadas com fatores geográficos, ambientais, históricos, sistema de cruzamento, etc. Porém, as freqüências não permitem responder questões da maneira como a variabilidade é mantida dentro da população, apenas fornece informações relacionadas com as forças de atuação. Estudos experimentais que 
envolvam a variação genética em populações necessitam serem realizados com maior frequência.

A maioria das roças (aproximadamente 60\%) não apresentou o alelo $A_{3}$ do loco $S k d h-1$, com exceção das roças 2,4,8, 16,17,18,19,20 e 22. Observa-se também na Tabela 5 que a Região do médio Amazonas foi a única que apresentou esse alelo em todas as suas roças $(17,18,19$ e 20), com valores de freqüência que variaram desde $7,1 \%$ a $33,3 \%$.

As roças coletadas na Região Amazônica possuem todos os alelos presentes na demais regiões (Tabela 5). Os resultados mostram diferenças entre as diferentes regiões amostradas, indicando divergências entre elas. A divergência observada entre as regiões deve estar relacionada como o manejo das roças, migração de material genético e introdução de cultivares realçada pelo homem (troca de etnovariedades). Segundo Cury (1993), a migração é uma das causas responsáveis pelo fluxo gênico entre diferentes roças de mandioca e regiões geográficas, pois a dispersão natural de sementes e de gametas via pólen é muito limitada.

As técnicas agrícolas utilizadas no manejo da agricultura tradicional não diminuem as pressões de seleção natural (Cury, 1993). Desta forma, as freqüências alélicas observadas na Tabela 5, evidenciam que os alelos não fixados nas roças estão sujeitos a sofrerem pressões de seleção e alterar sua frequência, já que é esperado que os locos não se encontrem em Equilíbrio de Hardy-Weinberg. Dentro do modelo de dinâmica evolutiva da mandioca, proposto por Cury (1993), esse seria um dos processos responsáveis pela manutenção e amplificação da variabilidade genética. 


\subsubsection{Variabilidade Genética em nível de roça.}

A variabilidade genética observada nas populações de $M$. esculenta, para os 15 locos estudados, em termos de número médio de alelos, porcentagem de locos polimórficos, e heterozigosidade média observada $\left(\mathrm{H}_{\mathrm{o}}\right)$ é apresentada na Tabela 6 .

O número médio de alelos por loco apresentou variação de acordo com a população, variando de 1,5 a 2,1. Algumas roças mostraram o mesmo valor de alelos por loco, como as roças $1,11,22$ e $23(1,7$ alelos por loco). As roças 3, 10, e 19 apresentaram 1,8 alelos por loco. As roças 5, 7, 14, e 16 apresentam número médio de alelos por loco igual a 1,9. As populações pertencentes às roças $9,12,15,17$ e 21 apresentam, em média, 2,0 alelos por loco. As roças 2, 4, 8, 13, 15, 18 e 20 têm médias com valores iguais a 2,1 alelos por loco. Somente a roça 6 mostrou valor de 1,5 alelo/loco. Como pode ser observado, as roças de mesma região não apresentaram mesmo número de alelos por loco, formando grupos aleatórios entre roças de diferentes regiões. Esse fato, possivelmente, se deve ao efeito fundador das roças ou diferentes níveis de pressão seletiva.

A variabilidade genética medida pelo número médio de alelos por loco, nas roças estudadas, manteve-se na média 1,9 alelos por loco, considerando os onze sistemas enzimáticos analisados, embora não se possa afirmar com segurança que esse número de alelos por loco observado seja baixo, uma vez que na literatura não existem dados com mandioca, para comparação dos resultados. Os valores encontrados nos indivíduos podem 
Tabela 6. Variabilidade genética observada em vinte e três roças (populações) de M. esculenta Crantz, para os 15 locos isoenzimáticos analisados.

\begin{tabular}{|c|c|c|c|c|c|}
\hline ORIGEM & POPULAÇĀO & $\begin{array}{c}\text { TAMANHO } \\
\text { DA } \\
\text { AMOSTRA }\end{array}$ & $\begin{array}{c}\text { NÚMERO } \\
\text { MÉDIO DE } \\
\text { ALELOS POR } \\
\text { LOCO }\end{array}$ & $\begin{array}{c}\text { PORCENT AGEM DE } \\
\text { LOCOS } \\
\text { POLIMÓRFICOS } \\
(0.95)^{\star}\end{array}$ & $\begin{array}{c}\text { HETEROZIGO- } \\
\text { SIDADE MÉDIA } \\
\text { OBSERVADA } \\
\left(\mathrm{H}_{\mathrm{o}}\right)\end{array}$ \\
\hline R. NEGRO & ROÇA 01 & 2,0 & $\begin{array}{c}1,7 \\
(0,1)\end{array}$ & 66,7 & $\begin{array}{c}0,400 \\
(0,111)\end{array}$ \\
\hline R. NEGRO & ROÇA 02 & 6,0 & $\begin{array}{c}2,1 \\
(0,2)\end{array}$ & 93,3 & $\begin{array}{c}0,300 \\
(0,067)\end{array}$ \\
\hline R. NEGRO & ROÇA 03 & 3,0 & $\begin{array}{c}1,8 \\
(0,1)\end{array}$ & 80,0 & $\begin{array}{c}0,467 \\
(0,091)\end{array}$ \\
\hline R. NEGRO & ROÇA 04 & 14,0 & $\begin{array}{c}2,1 \\
(0,1)\end{array}$ & 100,0 & $\begin{array}{c}0,286 \\
(0,045)\end{array}$ \\
\hline R. BRANCO & ROÇA 05 & 4,0 & $\begin{array}{c}1,9 \\
(0,1)\end{array}$ & 86,7 & $\begin{array}{c}0,333 \\
(0,072)\end{array}$ \\
\hline R. BRANCO & ROÇA 06 & 2,0 & $\begin{array}{c}1,5 \\
(0,1)\end{array}$ & 53,3 & $\begin{array}{c}0,400 \\
(0,121)\end{array}$ \\
\hline R. BRANCO & ROÇA 07 & 3,0 & $\begin{array}{c}1,9 \\
(0,1)\end{array}$ & 86,7 & $\begin{array}{c}0,333 \\
(0,080)\end{array}$ \\
\hline M. GROSSO & ROÇA 08 & 11,0 & $\begin{array}{c}2,1 \\
(0,1)\end{array}$ & 100,0 & $\begin{array}{c}0,382 \\
(0,078)\end{array}$ \\
\hline M. GROSSO & ROÇA 09 & 7,0 & $\begin{array}{c}2,0 \\
(0,1)\end{array}$ & 93,3 & $\begin{array}{c}0,286 \\
(0,079)\end{array}$ \\
\hline M. GROSSO & ROÇA 10 & 2,0 & $\begin{array}{c}1,8 \\
(0,1)\end{array}$ & 80,0 & $\begin{array}{c}0,467 \\
(0,103)\end{array}$ \\
\hline M. GROSSO & ROÇA 11 & 2,0 & $\begin{array}{c}1,7 \\
(0,2)\end{array}$ & 66,7 & $\begin{array}{c}0,400 \\
(0,111)\end{array}$ \\
\hline R. SOLIMÕES & ROÇA 12 & 3,0 & $\begin{array}{c}2,0 \\
(0,1)\end{array}$ & 93,3 & $\begin{array}{c}0,422 \\
(0,089)\end{array}$ \\
\hline R. SOLIMÕES & ROÇA 13 & 6,0 & $\begin{array}{c}2,1 \\
(0,1)\end{array}$ & 100.0 & $\begin{array}{c}0,378 \\
(0,080)\end{array}$ \\
\hline R. SOLIMÕES & ROÇA 14 & 6,0 & $\begin{array}{c}1,9 \\
(0,1)\end{array}$ & 93,3 & $\begin{array}{c}0,300 \\
(0,052)\end{array}$ \\
\hline SÃO PAULO & ROÇA 15 & 7,0 & $\begin{array}{c}2,0 \\
(0,1)\end{array}$ & 93,3 & $\begin{array}{c}0,448 \\
(0,081)\end{array}$ \\
\hline SÃO PAULO & ROÇA 16 & 5,0 & $\begin{array}{c}1,9 \\
(0,1)\end{array}$ & 86,7 & $\begin{array}{c}0,373 \\
(0,087)\end{array}$ \\
\hline PARÁ & ROÇA 17 & 4,0 & $\begin{array}{c}2,0 \\
(0,1)\end{array}$ & 93,3 & $\begin{array}{c}0,350 \\
(0,068)\end{array}$ \\
\hline PARÁ & ROÇA 18 & 11,0 & $\begin{array}{c}2,1 \\
(0,1)\end{array}$ & 93,3 & $\begin{array}{c}0,345 \\
(0,072)\end{array}$ \\
\hline PARÁ & ROÇA 19 & 3,0 & $\begin{array}{c}1,8 \\
(0,1)\end{array}$ & 73,3 & $\begin{array}{c}0,333 \\
(0,073)\end{array}$ \\
\hline PARÁ & ROÇA 20 & 21,0 & $\begin{array}{c}2,1 \\
(0,1)\end{array}$ & 93,3 & $\begin{array}{c}0,349 \\
(0,065)\end{array}$ \\
\hline XINGU & ROÇA 21 & 9,0 & $\begin{array}{c}2,0 \\
(0,1)\end{array}$ & 93,3 & $\begin{array}{c}0,296 \\
(0,053)\end{array}$ \\
\hline XINGU & ROÇA 22 & 5,0 & $\begin{array}{c}1,7 \\
(0,2)\end{array}$ & 60,0 & $\begin{array}{c}0,307 \\
(0,101)\end{array}$ \\
\hline XINGU & ROÇA 23 & 3,0 & $\begin{array}{c}1,7 \\
(0,1) \\
\end{array}$ & 66,7 & $\begin{array}{c}0,422 \\
(0,105) \\
\end{array}$ \\
\hline
\end{tabular}

* Um loco é considerado polimórfico se a freqüência do alelo mais comum não exceder a 0.95 .

** Os números entre parênteses referem-se aos desvios padrões. 
estar sendo influenciado pelo pequeno tamanho da amostra, pois existem roças em que foram amostradas apenas duas etnovariedades.

A porcentagem de locos polimórficos encontrada nas populações variou de 53,3 a 100,0\%, utilizando-se o critério de que um loco foi considerado polimórfico quando a freqüência do alelo mais comum não ultrapassou 0,95 . Os altos valores obtidos podem ter sido em função de a análise ter sido realizada, exclusivamente, com locos polimórficos.

De acordo com esse critério, a roça 6 (Rio Branco) foi a que mostrou menor polimorfismo $(53,3 \%)$, provavelmente por estar representada apenas por dois indivíduos. A roça 22 (Xingu) também mostrou polimorfismo ao redor de 60,0\%. As demais apresentaram valores de 66,7 a $100,0 \%$. Contudo, os menores valores observados são considerados altos quando comparados aos valores obtidos para plantas cultivadas (Hamrick \& Godt, 1984). Além disso, nas roças 4, 8, e 13 (Rio Negro, Mato Grosso e Rio Solimões, respectivamente) foram obtidos valores de $100,0 \%$ de locos polimórficos.

Os valores de heterozigosidade observada ( $\mathrm{Ho})$ para as 23 roças amostradas podem ser visualizados na Tabela 6 .

A heterozigosidade observada estima a probabilidade de que dois alelos tomados ao acaso na população sejam diferentes. A medida está sujeita a limitações como: tamanho pequeno da amostra que pode desviar as frequências genotípicas das proporções do Equilíbrio de Hardy-Weinberg, em função de erros de amostragem; efeito de seleção natural forte e endogamia (Torggler et al., 1995). O valor da heterozigosidade observada para as roças originadas do Rio Negro ser menor que o observado para as 
roças originadas do Estado de São Paulo, possivelmente se deve ao fato que, desse último foi analisado número muito menor de roças (Tabela 6).

Hamrick \& Godt (1989), em uma revisão que reuniu dados de literatura que apresentassem estudos relativos a diferentes espécies de plantas avaliadas por marcadores isoenzimáticos, mostraram que, na média, as espécies apresentaram valores de heterozigosidade esperada ao redor de 0,149 e em nível de população, ao redor de 0,113. Diante desse fato, os valores de 0,286 a 0,467 (Tabela 6), podem ser considerados elevados.

A análise de locos isoenzimáticos em estudos de populações tem permitido aumentar o nível de conhecimento da estrutura genética de populações de plantas. Os padrões de distribuição de variação genética dentro e entre populações estão mais claros e evidentes nos dias de hoje. Uma outra vantagem cada vez mais promissora e real é a utilização de variação aloenzimática em conjunto com outros marcadores moleculares, permitindo obter dados que expliquem a influência do sistema de cruzamento em plantas, dispersão de sementes e sobrevivência diferencial na estrutura genética de populações de plantas (Hamrick \& Godt, 1989).

Diante dos resultados obtidos é possível inferir que o agricultor mantém e/ou amplifica a variabilidade genética em suas roças de agricultura tradicional autóctone. A diversidade é mantida com enfoque especial dado ao perfil de interesse do agricultor em relação ao material genético que deseja preservar e conservar. É interessante ressaltar que a maioria dos agricultores está preocupada em manter certo número de etnovariedades como um pequeno banco de germoplasma in situ, como foi observado por 
Sambatti (1998) em roças alteradas e não alteradas do litoral do Estado de São Paulo (Ubatuba).

Por outro lado, discordâncias entre avaliações utilizando características morfológicas e isoenzimáticas da diversidade ocorrem em diversas espécies (Jain, 1992). Por exemplo, Millar (1986), revisando a questão, relatou que em muitas coníferas a variação para caracteres morfológicos e fisiológicos é bem maior que para caracteres isoenzimáticos.

Faraldo (1994) analisou sete populações do litoral sul do Estado de São Paulo e concluiu que estes resultados indicam a existência de diferenças genéticas entre as etnovariedades de uma mesma roça, entre roças e entre as regiões geográficas.

Lefèvre \& Charrier (1993b) apresentam valores de heterozigosidade para 365 acessos de M. esculenta e 109 acessos da espécie silvestre M. glaziovil, onde as médias foram de 0,225 e 0,252, respectivamente. $\mathrm{O}$ valor médio da variabilidade genética encontrado nas populações de mandioca do Vale do Ribeira (litoral sul do Estado de São Paulo) foi de 0,242 , portanto superior à média de variabilidade estimada pelos autores.

A agricultura autóctone, cujas bases técnicas remontam ao período pré-colonial, guarda em suas populações grande diversidade intraespecífica das espécies cultivadas. A mandioca é a principal espécie cultivada neste tipo de agricultura. Alguns autores como Chernela (1987) relacionam a diversidade intra-especifica com a diversidade cultural do local, embora sejam raros os trabalhos que relatam as causas da diversidade intra-específica da mandioca. 
Brush (1992) e Salick (1992; 1995; 1997) enfatizaram a importância de conservar a diversidade local e manter as práticas agrícolas tradicionais paralelas com as práticas agrícolas modernas, que muito contribuem para o aumento e manutenção da variabilidade, evitando dessa forma a erosão genética.

Rogers $(1965 ; 1973)$ afirma que nas áreas onde o material cultivado ( $M$. esculenta) é mantido, são encontradas numerosas espécies silvestres as quais podem se cruzar com os cultivares presentes nesses locais e originar raças colonizadoras, chegando a conclusão que o processo de domesticação da mandioca ocorreu simultaneamente em várias regiões.

A grande variabilidade fenotípica observada em mandioca deve estar relacionada com o caráter perene da espécie, aos modos de reprodução vegetativa e sexual (alogamia), e da dispersão e armazenamento das sementes no solo (banco de sementes), que permitem a introdução de novos recombinantes no conjunto original de variabilidade da espécie.

\subsubsection{Variabilidade Genética em nível de Regiões geográficas.}

A variabilidade genética obtida a partir das análises feitas considerando-se regiões, ou seja, agrupando-se roças de acordo com a região de coleta, permitiu evidenciar 2,2 alelos por loco na média. Quando utilizou-se análises levando em consideração a roça, esse número médio de alelo por loco ficou ao redor de 1,9 refletindo a suposição de que o número de indivíduos amostrados influencia nos resultados (Tabela 7). 
Tabela 7. Variabilidade genética observada nas sete regiões de $M$. esculenta Crantz, para os 15 locos isoenzimáticos analisados.

\begin{tabular}{|c|c|c|c|c|}
\hline POPULAÇÃO & $\begin{array}{l}\text { TAMANHO DA } \\
\text { AMOSTRA }\end{array}$ & $\begin{array}{l}\text { NÚMERO MÉDIO } \\
\text { DE ALELOS POR } \\
\text { LOCO }\end{array}$ & $\begin{array}{c}\text { PORCENTAGEM } \\
\text { DE LOCOS } \\
\text { POLIMÓRFICOS } \\
(0.95) \\
\star\end{array}$ & $\begin{array}{c}\text { HETEROZI- } \\
\text { GOSIDADE MĖDIA } \\
\text { OBSERVADA }\left(\mathrm{H}_{0}\right)\end{array}$ \\
\hline 1. Rio Negro & 25,0 & $\begin{array}{c}2,2 \\
(0,1)\end{array}$ & 93,8 & $\begin{array}{c}0,300 \\
(0,054)\end{array}$ \\
\hline 2. Rio Branco & 9,0 & $\begin{array}{c}2,1 \\
(0,1)\end{array}$ & 100,0 & $\begin{array}{c}0,326 \\
(0,073)\end{array}$ \\
\hline 3. Mato Grosso & 220 & $\begin{array}{c}2.2 \\
(0,1)\end{array}$ & 100,0 & $\begin{array}{c}0,338 \\
(0,074)\end{array}$ \\
\hline 4. Rio Solimões & 14,0 & $\begin{array}{c}2.1 \\
(0,1)\end{array}$ & 100,0 & $\begin{array}{c}0,326 \\
(0.058)\end{array}$ \\
\hline 5. São Paulo & 13,0 & $\begin{array}{c}2.2 \\
(0,1)\end{array}$ & 100,0 & $\begin{array}{c}0,394 \\
(0,080)\end{array}$ \\
\hline 6. Pará & 42,0 & $\begin{array}{c}2.3 \\
(0,2)\end{array}$ & 93,8 & $\begin{array}{c}0,335 \\
(0,059)\end{array}$ \\
\hline 7. Xingu & 17,0 & $\begin{array}{c}2,2 \\
(0,1)\end{array}$ & 93,8 & $\begin{array}{c}0,301 \\
(0,061)\end{array}$ \\
\hline
\end{tabular}

* Um loco é considerado polimórfico se a freqüência do alelo mais comum não exceder a 0.95.

*** Os números entre parênteses referem-se aos desvios padrões.

O mesmo foi observado em relação à porcentagem de locos polimórficos onde foram obtidos apenas dois valores diferentes, sendo o menor ficou em $93,8 \%$ e o maior $100 \%$. As populações constituídas pelas roças do Rio Negro, Estado do Pará e Parque Indígena do Xingu mostraram valores de 93,8\% de locos polimórficos; as demais (Rio Branco, Mato Grosso, Rio Solimões e litoral sul do Estado de São Paulo) apresentaram valores de $100,0 \%$ de locos polimórficos.

O resultado mais curioso ficou com as amostras pertencentes à região do Rio Branco, onde na análise que considerou apenas a roça/comunidade, a roça n. 6 mostrou-se menos polimórfica $(53,3 \%)$. No 
caso das etnovariedades pertencentes à região do Rio Branco, cuja amostra totalizou 9 indivíduos diferentes, a variabilidade genética foi alta permitindo inferir ser os indivíduos coletados representativos da roça de coleta.

$\mathrm{O}$ número médio de alelos por loco $(\mathrm{A})$ praticamente não apresentou valores discrepantes, pois variaram de 2,1 a 2,3 alelos por loco. Diferenças grandes de valores foram observados quando comparados às análises feitas por roça e não por região. Esse valor de 2,1 alelos por loco, em média, representa um valor alto quando comparado ao valor de 1,79 alelos/loco encontrado por Hamrick \& Godt (1989) no grupo das dicotiledôneas. Segundo Nei (1978), a estatística do número médio de alelos por loco (A) é muito influenciada pelo tamanho da amostragem genética (número de loco) na coleta, o que pode estar acontecendo no presente trabalho.

A porcentagem de locos polimórficos $(\mathrm{P})$ observada pode ser considerada alta $(97,34 \%$ em média) contra $44,8 \%$ para as dicotiledôneas. Se fôr considerado o modo de reprodução da espécie (sexual ou assexual), esse valor diminui para 43,8\% e 1,69 alelos por loco, mantendo o valor encontrado no material genético presente nas roças de etnovariedades de mandioca bem mais elevado, com diferença significativa. Mesmo levando em conta o valor de $\mathrm{P}$ em relação à distribuição da variabilidade em regiões tropicais, que é de 49,2 e 1,81 alelos por loco, os valores obtidos para essas duas estimativas de variabilidade genética continuam sendo maior nas roças de agricultura tradicional analisadas. 
Hamrick \& Godt (1989) encontraram 50\% de locos polimórficos para as espécies vegetais. Pode-se considerar que as regiões de coleta de etnovariedades de mandioca apresentam alto polimorfismo (97,34\%, na média). Mesmo considerando-se o valor obtido em nível de roça $(84,5 \%)$, o polimorfismo ainda é maior que a média encontrada para as espécies vegetais.

A heterozigosidade média observada nas regiões geográficas variou de 0,300 a 0,394 com valor médio de 0,331 . Os valores de Ho mostraram-se pouco contrastantes entre si, para análises feitas por região de coleta, mostrando diferenças mais significativas em nível de roça por região (Tabela 6 e 7).

Freitas (1997, comunicação pessoal), relatou que os índios das tribos Waurá e Yawalapiti no Parque Indígena do Xingu, selecionam as etnovariedades germinadas a partir de sementes. Estas são experimentadas, avaliadas sendo posteriormente multiplicadas e incorporadas ao conjunto de etnovariedade local com o nome de "veio do céu". Segundo Boster (1985), indivíduos provenientes de sementes são denominados de "yagkujî" (flor) ou "tsapaínu" (broto), evidenciando as partes envolvidas com a reprodução da planta na nomenclatura. Sambatti (1998) e Boster (1985) também chamam a atenção para esse tipo de prática cultural, onde os agricultores dão nomes ao material genético em função de alguma característica particular do indivíduo.

O agricultor observa nas roças indivíduos diferentes do conjunto de etnovariedades de sua roça. A raiz é pivotante, ou seja, a presença de uma única raiz e não o desenvolvimento de várias raizes 
característica de germinação a partir de gemas do caule, fenômeno comum em material de propagação vagetativa. Este fato mostra evidências da possibilidade de formação de banco de sementes (Martins, 1994). As sementes presentes no solo de roças germinam somente quando as condições se mostram favoráveis, permanacendo dormentes por períodos indeterminados. Assim, o banco de semente possui papel de destaque na compreensão do processo de dinâmica evolutiva da mandioca.

Amorozo (1996), também, relata sobre a existência de material de mandioca proveniente de sementes nas roças do Mato Grosso, especialmente, nas pertencentes a Santo Antônio do Lèverger. Existem roças desse local que são formadas praticamente por material originado de sementes.

Os trabalhos citados caracterizam a amplificação da variabilidade genética realizada de forma inconsciente pelo produtor.

\subsection{Distribuição da variabilidade genética.}

A caracterização da distribuição da variabilidade genética entre e dentro de roças e entre e dentro de regiões foi realizada considerando a abordagem: GST de Nei (1973).

A distribuição da diversidade genética entre e dentro das populações depende do fluxo gênico e dos mecanismos de reprodução nas plantas. 
Na Tabela 8, observam-se valores $\mathrm{G}_{\mathrm{ST}}$ referentes a distribuição da variação genética em nível de roças, sendo constatado maior variabilidade dentro das roças. Resultado semelhante ao encontrado nas análises feitas por região. O valor de $G_{S T}$ foi de 0,165 (16,46\%), ou seja, 16,46\% da variabilidade genética se encontra entre roças e $83,54 \%($ Dis $=0,835)$ dentro das roças. Resultados semelhantes foram encontrados por Cury (1998), trabalhando com características morfológicas e Sambatti (1998) com isoenzimas.

Dessa forma, a estimativa $G_{S T}$ apresentou valor de 0,088 indicando que a variação genética entre as diferentes regiões geográficas foi de $8,80 \%$, ou seja, $8,80 \%$ da variabilidade genética total está contida entre populações (regiões) e $91,20 \%$ dentro das regiões (Dis $=0,912$ ou $91,20 \%$ ) (Tabela 9).

A maior concentração da variabilidade genética dentro de roças, dentro das diferentes regiões, possivelmente está relacionado com a ocorrência de fluxo gênico entre as populações, como consequência da troca ou introdução de material (etnovariedades) nas populações. O resultado coincide com a distribuição da variabilidade genética em populações naturais de plantas alógamas.

Os resultados observados, na Tabela 8 e 9 , indicam que a maior parte da variabilidade genética está concentrada dentro das populações de mandioca. $\mathrm{Na}$ literatura existente sobre estimativa da variabilidade genética em populações naturais de outras espécies, são utilizadas outras metodologias, como a Estatística F de Wright (1965), não permitindo comparação com estes resultados. 
Tabela 8: Variabilidade genética observada nas 23 roças de etnovariedades de mandioca ( $M$. esculetna) para os 15 locos isoenzimáticos analisados.

\begin{tabular}{|c|c|c|c|c|}
\hline $\begin{array}{c}\text { Loco } \\
\text { enzimátic } \\
\end{array}$ & $\mathbf{H}_{\mathrm{T}}$ & $\mathbf{H}_{\mathbf{s}}$ & $\mathrm{G}_{\text {ST }}$ & Dentro (Dis) \\
\hline$A A T-1$ & 0,496 & 0,449 & 0,095 & 0,905 \\
\hline CAP-I & 0,430 & 0.335 & 0,222 & 0.778 \\
\hline$M D H-1$ & 0,204 & 0,184 & 0,097 & 0,903 \\
\hline$M A D H-I$ & 0,358 & 0.304 & 0.151 & 0.849 \\
\hline$S K D H-1$ & 0,671 & 0,534 & 0,205 & 0,795 \\
\hline$P G I-1$ & 0,461 & 0,374 & 0,187 & 0,813 \\
\hline$P G I-2$ & 0,481 & 0,401 & 0,167 & 0,833 \\
\hline$M E 1-1$ & 0.484 & 0.451 & 0,067 & 0,933 \\
\hline$M E 1-2$ & 0,463 & 0,431 & 0,069 & 0,931 \\
\hline$A C P-1$ & 0,433 & 0.307 & 0,291 & 0,709 \\
\hline$A C P-2$ & 0,486 & 0,415 & 0.303 & 0.697 \\
\hline G6PDH-I & 0,407 & 0.327 & 0.146 & 0.854 \\
\hline G6PDH-2 & 0,267 & 0.212 & 0,196 & 0.804 \\
\hline$I D H-I$ & 0.495 & 0,461 & 0,204 & 0,796 \\
\hline$P G M-1$ & 0.465 & 0.324 & 0.069 & 0.931 \\
\hline Média & 0.440 & 0,367 & 0.165 & 0.835 \\
\hline Desvio & 0.028 & 0.025 & 0.005 & 0.005 \\
\hline
\end{tabular}

$\mathrm{H}_{\mathrm{S}}=$ diversidade média em um loco

$\mathrm{H}_{\mathrm{T}}=$ diversidade genética total

$\mathrm{G}_{\mathrm{ST}}=$ proporção de diversidade entre populações

$\mathrm{D}_{\mathrm{IS}}=$ proporção de diversidade dentro de populações 
Tabela 9: Variabilidade genética observada nas 7 regiões de coleta das emovariedades de mandioca (M. esculetna) para os 15 locos isoenzimáticos analisados.

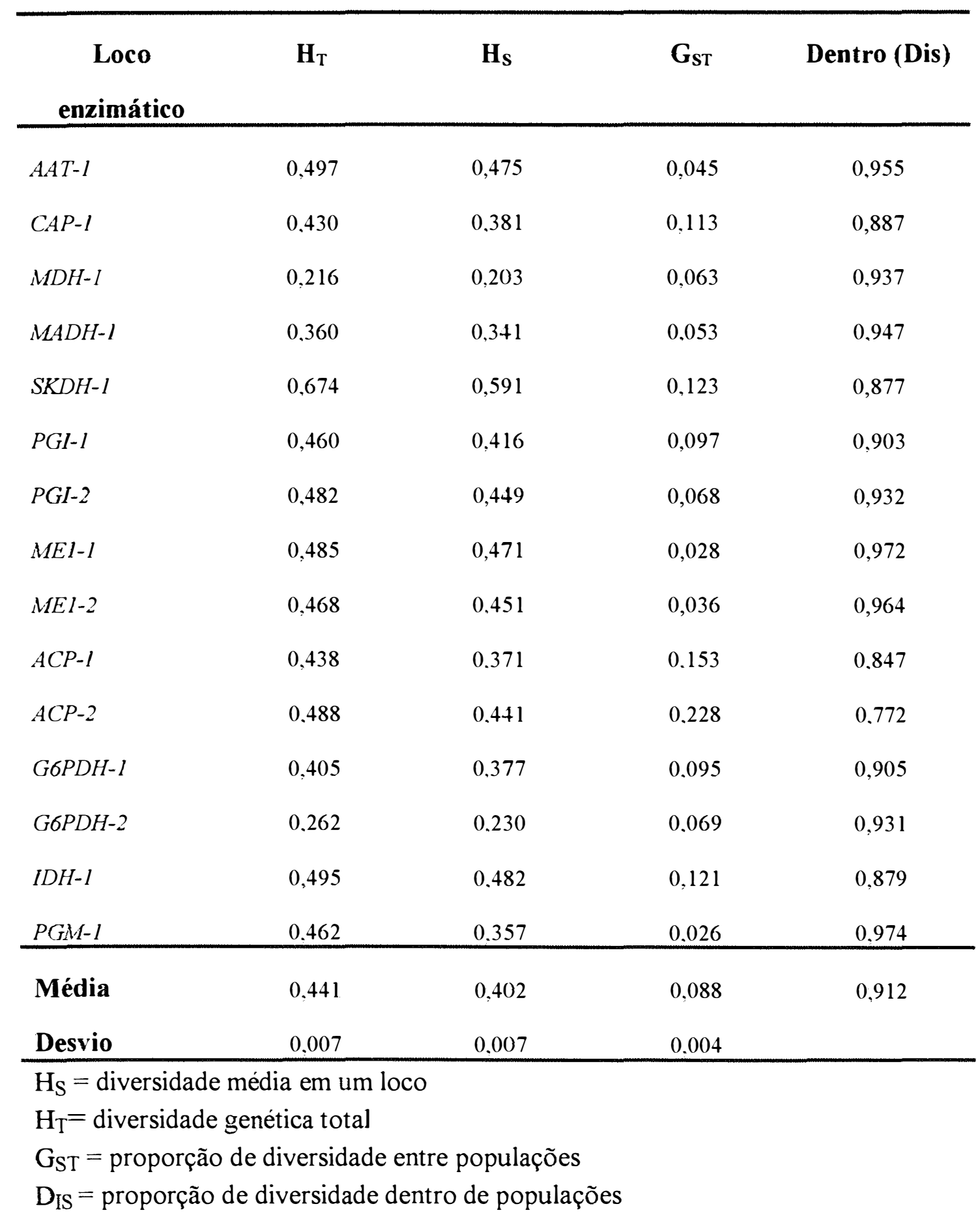


Hamrick (1989) afirma que o fluxo gênico intenso entre as populações tende a homogenizar a variabilidade genética. $\mathrm{O}$ autor, certamente, refere-se ao fluxo gênico de pólen em populações naturais, contudo, certamente, o mesmo efeito esta sendo realizado com as população aqui analisadas através do intercâmbio de material onde as roças foram coletadas.

A concentração da variabilidade genética dentro das roças e regiões (populações não naturais) coincide com a distribuição da variabilidade genética em populações alógamas.

\subsection{Taxonomia "folk"}

A taxonomia "folk" é utilizada para o entendimento da dinâmica biológica da cultura. Os relatos feitos pelos agricultores, acumulados ao longo da história, mostram que a seleção, manutenção ou troca de material, execultados pelo pequenos agricultores é feita em nível de variedade e não de população.

As etnovariedades DG - 94 e DG - 95, originadas da Região do Mato Grosso, denominadas "Mata Rato" apresentaram os mesmos fenótipos em todos os sistemas enzimáticos utilizados, indicando tratar-se do mesmo material.

As etnovariedades DG - 126, 127 e 132 apresentam o mesmo nome (Aipim roxo - Tabela 1), originadas da Região do litoral Sul do Estado de São Paulo, contudo somente $50 \%$ de padrões fenotípicos são idênticos para as três primeiras. Peroni (1998), também, detectou variação dentro de 
clones, ou seja, o clone indentificado com o mesmo nome pelo agricultor e com igual características morfológicas, apresentou diferenças genéticas em nível isoenzimático; o mesmo genótipo apresentando variações, que o autor denominou de variação intraclonal.

A DG - 134, originada de Ilha Comprida-SP, mostrou padrão fenotípico idêntico ao padrão da DG - 132, evidenciando troca de material entre as roças de diferentes locais.

Os resultados apresentados, no presente trabalho, mostram que há correspondência entre a classificação local da diversidade (taxonomia folk) e a classificação fenotípica realizada através dos padrões isoenzimáticos, pois poucas etnovariedades denominadas com o mesmo nome apresentaram diferentes padrões isoenzimáticos. Corroborando o exposto por Sambatti (1998) que observou certa coerência entre o sistema taxonômico local e a classificação fenotípica obtida através de isoenzimas.

Nos estudos que envolvem variedades tradicionais ou variedades "folk", os pesquisadores enfatizam suas observações em nível de indivíduo e não de grupo. As seleções dentro das roças são feitas baseandose em seleção inconsciente individual de acordo com o interesse local, pois muitas vezes trata-se de agricultura sustentável (Gaifami \& Cordeiro, 1992). Essa prática é tão real e marcante entre os agricultores que eles selecionam material genético que apresenta características contrastantes para que não exista dificuldades na separação e manutenção da(s) etnovariedade(s) que lhes interessam.

Quiros et al. (1990) afirmam que a taxonomia "folk" auxilia na determinação de práticas de cultivo para os sistemas de dinâmica evolutiva 
dos campos de batatas dos Andes, onde novas variedades e talvez novas espécies são geradas a partir de hibridização ou introgressão de espécies selvagens. Os mesmos autores, também, enfatizam o uso de marcadores bioquímicos como as isoenzimas, como ferramentas bastante eficientes para estudos de diversidade.

Quiros et al. (1990) levantaram algumas questões em relação à grande diversidade intra-específica observada em plantas cultivadas, e o motivo dessa diversidade concentra-se em certas áreas. Os autores acreditam que estas questões estão diretamente envolvidas com a falta de conhecimento da base genética da cultura, bem como de melhor compreensão e entendimento na maneira pela qual os agricultores percebem e selecionam as culturas mantendo e amplificando a diversidade local.

Em relação à classificação local das etnovariedades, existem evidências de subestimação da variabilidade genética dentro da roça da agricultura tradicional (Peroni, 1998).

Freitas (1997 - comunicação pessoal) ressalta que entre os índios das tribos Waurá e Yawalapiti no Parque Indígena do Xingu, as variedades de mandioca germinadas a partir de sementes são experimentadas, avaliadas sendo posteriormente multiplicadas e incorporadas ao conjunto de cultivares com a denominação "que veio do céu".

O trabalho de Boster (1985) sobre taxonomia de M. esculenta Crantz em Aguaruna, mostrou que o método de taxonomia folk de variabilidade intra-especifica pode ser útil na compreensão da manutenção da diversidade local. 


\subsection{Análise da Variabilidade Genética - Através de Agrupamento.}

$\mathrm{Na}$ Figura 13, observa-se que as roças originadas do Estado do Pará, Estado do Mato Grosso e a Reserva Indígena do Xingu formaram subgrupos individuais, caracterizando que entre elas existe certa similaridade genética. Contudo, se elas ficassem isoladas essa pequena separação se tornaria em nível de região.

Portanto, a distribuição da variabilidade genética de mandioca nas áreas amostradas está relacionadas às regiões geográficas conforme observado em outras espécies, por exemplo Marcon (1988) em espécies do gênero Stylosanthes.

É verdade que não existe grande diversidade entre roças das diferentes regiões geográficas, pois a distância genética entre elas não foi grande, máximo de $25 \%$, contudo pode se tornar maior em decorrência do fluxo gênico interno. Isso é verdade se for cessado o intercâmbio de material, pois existe uma tendência de plantar maior área com variedade melhorada.

A Análise de agrupamento em nível de região geográfica permitiu a caracterização de 3 grupos distintos quanto à distância de comportamento para o conjunto das variedades de $M$. esculenta do presente estudo (Figura 14). O primeiro grupo formado pelas roças originadas da Região Amazônica (Rio Negro, Rio Branco, Rio Solimões, Estado de Mato Grosso e Estado do Pará); o segundo grupo constituído apenas pelas etnovariedades presentes nas roças do litoral do Estado de São Paulo; e o terceiro grupo composto pelas roças coletadas na Região do Xingu. 


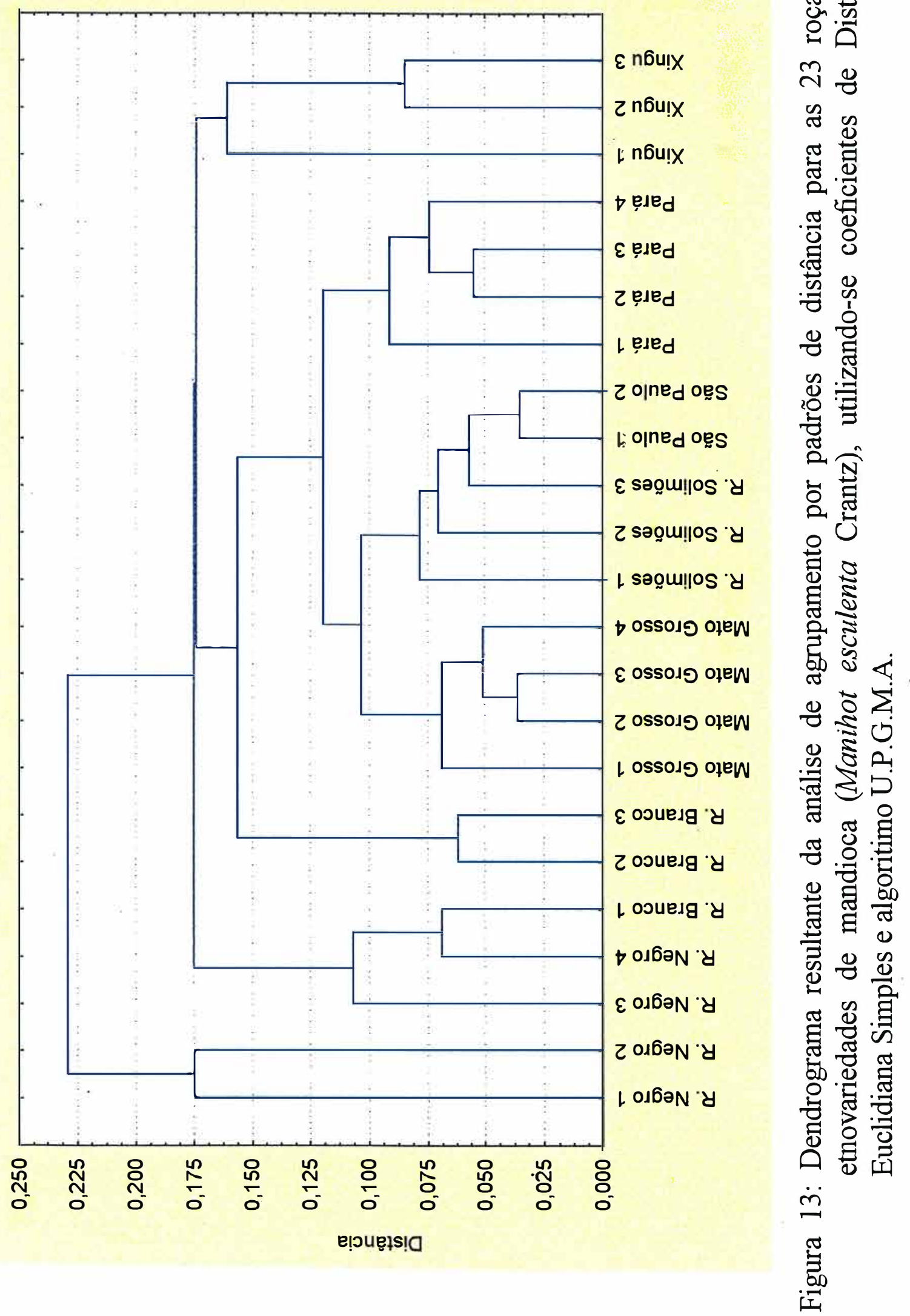




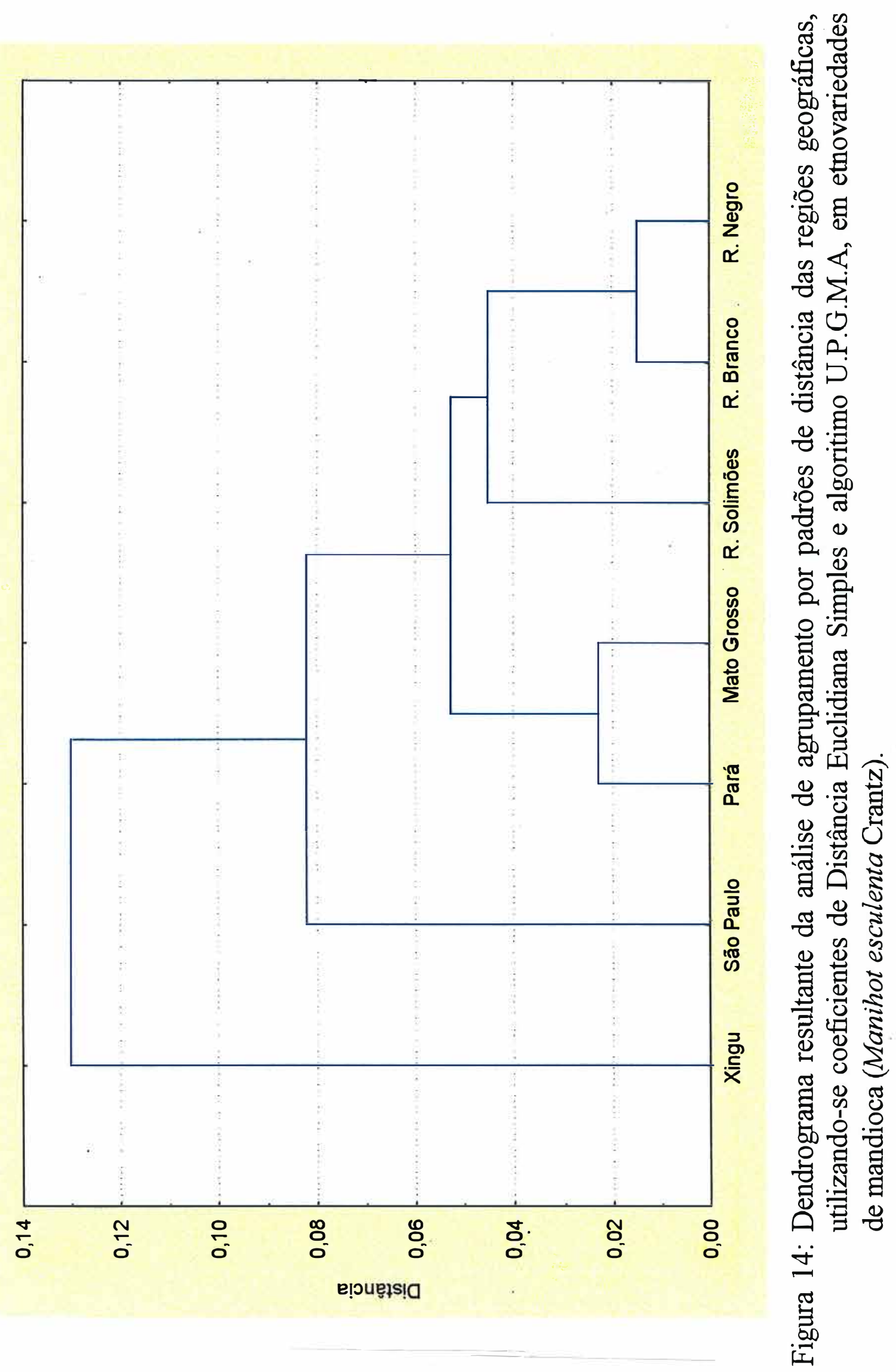


O grupo 1 apresentou grande similaridade, possivelmente por ser formado por etnovariedades coletadas numa área de muito tráfego de pessoas na Região Amazônica, onde ocorre migração de indígenas e caboclos, promovendo intercâmbio de material genético (fluxo gênico de maneira inconsciente) e, consequentemente, tornando as populações mais similares.

No grupo 2, observa-se uma estreita relação entre as etnovariedades do Estado de São Paulo com as da Região Amazônica que constituem o grupo 1, demonstrando afinidade genética e permitindo sugerir que o material cultivado no Estado de São Paulo pode ter sido originado da Região Amazônica. Cury (1998) mostrou que a variedade Mantiqueira (DG137), originada a partir da variedade Santa no litoral norte de São Paulo, ficou mais próxima na dispersão das etnovariedades do Rio Negro e do Rio Solimões do que nas do litoral sul do Estado de São Paulo.

O grupo 3 é constituído por roças que apresentam alto grau de endogamia, possivelmente por se tratar de material que se encontra disperso em uma área muito restrita, principalmente por troca de material entre parentes de tribos vizinhas, e dessa forma facilitando fluxo gênico interno.

\subsection{Análise da Variabilidade Genética, conforme o uso das etnovariedades.}

A intenção dessa análise é promover melhor visualização das relações dos grupos formados e dos genótipos dentro dos mesmos. Além disso, visa a complementariedade da análise de agrupamento, importando a 
estruturação no espaço bi ou tridimensional dos grupos e genótipos baseados nas distâncias entre genótipos dois a dois.

$\mathrm{Na}$ Figura 15, observa-se a apresentação bidimensional considerando-se as duas primeiras coordenadas principais. Na Figura 15, observa-se indícios da formação de dois grupos genéticos: o primeiro formado por etnovariedades utilizadas como mandioca mansa (mesa, macaxeira ou aipim) e o outro grupo correspondente à mandioca utilizada no processamento de farinha (mandioca brava ou maniva).

Os resultados obtidos corroboram o encontrado por Colombo (1997) e Mühlen (1999), que mostra ter sido diferente o processo de domesticação da mandioca de acordo com o uso da cultura pelos povos.

Jennings's (1976) sugere que o ponto central da diversificação evoluvionária da cultura da mandioca, inclui híbridos entre a mandioca cultivada ( $M$. esculenta) e as espécies selvagens. Também afirma que a reprodução sexual, inclusive hibridação interespecífica, apresenta papel de destaque na dinâmica evolutiva durante o processo de domesticação desta cultura, com destaque para a toxicidade de suas raízes (concentração de ácido cianídrico).

Mühlen (1999), trabalhando com três diferentes marcadores de DNA: RAPD, AFLP e microssatélite, também conseguiu separar etnovariedades de mandioca em dois grupos: um constituído pela macaxeira (mandioca doce) e o outro pela mandioca brava.

Experimentos têm sido conduzidos, porém conclusões definitivas não foram apontadas sobre o papel do teor de $\mathrm{HCN}$ no processo de domesticação da mandioca. Os prequisadores se baseiam em observações 


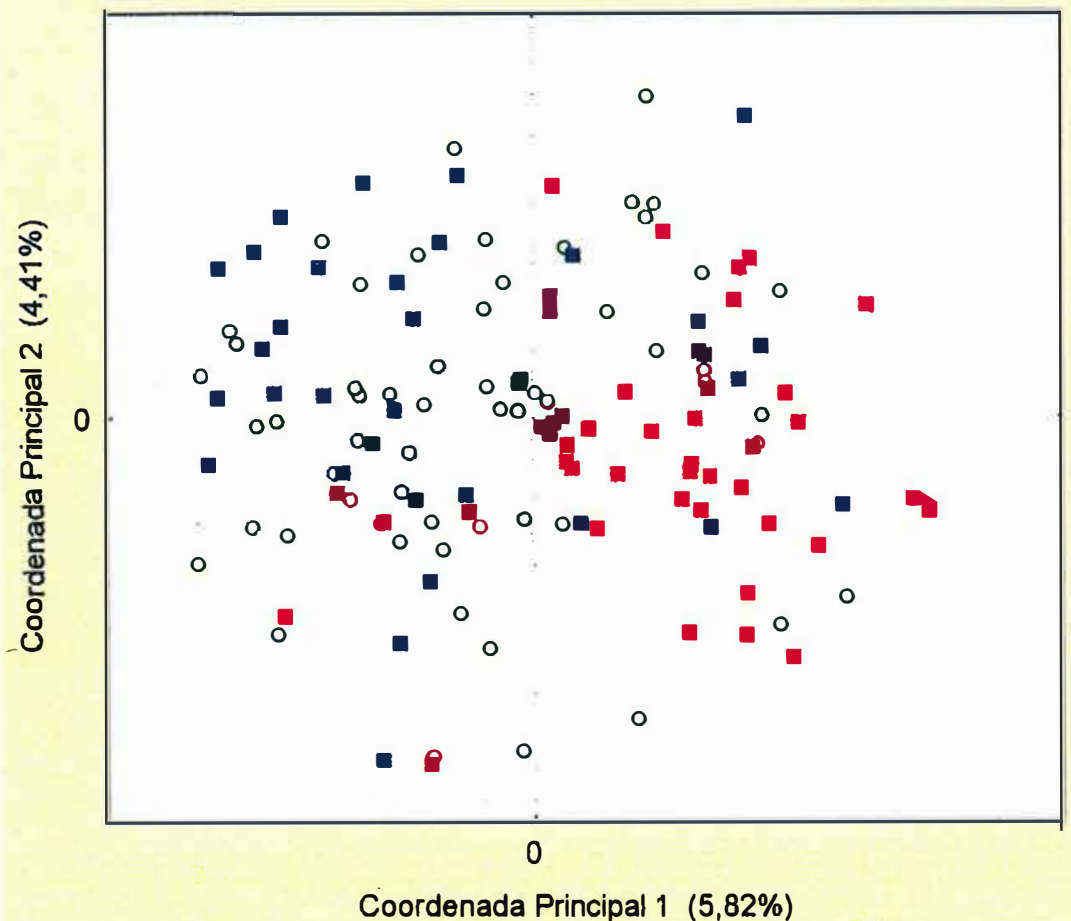

- Uso desconhecido
- Mesa
- Farinha

Coordenada Principal $1 \quad(5,82 \%)$

Figura 15: Escores provenientes da análise de coordenas principais (PCO), calculada a partir das similaridades genética de 139 amostras de etnovariedades de mandioca (Manihot esculenta Crantz), de diferentes regiões geográficas do Brasil. $\mathrm{D}=$ Material de uso desconhecido; $\mathrm{F}$ = Material usado para fabricação de farinha; e $\mathrm{M}=$ Material de Mesa. 
comparativas e não em experimentos controlados. $\mathrm{O}$ papel do glucosídeo cianogênico na resistência à insetos, patógenos e herbívoros também não foi esclarecido. Esta linha de pesquisa necessita maiores esforços, para que pontos básicos como relação do conteúdo de $\mathrm{HCN}$ com seleção durante o processo de domesticação (McKey \& Beckerman, 1993).

Reconstruir as forças seletiva que direcionaram esta evolução é dificil por causa da influência da agricultura indígena que frequentemente alterava suas áreas de plantio. Parece existir uma tendência de selecionar variedades com baixa toxicidade através de práticas de seleção artificial, manipulada pelo homem, quando a mandioca é utilizada na alimentação em contraste com a seleção natural. 


\section{CONCLUSÕES}

$\mathrm{O}$ resultados obtidos, no presente trabalho, permitem obter as seguintes conclusões:

- As etnovariedades detém grande variabilidade genética.

- Os marcadores isoenzimáticos são úteis para a detecção da variabilidade genética das etnovariedades de mandioca em roças de agricultura tradicional.

- A caracterização isoenzimática é recomendada para a avaliação de material genético a ser conservado.

- Ocorre fluxo gênico através de troca de material entre as roças e regiões geográficas pela interferência do homem.

- A variabilidade genética está concentrada dentro de roças e dentro de regiões.

- O grupo de etnovariedades coletado nas roças da Região Amazônica apresentou maior variabilidade genética e o grupo das roças originado da Reserva Indígina do Xingu a menor.

- As coletas de germoplasma de mandioca devem ser feitas considerando as roças como unidades amostrais. 
- A variabilidade genética é mantida e/ou amplificada dentro das populações pela influência dos processos de manejo do homem.

- Existe concordância entre o sistema de Taxonomia "folk" e a caracterização isoenzimática.

- A análise da variabilidade genética através de marcadores isoenzimáticos, mostrou tendência em separar as etnovariedades de mandioca de mesa (macaxeira) e mandioca para fazer farinha. 


\section{REFERÊNCIAS BIBLIOGRÁFICAS}

ALFENAS, A.C.; PETERS, I.; BRUNE, W.; PASSADOR, G.C. Eletroforese de Proteínas e Isoenzimas de Fungos e Essências Florestais. Viçosa, UFV, 1991. 242p.

ALLEM, A.C. Manihot esculenta is a native of the neotropics. Plant Genetic Resources Newsletter, v. 71, p.22-24, 1987.

ALLEM, A.C. A revision of Manihot section Quinquelobae (Euphorbiaceae). Revista Brasileira de Biologia. v. 49, n.1, p.1-26, 1989.

ALLEM, A.C. A new species of Manihot (Euphorbiaceae) from the Brazilian Amazon. International Journal of Plant Sciences, v.160, n.1, p.181-187, 1999.

ALTIERI, M.A. El control ecológico de la biodiversidad en agroecosistemas. Agroecologia y Desarrollo, v. 4, p.2-11, 1992.

AMOROZO, M.C.M. Sistema de agricultura camponesa em Santo Antônio de Leverger, Mato Grosso, Brasil. São Paulo, 1996. 274p. Tese Faculdade de filosofia, letras e ciências humanas, Universidade de São Paulo.

BORSOI FILHO, J.L. Variabilidade isoenzimática e divergência genética de seis cultivares de mandioca (Manihot esculenta Crantz). Viçosa, 1995. 52 p. (Doutorado) - Universidade Federal de Viçosa.

BOSTER, J.S. Classifications, cultivation, and selection of Aguaruna cultivars of Manihot esculenta (Euphorbiaceae). Advances in Economic Botany, v.1, p34-47, 1985. 
BREECHING, J.R.; MARNEY, P. ; GAVALDA, M.A.; NOIROT, M.; HAYSOM, H.R.; HUGHES, M.A.; CHARRIER, A. An assessment of genetic diversity within a collection of cassava (Manihot esculenta Crantz) Germplasm using molecular marker. Annals of Botany, v. 72, p.515-520, 1993.

BREWER, G.L.; SING, C.F. An introduction to isozyme techiniques. New York: Academic Press, 1970. 186p.

BROWN, A.H.D. Isozymes, plant population genetic structure, and genetic conservation. Theoretical and Applied Genetics, v.52, p.145-157, 1978.

BRUSH, S.B. A farmer based approach to conserving crop germplasm. Economic Botany, v.35, n.1, p.70-88, 1981.

BRUSH, S.B. A farmer-based approach to conserving crop germplasm. Economic Botany, v. 45, n.2, p.153-165, 1991.

BRUSH, S.B. Ethnoecology, biodiversity, and modernization in Andean potato agriculture. Journal Ethnobiology, v.12, n.2, p.161-185, 1992.

BRUSH, S.B. In situ conservation of landraces in Centers of Crop Divsesity. Crop Science, v. 35, n.2, p.346-354, 1995.

CARVALHO, C.G.P. Hibridação interespecífica da mandioca (Manihot esculenta Crantz) com espécies afins. Viçosa, 1995. 56p. ("Magister Scientiae") - Universidade Federal de Viçosa.

CARVALHO, L.J.C.B. A mandioca também é nossa. Época, v.5,p.48, 1999.

CHERNELA, J.M. Os cultivares de mandioca na área dos Uapés (Tukâno). In: RIBEIRO, B.G. Suma etnológica brasileira. Petrópolis, Vozes, 1986. p.151-71. 
CLAYTON, J.; TRETIAK, D. Amine-citrate buffers for $\mathrm{pH}$ control in starch gel electrophoresis. J. Fisheries Res.Board Can., v. 29, p.1169-1172, 1972.

CLEMENT, C.R.; KERR, W.E. Práticas agrícolas de conseqüências genéticas que possibilitaram aos índios da Amazônia uma melhor adaptação às condições ecológicas da região. Acta Amazônica, v.10, n.2, p.251-261, 1980.

CLEVELAND, D.A.; SOLERI, D. ; SMITH, E.S. Do folk crop varieties have a role in Sustainable Agriculture? BioScience, v. 44, n.11, p.740$751,1994$.

COLOMBO, C.A. Étude de la diversité génétique de maniocs américains (Manihot esculenta Crantz) par les marqueurs moléculaires (RAPD et AFLP). Montpellier, 1997. 145p. Thèse (Doctorat) - École Nationale Superieure Agronomique de Montpellier.

CONCEIÇÃO, A.J. Mandioca. 3.ed. São Paulo: Nobel, 1987. 382p.

CRUZ, N.D. Citologia do gênero Manihot Adams. I. Determinação do número de cromossomos em algumas espécies. Anais da Academia Brasileira de Ciências. v. 40, n.1, p. 91-95, 1968.

CURI, P.R. Metodologia da Pesquisa Científica. Botucatu, FMVZ, 1991. 259 p.

CURY, R. Dinâmica evolutiva e caracterização de germoplasma de mandioca (Manihot esculenta Crantz), na agricultura autóctone do Sul do Estado de São Paulo. Piracicaba, 1993. 103p. (Mestrado) - Escola Superior de Agricultura "Luis de Queiroz", Universidade de São Paulo.

CURY, R. Distribuição da diversidade genética e correlações de caracteres em etnovariedades de mandioca (Manihot esculenta, Crantz) provenientes da agricultura tradicional do Brasil. Piracicaba, 1998. 163p. (Doutorado) - Escola Superior de Agricultura "Luiz de Queiroz", Universidade de São Paulo. 
DOMINGUEZ, C.E.; CEBALLOS, L.F.; FUENTES, C. Morfologia de la planta de yuca. In: DOMINGUEZ, C.E. Yuca: Investigation, production y utilization. Cali: CIAT, 1984. p.29-49.

FARALDO, M.I.F. Caracterização isoenzimática e diversidade de etnovariedades de mandioca (Manihot esculentas Crantz). Piracicaba, 1994. 91p. Doutorado Escola Superior de Agricultura "Luiz de Queiroz", Universidade de São Paulo.

FERRAZ, E.M.; GANDARA, F.B.; CUNHA, N.L.; REIS, M.S.; KAGEYAMA, P.Y. Eletroforese de isoenzimas para espécies arbóreas - Manual de Laboratório (Versão 1994). Piracicaba, ESALQ / Departamento de Ciências Florestais / Laboratório de Biologia Reprodutiva e Genética de Espécies Arbóreas. 1994. 23p.

FRANKEL, O.H.; BROWN, A.H.D.; BURDON, J.J. The conservation of plant biodiversity. United Kindom, 1998. 299p.

FUTUYMA, D.J. Biologia evolutiva. 2.ed. Ribeirão Preto: SBG, 1992. $631 \mathrm{p}$.

GAIFAMI, A.; CORDEIRO, A. Cultivando a diversidade: Recursos Genéticos e segurança alimentar local. Rio de Janeiro: AS-PTA, 1994. 205p.

GRANER, E.A. Contribuição para o estudo citológico da mandioca. Piracicaba, ESALQ/Departamento de Genética, 1935. 28p.

GRATTAPAGLIA, D.; NASSAR, M.A.; DIANESE, J.C. Biossistemática de espécies brasileiras do gênero Manihot baseada em padrões de proteína da semente. Ciência e Cultura, v. 39, n.3, p294-300, 1987.

GULICK, P.; HERSHEY, C.; ALCAZAR, E. Genetic Resources of cassava and wild relatives. AGPG:IBPGR/82/111, Rome, 1983. p.56. 
HAMRICK, J.L. Isozymes and analysis of genetic structure in plants populations. In: SOLTIS, D.E. \& SOLTIS, P.S., ed. Isozyme in Plant Biology. Portland. Dioscorides Press, 1985. p. 87-105.

HAMRICK, J.L.; GODT, M.J.W. Allozyme diversity in plant species. In: SOLTIS, D.E.; SOLTIS, P.S. Isozymes in plant biology. Portland: Discorides Press, 1989. p.43-63.

HARLAN, J.R.; DE WET, M.J. Toward a rational classification of cultivated plants. Taxon. v. 20, n.4, p.509-517, 1971.

HARLAN, J.R. Crops and Man. Madison, ASA, 1975. p.295.

HERSHEY, C. H. Manihot esculenta diversity. In: International Network for cassava genetic resouces. Colômbia, 1992. p.111-134.

HERSHEY, C.; AMAYA, A. Germoplasma de yuca: Evolución, distribución y colección. In: DOMINGUEZ, C.E. Yuca: investigación, produción y utilzación. Cali, CIAT, 1989. p. 77-79.

HILLIS, D.M.; MORITZ, C.; MABLE, B.K. Molecular Systematics. 2 ed. Suderland, 1996. 655p.

HUSSAIN, A.; BUSHUK, W.; RAMIREZ, H.; ROCA, W. Identification of cassava (Manihot esculenta Crantz) cultivars by electrophoretic patterns of esterase isozymes. Seed Science \& Technology. v. 15, p.19-22, 1987.

JAIN, S.K. Population management in new plant breeding approaches. In: JAIN, S.K. \& BOTSFORD, L.W., eds. Applied population biology. Kluwer Academic Dorchecht Publishers. 1992. p.

JENNINGS, D.L. Manihot melanobasis Müll-Arg. - a useful parent for cassava breeding. Euphytica. v. 8, p.157-163, 1959.

JENNING, D.L. Cassava. In: SIMMONDS, N.W. Evolution of crop Plants. London, Longman, 1979. p. 81-4. 
KEPHART, S.R. Starch gel electrophoresis of plant isozymes: a comparative analysis of techniques. American Journal of Botany. $\mathrm{v}$. 77, n.5, p.693-712, 1990.

KERR, W.E.; POSEY, D.A. Infornações adicionais sobre a agricultura dos Kayapós. Interciência, v.9, n.6, p.392-397, 1984.

LEFÈVRE, F. \& CHARRIER, A. Heredity of seventeen isozyme loci in cassava (Manihot esculenta Crantz). Euphytica, v. 66, n.3, p.171-8, 1993a.

LEFĖVRE, F. \& CHARRIER, A. Isozymes diversity within Africa Manihot germplasm. Euphytica, v.66, n.1/2, p73-80, 1993 b.

LUDWING, J.A.; REYNOLDS, J.F. Statistical ecology. John Wiley \& Sons, N.Y. 1988. 337p.

McMILLIN, D.E. Plant Isozymes: A historical perspective. In: TANKSLEY, D.S. \& ORTON, T.J. Isozyme in plant genetic and breeding. , Amsterdam, Elsevier, 1983. pt. A, p. 3-13.

MARCON, G. Estrutura genética de populações de Stylosanthes humilis H.B.K. (Leguminosae) de três regiões ecogeográficas do Estado de Pernambuco. Piracicaba, 1988. 179 p. (Doutorado) - Escola Superior de Agricultura "Luiz de Queiroz", Universidade de São Paulo.

MARTINS, P.S. Biodiversity and agriculture: patterns of domestication of brazilian native plants species. Anais da Academia Brasileira de Ciências, v. 66, Supl.1, p.219-226, 1994.

MILLAR, C.I. The Californian closed cone pinus (subsection Oocarpae little and Critchfield): a taxonomic history and review. Taxon, v. 35, n.4: p.647-656, 1986. 
MORISHIMA, H.; MARTINS, P.S. Investigation of plant genetic resources in the Amazon basin with the emphasis on the genus Oryza. The Manbusho International Scientific Research Program, Mishima, Japan, 1994. 100p.

MÜHLEN, G.S. Avaliação da diversidade genética de etnovariedades de mandioca (Manihot esculenta Crantz) com marcadores de DNA: RAPD, AFLP e microssatélites. Piracicaba, 1999. 176 p. Tese (Doutorado) Escola Superior de Agricultura "Luiz de Queiroz", Universidade de São Paulo.

NEI, M. Analysis of gene diversity in subdivided populations. Proceedings of the National Academy of Sciences of the United States of America, v. 70, n.12, p.3321-3323, 1973.

NEI, M. Estimation of averege heterozygosity and genetic distance from a small number of individuals. Genetics, v. 89, p. 583-590, 1978.

NEVO, E.; ZOHAY, D.; BROWN, A.H.D.; HABER, M. Genetic diversity and environmental associations of wild barley, Hordeum spontaneum, in Israel. Evolution, v.33, p.815-833, 1979.

NODA, H.; YUYAMA, K. General aspects of hydrology and climatology of the Amazonian Basin. In: MORISHIMA, H. \& MARTINS, P.S. Investigation of plant genetic resources in the Amazon basin with the emphasis on the genus Oryza. The Manbusho International Scientific Research Program, Mishima, Japan, 1994. p.6-9.

NYE, M.M. The mis-measure of manioc (Manihot esculenta Euphorbiaceae). Economic Botany, v.45, n. 1, p.47-57, 1991.

PERONI, N.; MARTINS, P.S. Bidiversidade e dinâmica evolutiva de espécies cultivadas em roças de agricultura tradicional em áreas de Mata Atlântica. In: CONGRESSO NACIONAL DE BOTÂNICA, 46., Ribeirão Preto, 1995. Resumos. FFCLRP/Universidade de São Paulo: Sociedade Botânica do Brasil, 1995. p.204. 
PERONI, N. Taxonomia folk e diversidade intra-específica de mandioca (Manihot esculenta Crantz) em roças de agricultura tradicional em áreas de Mata Atlântica do sul do Estado de São Paulo. Piracicaba, 1998. 191p. Dissertação (Mestrado) - Escola Superior de Agricultura "Luiz de Queiroz", Universidade de São Paulo.

PIMENTEL, D. ; STACHOW, U.; TAKACS, D.A.; BRUBAKER, H.W.; DUMAS, A.R.; MEANEY, J.J.; O ONEAL, J.A.S.; ONSI, D.E.; CORZILIUS, D.B. Conserving biological diversity in agricultural/forestry systems. BioScience, v.42, p.354-362, 1992.

PERRY, B.A. Chromosome number and phylogenetic relationship in the Euphorbiaceae. American Journal of Botany, v.30, p.527-543, 1943.

PLUCKNETT, D.I. International agriculture research for the next century. BioScience, v.43, p.432-40, 1993.

QUIROS, C.P.S.B.; BRUSH, D.S.; DOUCHES, K.; ZIMMERER, S.; HUESTIS, G. Biochemical and folk assessment of variability of Andean cultivated potatoes. Economic Botany, v.44, n.2, p.254-266, 1990.

RAMIREZ, H.; HUSSAIN, A.; ROCA, W.; BUSHUK, W. Isozyme electrophoregrams of sixteen enzymes in five tissues of Cassava (Manihot esculenta Crantz) varieties. Euphytica, v.36, n.1, p.39-48, 1987.

RENVOIZE, B.S. The area of origin of Manihot esculenta as a crop plant a review of the evidence. Economic Botany, v.26, p.352-360, 1973.

ROGERS, D.J. Some botanical and ethnological considerations of Manihot esculenta. Economic Botany, v. 19, p.369-377, 1965.

ROGERS, D.J. Some further considerations on the origin of Manihot esculenta Crantz. Tropical Root and Tuber Crops Newsletter, v. 6, p.4-14, 1972. 
ROGERS, D.J.; APPAN, S.G. Manihot and manihotoides

(Euphorbiacea). Flora Neotropica. Monograph., 1973, n.13. 272p.

ROLHF, F.J. Numerical Taxonomy and Multivariate Analysis System. New York, Extern Publishing, 1988. 110 p.

SALICK, J. Crop domestication and evolutionary ecology of cocona (Solanum sessiliflorum Dunal). In: HEICHT, M.K. et al. (Ed.) Evolutionary biology. New York: Plenum Press, 1992. p. 247-285.

SALICK, J. Toward an integration of evolutionary ecology and economic botany: personal perspectives on plant/people interations. Annals of the Missouri Botanical Garden, v.82, p.25-33, 1995.

SALICK, J.; CELLINESE, N.; KNAPP, S. Indigenous diversity of cassava: generation, maintainance, use and loss among Amuesha, peruvian upper Amazon. Economic Botany, v. 51, n.1, p.6-19, 1997.

SAMBATTI, J.B.M. Erosão genética e conservação de germoplasma de mandioca na agricultura autóctone em Ubatuba-SP. Piracicaba, 1998. 165p. Dissertação (Mestrado) - Escola Superior de Agricultura "Luiz de Queiroz", Universidade de São Paulo.

SANTOS, E.G. Ecologia da polinização, fluxo de pólen e taxa de cruzamento em Bauhinia forficata Link. (Caesaloiniaceae). Piracicaba, 1994. 114p. Dissertação (Mestrado) - Escola Superior de Agricultura "Luiz de Queiroz", Universidade de São Paulo.

SCANDALIOS, J.G. Genetic control of multiple molecular forms of enzymes in plants. Biochemical Genetics, v. 3, p.37-79, 1969.

SILVA JARDIM, J.R. Hibridação interespecífica no gênero Manihot Adams. Viçosa, 1984. 74 p. Dissertação (Mestrado) - Universidade Federal de Viçosa. 
SILVA, R.M. Dinâmica alélica em roças de etnovariedades de mandioca (Manihot esculenta Crantz). Piracicaba, 1999. (Doutorado) - Escola Superior de Agricultura "Luiz de Queiroz", Universidade de São Paulo. (no prelo)

SIMON, C.; ARCHIE, J. An empirical demonstration of the lability of heterozygosity estimates. Evolution, v.39, n.2, p.463-467, 1985.

SMITHIES, O. Zone electrophoresis in starch gels. Biochemical Journal, v. 61, p.629, 1955.

SNEATH, P.H.A.; SOKAL, R.R. Numerical Taxonomy. San Francisco, W.H. Freeman, 1973. 573 p.

SOLERI, D.; CLEVELAND, D.A. Hopi crop diversity and change. Journal of Ethnobiology, v. 13, n.2, p.203-231, 1993.

SOLTIS, D.E.; HAUFLER, C.H.; DARROW, D.C.; GASTONY, G.J. Starch gel electrophoresis of ferns: a compilation of grinding buffers, gel and electrode buffers, and staining schedules. American Fern Journal, v. 73, n.1, p.9-26, 1983.

STATSOFT INCO. Statistica for Windows: Computer Program Manual. Tulsa: StatSoft Inco., 1996.

STOREY, H.H.; NICHOLS, F.W. Studies of mosaic of cassava. Annals of Applied Biology, v.25, p.790-806, 1938.

SWOFFORD, D.L.; SELANDER, R.B. Biosys-1. A computer program for the analysis of allelic variation in population genetics and biochemical systematics. Release 1,7, David L. Swofford, Illinois Natural History Survey All Rights Reserved, Illinois, 1989.

TORGGLER, M.G.F.; CONTEL, E.P.B.; TORGGLER, S.P. Isoenzimas: variabilidade genética em plantas. Ribeirào Preto: Sociedade Brasileira de Genética, 1995. 186p. 
UGENT, D.; POZORSKI, S.; POZORSKI, T. Archaeological manioc (Manihot) from Coastal Peru. Economic Botany, v. 40, p.78-102, 1986.

UMANAH, E.E.; HARTMANN, R.W. Chromosome numbers and karyotypes of some Manihot species. Journal American Society Horticultural Science, v. 98, n.3, p272-274, 1973.

WEIR, B.S. Genetic data analysis II. Methods for discrete population genetic data. 2.ed. Sunderland: Sinaver Associates, 1996. 445p.

WENDEL, J.F.; WEEDEN, N.F. Visualization and interpretation of plant isozymes. In: SOLTIS, D.E.; SOLTIS, P.S. (Ed.) Isozymes in plant biology. London: Chapman and Hall, 1990. cap. 1, p.5-45.

WOLDA, H. Similarity indices, sample size and diversity. Oecologia, v. 50, p.296-302, 1981.

WRIGHT, S. The interpretation of populations structure by F-statistics with special regard to systems of mating. Evolution, v.19, p.395-420, 1965.

ZEVEN, A.C. A review of definitions and classifications. Euphytica, v. 104, n.2, p. 127-139, 1998. 